\title{
Ovoid amphorae as the first Roman provincial repertoire in Hispania Ulterior (the Guadalquivir valley)
}

\author{
Enrique García Vargas \\ Departamento de Prehistoria y Arqueología \\ Universidad de Sevilla, Facultad de Geografía e História \\ egarcia@us.es \\ Horacio González Cesteros \\ Austrian Archaeological Institute \\ horacio.gonzalez@oeai.at \\ Rui Roberto de Almeida \\ UNIARQ - Centro de Arqueologia da Universidade de Lisboa. Faculdade de Letras \\ Câmara Municipal de Loulé, Museu Municipal de Loulé \\ rui.dealmeida@gmail.com
}

\begin{abstract}
During the first century $\mathrm{BC}$, the Guadalquivir valley joins the group of those producing ovoid amphorae in the Western Mediterranean, as it becomes one of the main exporting areas of agricultural commodities. This development took shape in the Augustan period and later, due to correlation between the necessities demanded by the State and the ability of the southern Hispanic territories to supply them. However, this process takes its first steps even earlier; from the early moments of the first century BC, the Guadalquivir valley apparently began a mass-production of agricultural goods, as is reflected in the amphora repertoire of Ulterior being then produced as the first Romanised provincial amphorae of the region. This article presents the most important ovoid forms produced in the Guadalquivir valley, paying particular attention to their form and their epigraphical features, as well as investigating their distribution in internal and external markets. Some other questions are treated too: the documented production places; the evolution of these products into a standardised format that closely follows the path of the transformation of the Guadalquivir valley into a highly specialised agricultural territory, based on olive-oil manufacture, just as would be case for the economy of the region during early Imperial times.
\end{abstract}

Key words: Hispania Ulterior; Guadalquivir valley; amphora production; Hispanic ovoid amphorae; agricultural expansion and exportation.

Resumen: El valle del Guadalquivir se une a la dinámica de producción de ánforas ovoides del Mediterráneo occidental a lo largo del siglo I a.C., convirtiéndose en uno de los principales focos de exportación de bienes agropecuarios. Esta tendencia cristaliza desde época de Augusto debido al vínculo que se establece entre las necesidades de abastecimiento estatales y la capacidad de satisfacer dichas necesidades mediante los suministros del sur de Hispania, pero es un proceso que tiene sus raíces en momentos anteriores, cuando el valle del Guadalquivir comienza a producir a gran escala y cuando empieza a fraguar el primer repertorio de ánforas propias de la provincia romana. En este artículo se van a presentar los principales tipos de ánforas ovoides producidos en el Guadalquivir, con particular atención a sus características formales, epigráficas y a su difusión. Igualmente, cuestiones como la documentación de los lugares de producción y el tránsito hacia la regularización de la estandarización formal y la especialización en la producción de aceite de oliva, que será una de las claves de la potencia económica de la posterior Bética altoimperial, van a ser abordadas en las siguientes páginas.

Palavras clave: Hispania Ulterior; valle del Guadalquivir; producción de ánforas; ánforas ovoides hispanas; expansión agrícola y exportación.

\section{Introduction}

In the absence of detailed research and finds from the production areas of the late Republican period, it is to the contexts of their consumption in the Western Mediterranean and the Atlantic area of the Iberian Peninsula beyond the Strait of Gibraltar, that one must have recourse in order to recover the clearest archaeological evidence for the emergence in the markets of a new category of South-Hispanic amphorae, those that have received the generic name of the Ovoid amphorae of the Guadalquivir. This term actually comprises a set of these vessels: they display a great morphological range and with such varying details in the make-up of their bodies to the extent that their basic unity of type is not always clear. Recent work, though, has made considerable progress in defining the morphology and chronology of this family of containers (Fabião 2001; Almeida 2008; García Vargas 2010; García Vargas, Almeida and González Cesteros 2011; González Cesteros, García Vargas and Almeida 2018).

The Ovoid amphorae of the Guadalquivir appeared when the already large family of Mediterranean ovoid amphorae had reached a relatively late stage in their development: the central third of the 1st century $\mathrm{BC}$ (Miró i Canals 2016; Miró i Canals and Járrega Domínguez in this volume) and shortly before the Lusitanian ones 


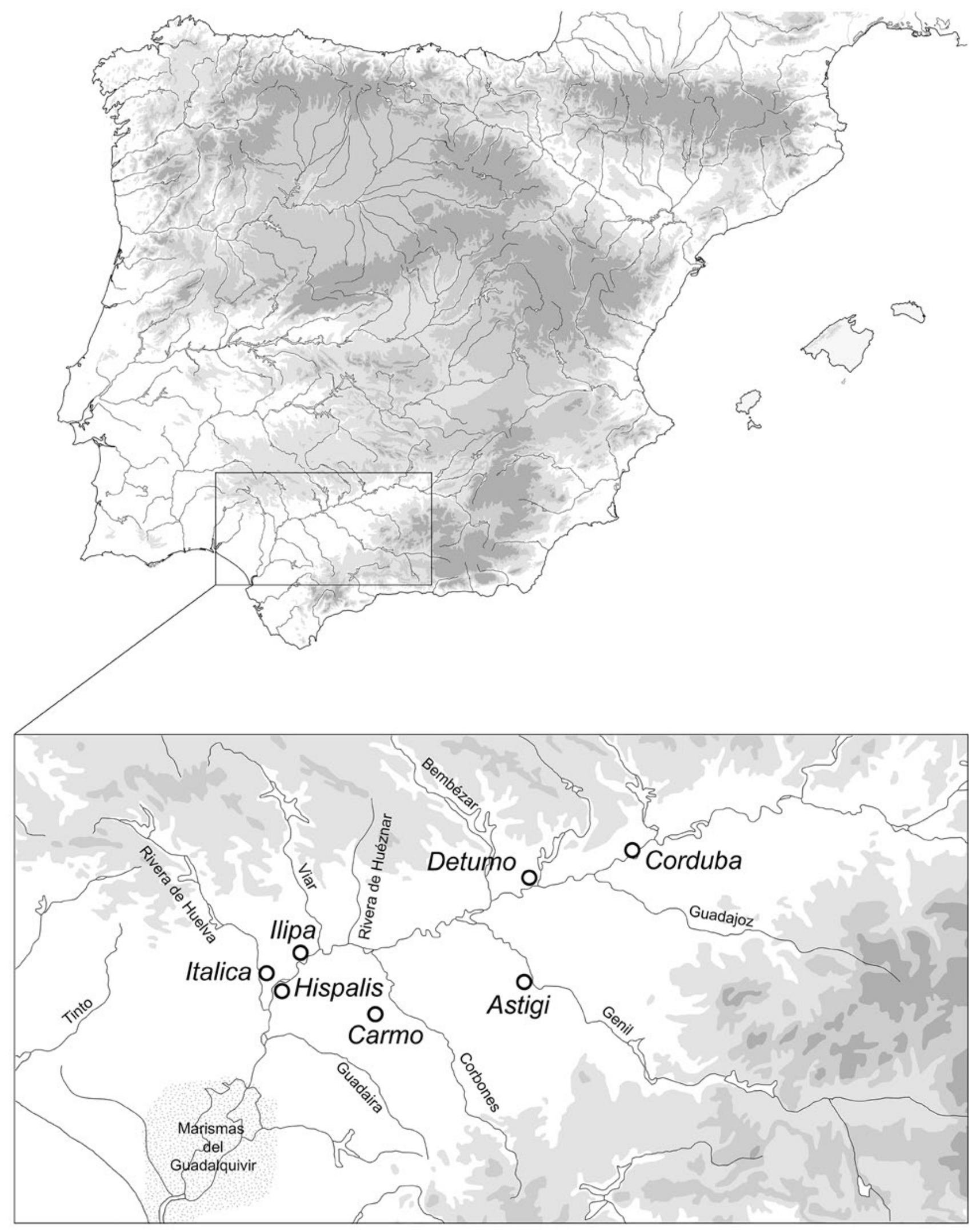

Figure 1. MAP of the IBERIAN PENINSULA, WITH DETAIL FROM the GUAdALQUiVIR VALLEY, AND MAIN URBAN CENTRES DURING 1ST CENTURY BC. 
(García Vargas, Almeida and González Cesteros 2011; González Cesteros, García Vargas and Almeida 2018) entered the scene. They thus appear during the last stage of the long history of the Republican ovoids, whose oldest forms (Italian and African) got under way practically a century earlier (Manacorda in this volume; Contino and Capelli in this volume). It is not, therefore, unreasonable to consider them as interpretations (vide infra) of a foreign type that emerged suddenly into a cultural and artisanal setting already dominated by other amphora types.

\section{Previous products and first Roman imitations in the Guadalquivir valley}

The typological framework of Roman amphorae in the interior of the Guadalquivir valley prior to the irruption of the ovoid types in the central third of the 1st century BC was already relatively complex: it included amphorae derived from Turdetan productions, generically called Pellicer D, with distant origins in the Semitic repertoire of the Early Iron Age (Ferrer Albelda and García Fernandez 2008; García Vargas 2016); imitations of central-Mediterranean containers of the well-known 'Greco-Italian' tradition, the Dressel 1 (García Vargas 2012; Bernal Casasola et al. 2013; Almeida, García Vargas and González Cesteros 2016), and imitations of late Punic forms from the provincial coast, the T-4.3.3. (Ramon Torres 1995; Sáez Romero 2008: 565-572; García Vargas, Almeida and González Cesteros 2011: 198-200; Sáez Romero et al. 2016).

\subsection{Pellicer D}

Pellicer D amphorae are the last representatives of the large and complex family of Turdetan amphorae, once called 'Ibero-Punic' (Pellicer Catalán 1978; Pellicer Catalán, Escacena Carrasco and Bendala Galán 1983). These had evolved from the oldest Phoenician forms, through the so-called Pellicer B-C type, which they seem to replace in the second half of the 3 rd century $B C$.

Pellicer D is an amphora with a tubular or cylindrical body, and no neck, with an inturning rim otherwise undifferentiated from the wall of the body, except for a slight line or external protrusion, that tends to disappear from the end of the 2nd century BC. The internal thickening of the rim that characterises the oldest productions of the type also tends to vanish, with undifferentiated and rounded rims thereafter predominating, although almost until the end of its operative life, the Pellicer D will present several types of rims.

The morphology of the amphora remains unchanged in its main aspects throughout its entire production, with the exception of some variants of late specimens, such as those known as Castro Marim 1 - named from the settlement in the Portuguese Algarve where they were first identified and catalogued (Arruda et al. 2006). These present a strong carination of the wall in the upper third of the body, which in some specimens practically reaches a right angle, remaining nigh horizontal up to the rim: this gives the upper part of the amphora a very distinct morphology (Arruda et al. 2006: 163; Bargão and Arruda 2014: 145-148). The differences between Castro Marim 1 and Pellicer D, as far as the upper third of the amphora is concerned, are so notable that it has been proposed that they be considered as two different types ( Bargão and Arruda 2014).

The rest of the morphological elements that contribute to a typological diagnosis seem to be very similar, if not identical, in almost all productions: 'Punic'-type 'ear handles', rounded shoulders and bases that are a simple button at the culmination of an ogival-profiled base, although an 'omphalos'-type bottom profile is argued for in the case of Castro Marim 1 ( Bargão and Arruda 2014: 147, fig. 5 no. 4).

Although the initial dating for the form is quite complicated to work out in the current state of research (4th century BC? 3rd century BC?), the end of its life seems to have taken place more or less suddenly, somewhere around the very start of the Augustan period. This is suggested by the date of the pottery workshop discovered at the plot of Dr Fleming 13-15, in Carmona (Seville), where it is produced next to Haltern 70 (García Vargas 2012).

This coexistence between Turdetan types and other clearly Romanised forms is one of the most surprising outcomes of recent research on the Guadalquivir. This is a phenomenon that affects not only amphorae, but also common ware ceramics, since the repertoires of painted and plain ceramics produced, for example, in Carmo/ Carmona (Seville) or in Ilipa Magna/Alcalá del Río (Seville) continue to reproduce the forms and decorations typical of pre-Roman times. However, they already include some types derived from the Hellenistic-Roman shape range, not to mention imitations of Campanian black-gloss pottery or relatively early sigillatas in the region (García Fernández and García Vargas 2014).

\subsection{Dressel 1}

The existence of a group of amphorae that, in their generic character, can be included under the name of Dressel 1 from the Guadalquivir was formerly proposed for the first time by C. Fabião (1989: 179; 2001: 667). Before then there had already been pointed out, albeit in a superficial way, the identification of a series of specimens of Dressel $1 \mathrm{~B}$ and $\mathrm{C}$ with fabrics of the Guadalquivir group (Molina Vidal 1997). However, it was not until the publication of the materials from the settlement of La Loba (Benquet and Olmer 2002) that their definite existence was proven.

In general, the 'provincial imitations' of 'Dressel 1' are to be seen quite a bit earlier than the Ovoid amphorae from 

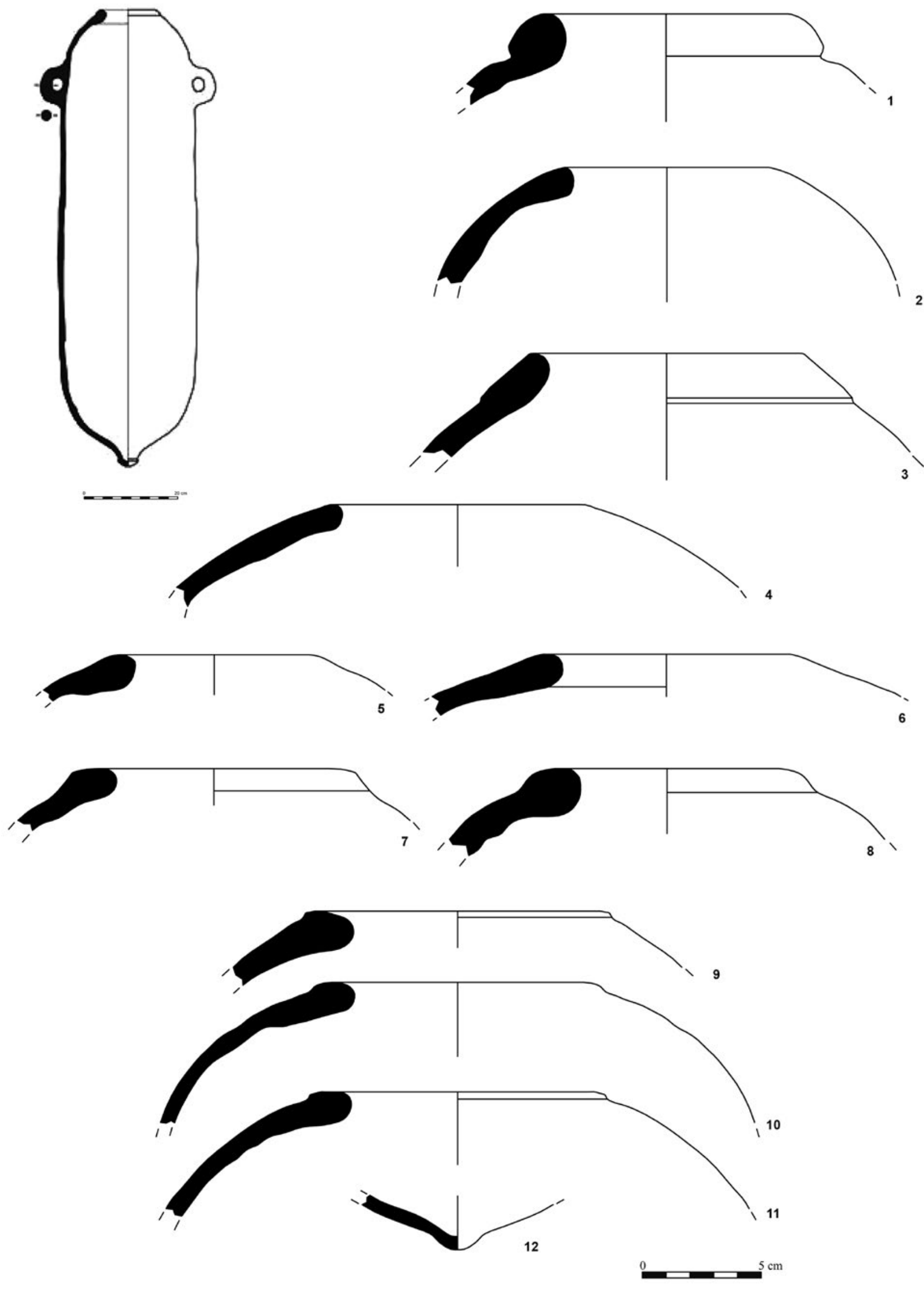

Figure 2. Pellicer D. Prototype and fragments produced in the Guadalquivir valley. 1-2: Alcázar of SeVille, Phase I; 3-5: Alcázar of Seville, Phase II; 6: Seville, Calle Alemanes No. 7-9; 7-12: Carmona, Dr. Fleming Street No. 13-15. 


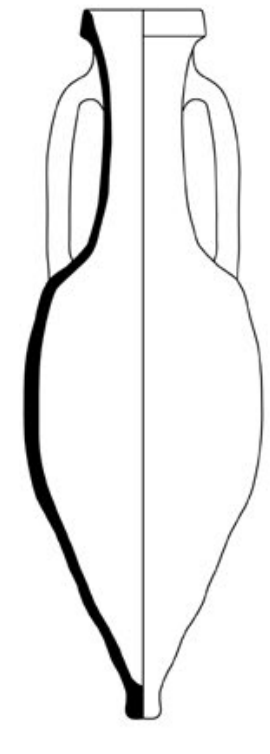

La Loba

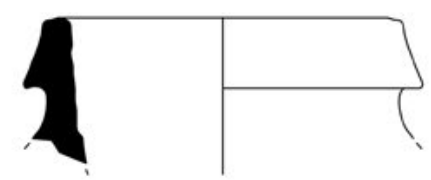

Patio de Banderas, Seville. Phase I
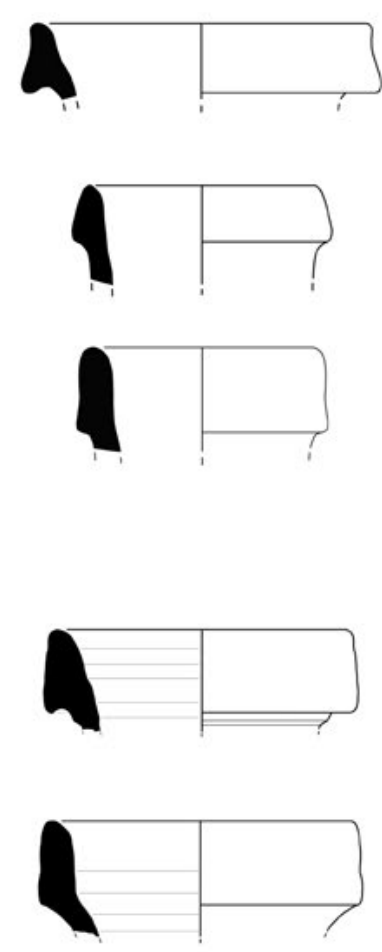
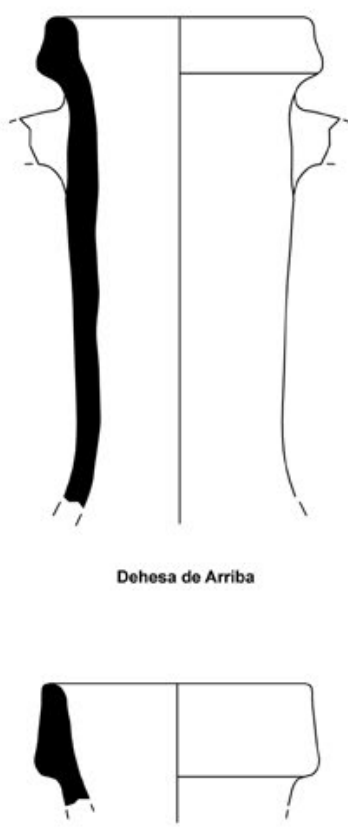

Patio de Banderas, Seville. Phase I

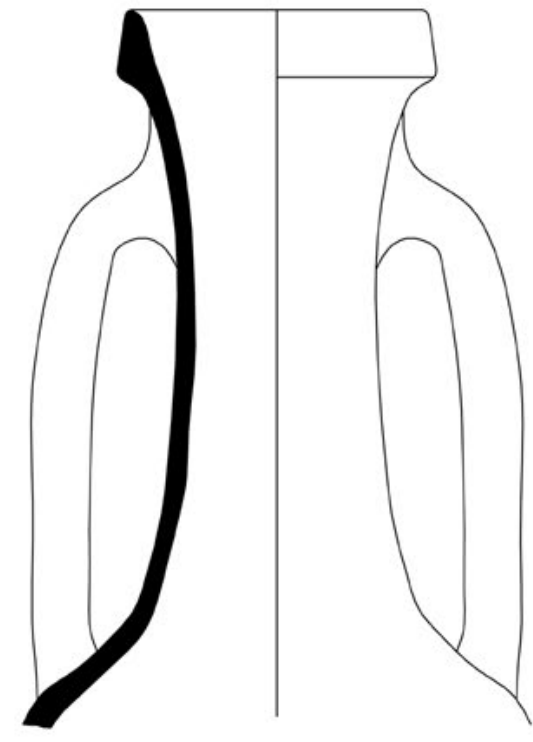

La Loba: detail talica
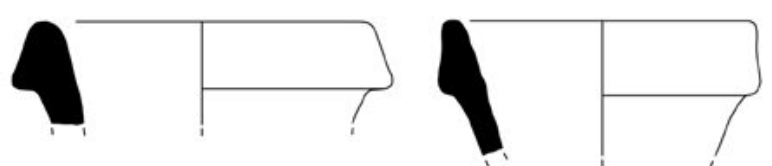

Faro
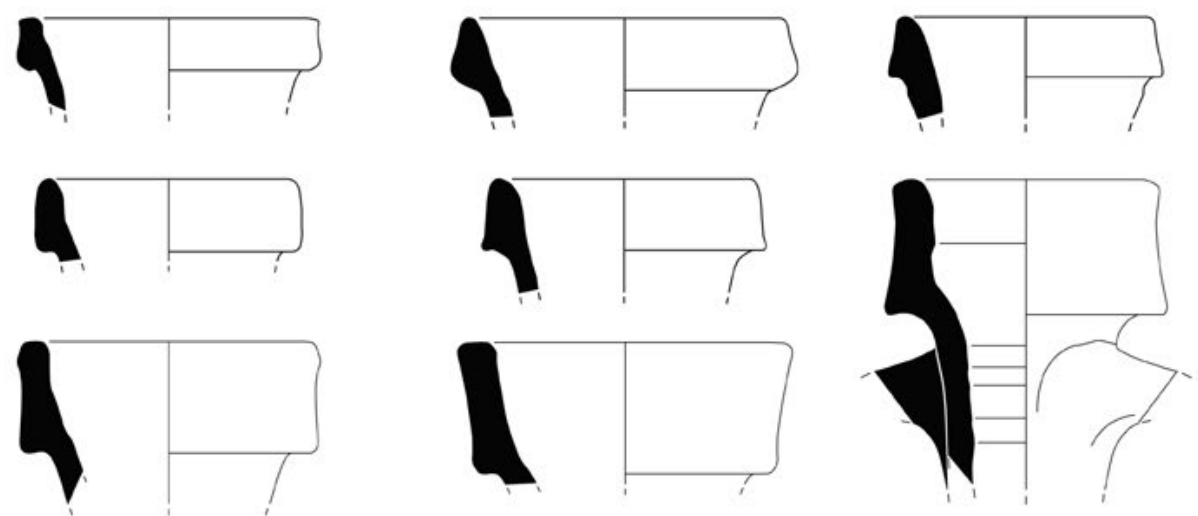

Mesas do Castelinho
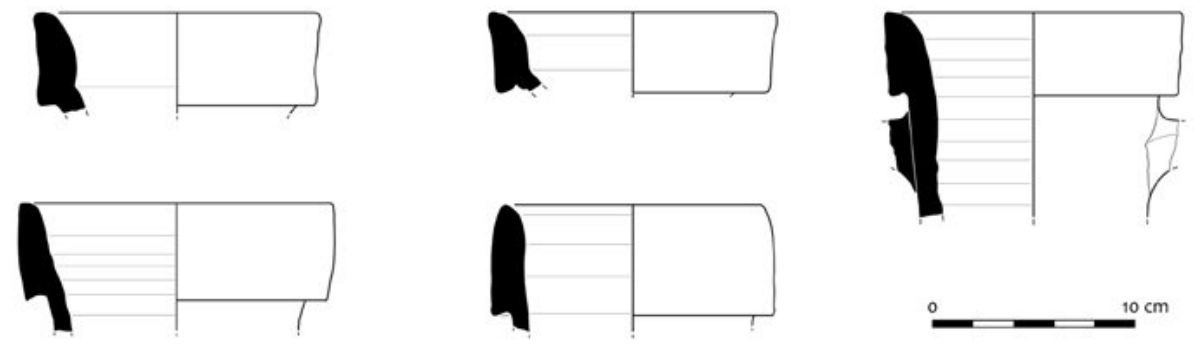

Figure 3. Dressel 1. Prototype ANd fRAgments Produced in the Guadalquivir VAlley. 
the Guadalquivir, appearing from the first beginnings of Hispanic amphora production in a Romanised environment, defined by C. Fabião as the 'reproduction of italic containers' phase (Fabião 2001: 666). For some time they coexisted, as is certified by the amphora deposit of Italica (Seville) (García Vargas, Almeida and Fabião forthcoming) which must be dated around the middle of the 1st century BC. The oldest known contexts for Dressel 1 in Ulterior are those of La Loba (vide supra), a mining settlement in the Sierra Morena (Cordova) (Blázquez Martínez, Domergue and Sillieres 2002) dated to between 110 and $90 \mathrm{BC}$. Here, the food supply is dominated by the Italian Dressel 1C (Benquet and Olmer 2002), but the Dressel 1 from Hispania Ulterior are already there in significant numbers.

The few specimens known until now that are representative of these products typical of the Guadalquivir valley lack any thorough standardisation of output, which is why they usually present odd and unique details in their form. The presence of isolated fragments indeed raises many doubts as to their formal ascription, but by combining all the diagnostic elements (rims, handles, bodies and spikes), as in the case of the La Loba specimens, it is certain that one is confronted by with copies of Dressel 1, whose range of variability and difference from the Italic prototypes is sometimes striking. ${ }^{1}$

As to the different regions, contexts and chronologies of its distribution, three large geographical areas stand out. The first comprises the immediate surroundings of the Guadalquivir valley itself, in settlements related to mining and/or commercial activities - embracing La Loba, Dehesa de Arribas and the city of Munigua - and in nuclei of commercial importance such as Hispalis; in dates that cluster within the first half of the 1st century BC. The second locale, in southern contexts and in the southeastern quadrant of Ulterior is of a similar nature (Molina Vidal 1997; Mateo Corredor 2016; Mateo Corredor and Mayorga Mayorga 2017). The third, and currently the most numerous, is the western Atlantic coast and its most immediate hinterland, in urban contexts of a pre-Roman origin or with presumable military connotations; these may date to the first half of the 1st century BC, as seems to be the case of Mértola (Almeida 2008: 64) and Cerro do Cavaco (Tavira). However, here on the western façade of the Iberian Peninsula, they are mostly somewhat later, from the second half of the 1st century $\mathrm{BC}$, such as Scallabis/Santarém (Almeida 2008), Mesas do Castelinho (Parreira 2009) and Ossonoba/Faro (Viegas 2011). ${ }^{2}$

\footnotetext{
${ }^{1}$ In this sense, both La Loba and a decontextualised neck from the pottery workshop of Dehesa de Arriba (Posadas, Córdoba) stand out (García Vargas, Almeida, González Cesteros 2011: 195-196; Almeida, García Vargas and González Cesteros 2016).

${ }^{2}$ At Hispalis/Seville, we can document the presence of rims of Dressel 1A and $\mathrm{B}$ from the Guadalquivir in contexts corresponding to the Republican I and II phases of the port complex of Patio de Banderas del Real Alcázar, dated respectively in 100-75 and 50-25 BC (García Vargas, Almeida, González Cesteros 2011: 196-198); the incomplete specimen of
}

In view of the data we currently possess on this class of containers, a date between 100-90 BC can be proposed for the oldest products of the type and for the end of its manufacture sometime within the third quarter of the 1st century BC. By then, they are clearly outnumbered by the Ovoid types of the Guadalquivir in centres of consumption.

\subsection{T-7.4.3.3.}

A third group of amphorae in existence prior to the Ovoid types is also the result of imitation, at least in their beginnings: the T-7.4.3.3. This type, also known as Mañá $\mathrm{C} 2 \mathrm{~b}$, is one of the most widespread late Punic productions of the coastal Ulterior. The primacy of production and export of this particular container - an imitation of the Carthaginian T-7.4.3.1 by way of the T-7.4.3.2 of the south of the Iberian Peninsula (Sáez Romero 2008: 647-648; Sáez Romero et al. 2016) - extend from the beginning of the 1st century BC (Lagóstena Barrios and Bernal Casasola 2004) to the last quarter of this same century from the bay of Cadiz to the coast of Granada. Atypical fragments from Santarém (Portugal) (Arruda and Almeida 1998: 215) have opened the question of the existence of T-7.4.3.3 being produced on the Guadalquivir valley and not on the coast of the Province, as is later shown to be the case by other fragments on the same site and by others in western Hispania (Almeida 2008: 51-59).

With regard to the chronology and distribution of the 'variant' from the Guadalquivir, its production and marketing seems to have been already under way in the first half of the 1st century BC (García Vargas, Almeida and González Cesteros 2011: 200). This is arguably indicated both by a specimen at Cerro do Cavaco (Tavira/Portugal), and more so by another one from Monte Molião (Lagos/ Portugal), with a fabric attributable to the Lower Basin of the Guadalquivir river, found within an area dedicated to domestic metallurgical activities (Arruda and Pereira 2010: 706-707). The rest of the known specimens of T-7.4.3.3 of the Guadalquivir species date to the second half of the 1st century $\mathrm{BC}$ and are also located in sites in what is now Portuguese territory, ${ }^{3}$ to which must be

the unpublished Itálica deposit is dated around the middle of the 1st century BC and is accompanied by Italian Dressel 1, Cadiz T-7.4.3.3.-type amphorae, regional Dressel $1 \mathrm{C}$ and a large group of regional Ovoid types from the Guadalquivir, mainly types 1, 3 and 6 (García Vargas, Almeida and Fabião forthcoming); at Cerro do Cavaco (Tavira, Portugal), maybe the earliest contexts with Dressel 1 from the Ulterior are from the first half of the 1st century BC; at Faro from the last third of the same century (Viegas 2011: 205, 246, Est. 29, nos 419 and 420); at Mesas de Castelinho (Almodôvar, Portugal) some specimens from the first century BC are detected (Fabião and Guerra 1994: 279-280; Fabião 1998, 2001) although they mostly date from contexts already in the Principate, corresponding to horizons of rebuilding campaigns (Parreira 2009: 56; Est. XII and XIII); and at Santarém (Portugal), where the published dates are already within the second half of the 1st century $\mathrm{BC}$, in particular in the last quarter of the 1st century BC (Almeida 2008: 68-69).

${ }^{3}$ Mesas do Castelinho (Parreira 2009: 50), in contexts of the 1st century $\mathrm{BC}$, before to the establishment of the Principate; Faro in contexts of the second half of the 1st century BC (Viegas 2011: 197); Quinta do Almaraz (Almada), from surface, together with other materials with evident late Republican significance (Barros and Henriques 2002 apud Almeida 


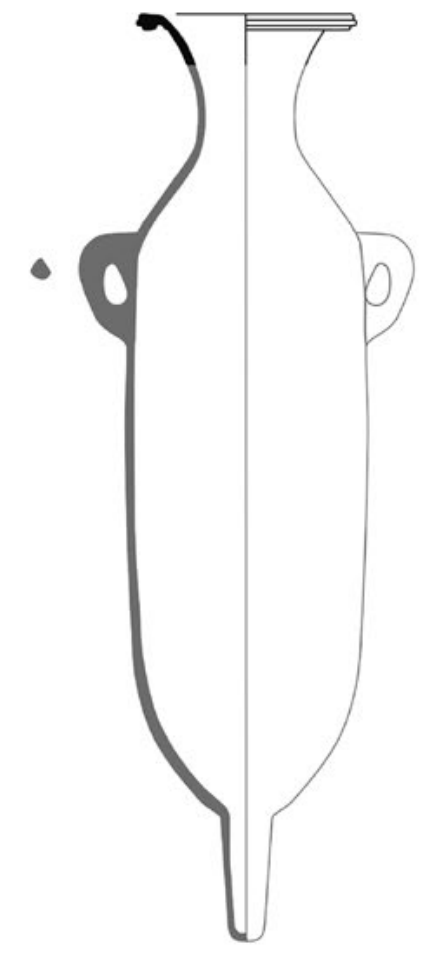

0

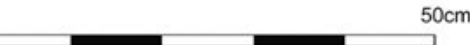

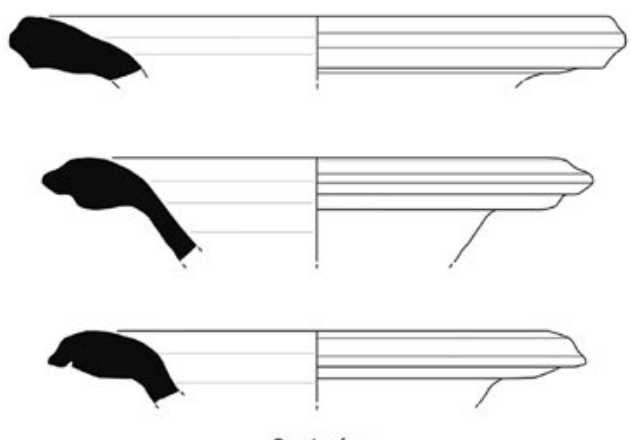

Santarém

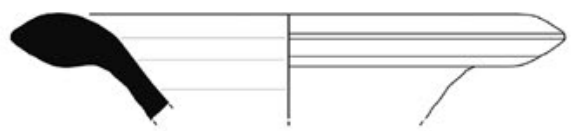

Quinta do Almaraz

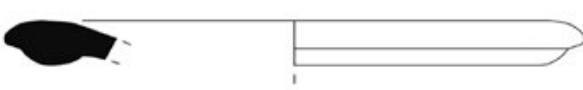

Mesas do Castelinho

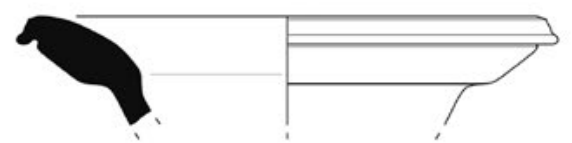

Monte Molião



added a couple of specimens from the Patio de Banderas de Sevilla: one decontextualised and another dated in the third quarter of the 1st century BC (SU 2080) (García Vargas, Almeida and González Cesteros 2011: 200).

Although we do not know the scale of export for that T-7.4.3.3 amphora type manufactured in the Guadalquivir valley, yet the low number recovered (even taking into consideration erroneous identifications of documented specimens) seems to indicate that they made only a very minor contribution to the total volume of the sort throughout the 1st century BC (Almeida 2008: 58-59).

\section{Ovoid amphorae from the Guadalquivir valley}

At an uncertain moment in the first century BC, but which will probably have been towards the beginning of the second third of the century, at the poorly known Republican workshops of the Guadalquivir valley there were devised a group of amphorae types that had in common the ovoid shape of their body, as well as other 'secondary' features. Thereby was established the 'family air' that all of them share between themselves.

Their general morphology and the fact that they appear 'on the market' abruptly, with hardly any formative period

2008: 58-59); Scalllabis (Santarém), in contexts attributable to the final moments of the Republic and the beginning of the Empire (Almeida 2008: 57-59). and without evolving from other existing types, has led to them being considered as more or less immediately successful imitations of other foreign forms, especially ovoid types from Brindisi (cf. Manacorda in this volume). The whole factor of imitation when applied to amphorae is too complex (cf. Bernal Casasola 2014) to be approached here in a fitting manner, especially when involving forms for which an available exogenous prototype can seldom be nominated with certainty. Nonetheless, we believe we are close to the truth in viewing most of these ovoid forms from the Guadalquivir as 'interpretations' rather than 'imitations' of other Mediterranean ovoid morphologies, especially the Italian, but also the African.

In earlier papers, published by us in 2011 and more recently in 2018, we divided the ovoid types of the Guadalquivir valley by their 'commercial success' into two groups that were treated independently. Here we will treat them successively according in numerical order of type, leaving the historicalarchaeological evaluations to the final section.

\subsection{Ovoid 1 (= Class 67, Lomba do Canho 67 or LC67)}

The type included in the Republican repertoire of the Guadalquivir valley under the name of Ovoid 1 is probably the best known and studied one. Within the Roman tradition of the late Republican period, it is perhaps the best example of a creation inspired by existing Mediterranean forms, but with its own personality. 
These amphorae have ovoid bodies, terminating in hollow spikes of a conical tendency; above they have a short neck, small handles of a quarter-circle shape with ridges along their lengths. They are easily recognizable when fragmentary by their typical almond-shaped rim, with a marked moulding or 'collar' below it.

The type was recognised early in the archaeological literature (Lamboglia 1955: figs. 15-16; Callu et al. 1965: 100-101; Domergue 1973; Nolla Brufau 1974-1975: 170, fig. 16.4; Boube 1979-80: 100), but its identification as a specific form and its consequent identification/ characterisation as a type did not take place until the publication by Fabião of the amphorae from the Roman camp of Lomba do Canho (Arganil/Portugal), where he named it as an amphora from the 'Class 67' (Fabião 1989: 65-73). The name derives from the addition of one more class to the open-ended typology established a few years earlier by D. Peacock and D. Williams (1986). The infrequent use of British typology in continental research led to the name 'LC67' or 'Lomba do Canho 67' becoming ever more frequent in the reference archaeological bibliography, and was hallowed by J. Molina Vidal in his study of this type and its presence in late Republican contexts of Eastern Spain (Molina Vidal 1995, 1997).

Given the complete absence of any formal connection between Ovoid 1 and the pre-existing amphorae typology in the Guadalquivir (vide supra), what was then seen as the most likely explanation was that it corresponded to a new creation based on external prototypes for its profile, very likely Italic. However, the lack of an Italic prototype in any way comparable in shape then led also to a possible origin being sought in the Western Punic productions, as initially proposed by C. Fabião (1989: 66). Eventually though, the 'Italian connection', specifically a Brindisian one, was finally chosen by that scholar (Fabião 1989: 67).

Later, in the next century, a study of the amphorae from the Guadalquivir valley was presented for the site of Scallabis/Santarém (Portugal) (Almeida 2008: 70 ss), specifically those of late Republican chronology: this work consolidated the hypothesis of a possible connection between this Hispanic amphora and the southern Italic and/or central Adriatic forms. At the same time the nomenclature Type Ovoid 1 of the Guadalquivir was introduced, based on a systematised classification of a regional character according to the production area/ origin of these Hispanic containers. This recognition made this type the visible and named tip of a much larger corpus, which (like an iceberg) consists of many similar types produced in Ulterior on its southern coastal areas, but not yet fully visible and comprehended (Almeida 2008: 70 ff, 2010: 194-195).

This interpretation has prevailed in the research (Molina Vidal 2001: 641; Fabião 2001: 672; Bernal Casasola and García Vargas 2008: 12; Almeida 2008: 70; García Vargas 2010; García Vargas, Almeida and González Cesteros
2011: 212; González Cesteros, Almeida and García Vargas 2016; González Cesteros, García Vargas and Almeida 2018). Broadly, the immediate origin of the Ovoid 1 of the Guadalquivir is pursued in forms such as Baldacci $1 \mathrm{C}$ from Apulia (Baldacci 1972: 26-27 and Tav. 1.12), and in forms II/III and IV of the Apani workshops (Palazzo 1988: Tav. XXIX; 1989; 2013). Perhaps the most probable to date are the mid Adriatic types of Piceno, with their moulded rims and handles of practically identical form to those of this Hispanic type, dated between the turn of the 2nd century and 30 BC (Carre and Pesavento Mattioli 2003: 459-460 and Tav. I): these are documented for example in the pottery workshop of Cesano de Senigallia (Cipriano and Carre 1989: 77-80) or in the colony of Herdonia (Stefano 2008: 120, Tav. XXIV). Their best manifestation is in the Palombina shipwreck (Mercando 1975-81) (Almeida 2008: 70-72; García Vargas, Almeida and González Cesteros 2011: 212).

With respect to the date of appearance of the type, a chronology at the end of the first third of the 1st century BC is still accepted. Proposed by Fabião, based on the chronology of the Roman camp of Lomba do Canho (Arganil, Portugal) (Fabião 1989: 66-68), and subsequently confirmed by finds first in the praesidium and later the colony of Scallabis/Santarém (Almeida 2008). Further examples come from Monte dos Castelinhos (Vila Franca de Xira, Portugal) (Pimenta, Mendes and Norton 2008; Pimenta and Mendes 2014), Mesas do Castelinho (Almodôvar, Portugal) (Fabião and Guerra 1994; Fabião 1998; Parreira 2009) and Castro Marim (Arruda 1996; Viegas 2011), all of them in the territory of western Ulterior corresponding to modern Portugal. They also turn up in the southeastern markets of Hispania Citerior around $60 \mathrm{BC}$ (Molina Vidal and Mateo Corredor in this volume), as witnessed by several sites studied by J. Molina Vidal (1995, 1997, 2001) and D. Mateo Corredor (2016).

The evidence available in places where the amphorae were consumed points towards a period of maximum export in the third quarter of the 1st century BC. In addition to data from contexts on land, some wrecks help certify this scheme of dating, also documenting their circulation on the major marine commercial routes of the day: GrandConglué 3 (Liou 2001: 1091, Lám. J-K), San Ferreol (Mas García 1985: 205) and Rabat (Boube 1979-1980). Their disappearance from production environments and markets alike seems to occur around the last decades of the 1st century BC (Molina Vidal 2001; García Vargas, Almeida and González Cesteros 2011: 212), or, albeit with less probability, at the beginning of the 1st century $\mathrm{AD}$, as based on several specimens recovered from Scallabis/ Santarém contexts (Almeida 2008: 82). ${ }^{4}$

\footnotetext{
${ }^{4}$ The almost generalised absence of this amphora type in contexts around the $\mathrm{BC} / \mathrm{AD}$ watershed, makes it highly probable that these fragments from Santarém are residual material, incorporated in the strata of the rearrangement and urban remodellings carried out in Augustan and Tiberian times.
} 




Cueva de las Peñas Blancas

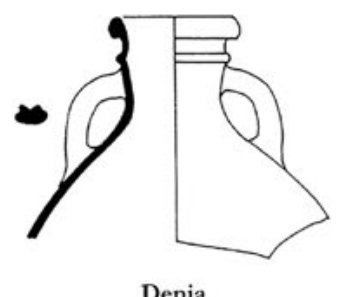

Denia

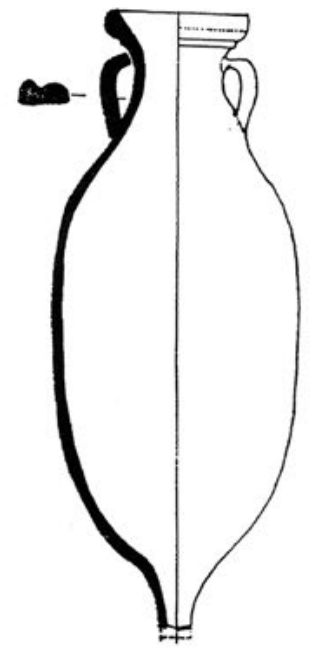

Gran Conglué 3
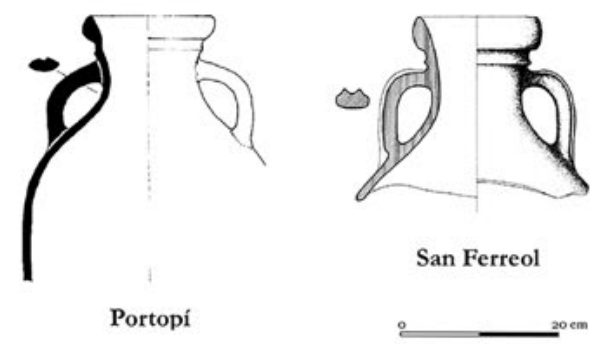


Vila Franca de Xira

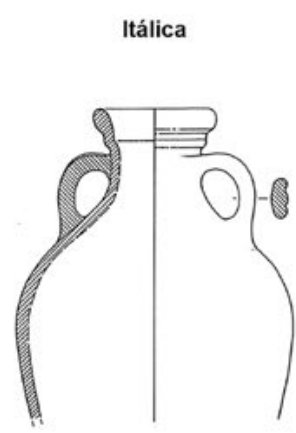

Vila Franca de Xira

Figure 5. OVoid 1. COMPLETE AND SEMI-COMPLETE SPECIMENS.

As for the area of actual production, the situation is contradictory. The production centres of the most widely and numerically exported ovoid amphora from the Republican Ulterior cannot be recognised on the ground in the Guadalquivir valley. To date there exists not a single known pottery workshop in which the production of the type can be categorically affirmed (Almeida 2008: 72), although recent findings have held out some encouraging hints to follow up in the future (cf. point 5.2.1). However, currently the only apparent evidence for known production concerns coastal versions of the same type: from the main pottery-manufacturing areas located on the coast of Ulterior: namely the region of Malaga, the Bay of Algeciras, the Bay of Cadiz and crossing over the Straits of Gibraltar, in the Atlantic-facing Tingitana.

In the first of these regions, on the coast of Malaga, at Cerro del Mar (Vélez), fragments are frequent in its wellknown 'stratigraphic complexes 10 and 11', ranging from the middle of the 1st century $\mathrm{BC}$ to the beginning of the Principate (Arteaga Matute 1985: 216-222); they may be locally produced. Also at Toscanos (Vélez, Malaga), there are several references to suggested production drawn from the existing pottery, none of it though is excavated.

In the Bay of Algeciras, production is witnessed at El Rinconcillo, but only in its Phase III (Fernández Cacho 1995: 183, lam. 4, no. 3-5), which is chronologically poorly understood. Despite recent proposals of a greater antiquity (Bernal Casasola and Jiménez-Camino Álvarez 2004), we are inclined these examples to the central third of the 1st century BC. For its part, Tingitana also documents production, at least in Sala - hence their name of the Sala 1 type, being made towards the middle of the 1st century BC (Boube 1987-88).

As far as the Bay of Cadiz is concerned, the identification of production centres carried out over the last three decades has shown that several of its figlinae - Casa de Huertas (Chiclana), Laguna Salada (Puerto de Santa Maria), Cantera Lavalle and Casines (Puerto Real) produced these amphorae (Lagóstena Barrios 1996; Lagóstena Barrios and Bernal Casasola 2004), although at a low level when compared to the output of T-7.4.3.3, Dressel 1C, 'Gaditan ovoids', and later, Dressel 7-11 (cf. Lagóstena Barrios 1996; Lagóstena Barrios and Bernal Casasola 2004). The recent discovery of a pottery workshop, known as Verinsur (Bernal Casasola et al. in this volume), producing this ovoid type in the Bay of Cadiz is welcome news.

The overview given for the production of the Ovoid 1 type of the Guadalquivir valley and the related forms of the coast (Cádiz and Algeciras bays and the Malaga coast; for the case of Cádiz, cf. Bernal Casasola et al. in this volume) is clearly uneven and disparate. It contrasts sharply with 
the petrographic evidence provided by the fragments known from consumption contexts of the 1st century BC. The majority of specimens (90-95\%) analysed are revealed to be the typical fabrics of the Guadalquivir valley centres, indicating a production set-up with the Middle and Lower Baetis valley as its geographical centre. This pattern is what has emerged from numerous assemblages from settlements of Hispania Citerior (Molina Vidal 2001: 638) - whose inventory has been recently expanded (Mateo Corredor 2016; Mateo Corredor and Molina Vidal in this volume), and again from the western coastal strip of Ulterior itself, mainly in the present Portuguese territory, in sites such as Lomba do Canho (Fabião 1989: 68-71), Santarém/Scallabis (Arruda, Viegas and Bargão 2005: 286; Almeida 2008: 78-82), Mesas do Castelinho (Parreira 2009: 60), Faro (Viegas 2011: 201) and Castro Marim (Arruda 1996; Arruda et al. 2006; Viegas 2011: 487488). Other sites of lesser being but located much more in the interior exist, especially in the Guadiana river valley itself, such as Castelo da Lousa (Morais 2010) and also in Alentejo Central (Mataloto 2008; Mataloto, Williams and Roque 2016; in this volume).

Likewise, when studying/publishing fragments attributable to this type, the diversity of the Hispanic production locales makes it absolutely essential to differentiate them by name and so clearly define their origins. We propose that, according to the place of production, they should be so named differently: we advocate reserving the term 'Ovoid 1' for production in the Guadalquivir valley, and keeping Class 67 or LC67 for products made on the coasts of Malaga, Algeciras, Cadiz or North Africa. Since no specific typologies have yet been developed for these pottery areas (but for the Cadiz Bay, cf. García Vargas and Sáez Romero in this volume) concerning ovoid production in the Roman era, there is no need to apply the terminology generated for another geographical area. Although this is perhaps not the most elegant of solutions, in our opinion it is perhaps the only one that automatically permits one to retain the place of origin in the naming of the pertinent specimens.

As with the other Guadalquivir ovoid containers, the Ovoid 1 type lacks clear evidence of its usual content (if indeed there was only one...). In the first account carried out by C. Fabião, the proposal was advanced that they might be used to transport fish-based contents (Fabião 1989: 6668 ), on the basis, above all, of a supposed existing titulus on a specimen from the wreck of San Ferreol (Mas García 1985: 205). However, it was later established that this was a misperception of the piece and a misinterpretation of the published data. ${ }^{5}$ Subsequently, first by C. Fabião (2001: 673), and then by ourselves (García Vargas 2001; García Vargas, Almeida and González Cesteros 2011: 214216), it was suggested that, as for other pre-Augustan amphora types, the most likely scenario would be

\footnotetext{
${ }^{5}$ This rectification has been communicated to us personally by Prof. Carlos Fabião, to whom we are grateful for this information.
}

that it was a container of a many-sided character, and could have served to carry different articles. This same proposition would allow them to have contents of different sorts, perhaps depending on the different areas of their production: this agrees with what was suggested by other authors (García Vargas 2001; Almeida 2008: 194; Bernal Casasola and García Vargas forthcoming).

This type, then, is manufactured in coastal potteries, and perhaps here the more open and everted profile of their mouths makes them likelier to be a container for fish-products; a deduction arguably reinforced by its production on the Moroccan Atlantic coast. However, for the productions of the Guadalquivir valley (even though salted fish-products made in a fluvial or lacustrine environment is possible), the distance from the coast suggests a different content: oil or wine. To this end also point the obvious similarities in shape of these containers with the Italian, mid and southern Adriatic amphorae, particularly those from Apulia, which all are connected with oil, a product also abundant in the valley of the Guadalquivir. Indeed ever since the first, such a connection was the preferred one. This amphora could thus have been one of the initial vehicles for the export of Baetican olive oil, so famous and widespread in the subsequent centuries (Almeida 2008: 194-195, 287), although wine or defrutum and salted fish cannot be ruled out for the coastal area production. In this respect, it should be remembered that in the Adriatic, the supposed place of origin of the shapes imitated by the Baetican potters, the production of salted fish is also to be noted, although mainly in the more northern latitudes (Pesavento Mattioli and Carre 2009).

\subsection{Ovoid 2}

The form Ovoid 2 was identified from amongst the Republican repertoire at Santarém/Scallabis: it was distinguished from others already recognised - such as Ovoid 1 (=Class 67, LC67) and Ovoid 4 (then called 'Haltern 70 , unusually small variant'), so constituting a new form dated in the second half of the 1st century BC (Almeida 2008: 83-84).

The rim fragments attributable to this type present a simple and solid profile, with a section tending to the subrectangular; they define mouths with diameters between 13.5 and $15.5 \mathrm{~cm}$. With mouths of such a form, should go a neck of reduced length and of bitroncoconical profile, that passes smoothly into the body. Handles of a semi-circular profile and shaped as those mentioned above spring from the neck. In spite of its 'family resemblance' with the other ovoid products of Lower Andalusia, Ovoid 2 cannot be confused with those from the ovoid repertoire of the Guadalquivir valley, such as Ovoid types 4, 5 or 6 (vide infra). Equally, this amphora type also differs from the 'Gaditan Ovoid' one, both in its geographical point of origin and in the morphology of 


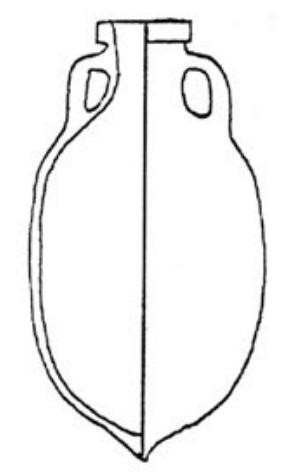

Tipo $1 \mathrm{~A}$ de Baldacci

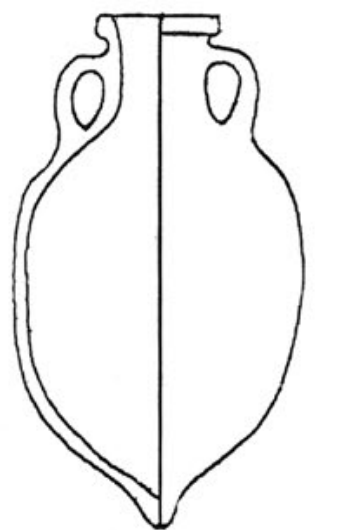

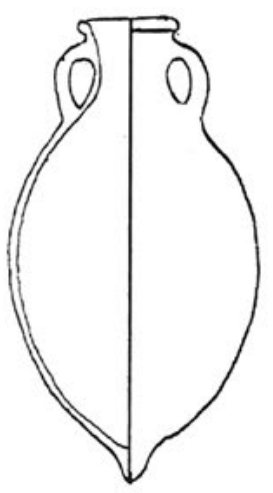

Tipo 1C de Baldacci

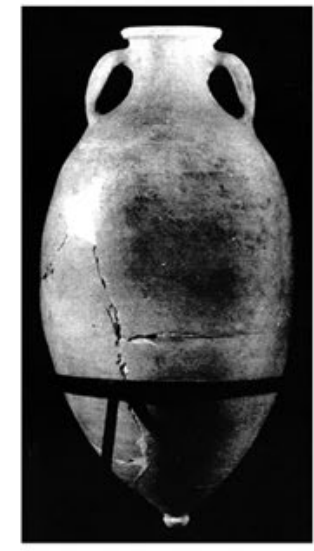

Tipo Va de Apani
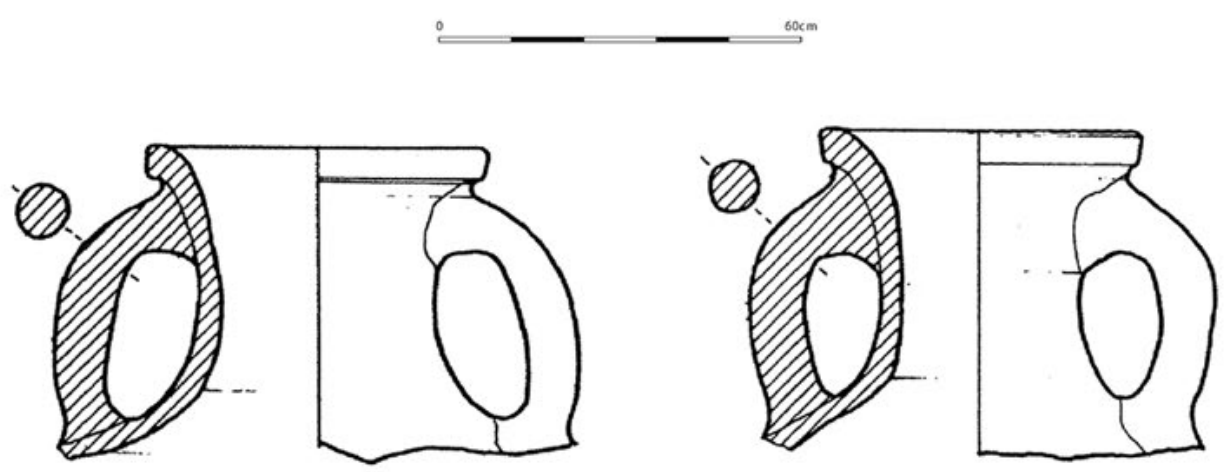

Tipo Va de Apani
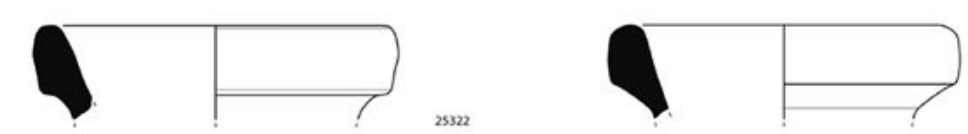

25322

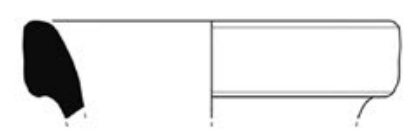

20059

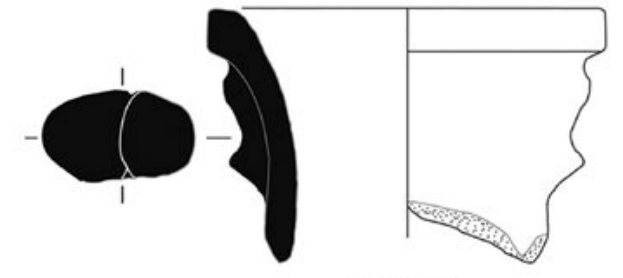

Valeria

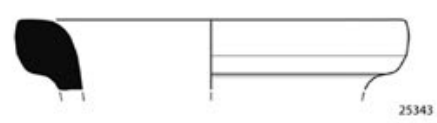

28059

Santarém

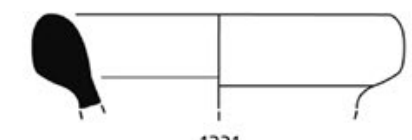

1321

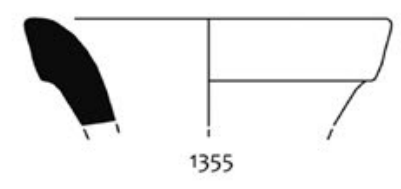

Castro Marim

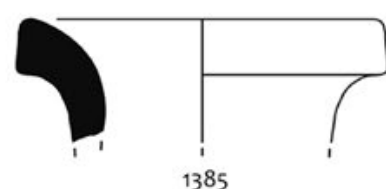

1385
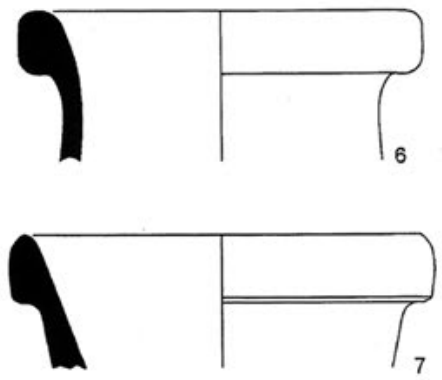

Lixus

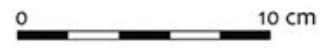

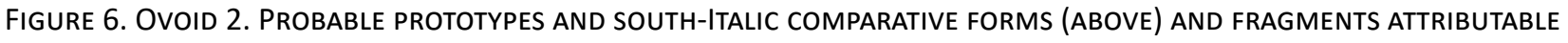
TO THE GUADALQUIVIR TYPE (BELOW). 
the mouth and neck (these being the only elements that can be analysed with any objectivity for the moment).

Until more conclusive data turn up, finally confirming or rejecting the existence of the Ovoid 2 type, we believe that it is preferable and more effective to separate off this type from both the ovoids fashioned in the Guadalquivir region and from those making up within the complex world of the late republican amphora of Ulterior.

The origin of this form, whose separate identity we have tried to justify on two other occasions (García Vargas, Almeida and González Cesteros 2011: 200-202; González Cesteros, García Vargas and Almeida 2018), and which we continue to propose, seems to be also found in the south Italic and mid Adriatic repertoire. Thus, it can be acknowledged that this is an 'inspired' production, that is one typologically close to them. Specific sources could be types 1A and 1C of Baldacci (Baldacci 1972: 25-27 and Tav.1, no. 3, 4 and 10), or Group Va of the productions of Apani (Palazzo 1989: 548-549, fig. 3 no. 17-18, 2013: 19-22), or even Giancola 5 (Manacorda and Pallecchi 2012: 154159), as has already been suggested (cf. Almeida 2008: 8485). Concerning the little-known ovoid products of Lazio, any closeness of form appears minimal, although some sort of 'family' resemblance is possible with some of the examples documented (Hesnard et al. 1989: 24; Benquet in this volume).

Alongside the pieces from Santarém, other, always fragmentary, specimens designated as Ovoid 2 have recently been identified in Castro Marim (Portugal), where they were classified as Haltern 70/Ovoid 4 and Dressel 20A (Viegas 2011: 493-496, Estampa 10, no. 1321, Estampa 106, no. 1355, Estampa 109, no. 1385), and in Lixus (Morocco), in the Middle Mauritanian horizon, also classified as Dressel 20A (Bonet Rosado et al. 2005: 122, fig. 16.6-7). Particularly interesting is a specimen from Valeria (Cuenca, Spain) that presents a handle section that seems to be bifid, although this impression can be erroneously given when representing in a drawing an external groove on the handle back (González Cesteros 2013: 133). One must mention another fragment assignable to the form recovered in the SU 1915 context of the Patio de Banderas of the Alcázar in Seville, dated in the third quarter of the 1st century BC (Ruiz Blanco 2017).

Based on the above, it can be seen that the known fragments of Ovoid 2 are dated around the second half of the 1st century BC. It is clear, especially from the specimens of Seville and Santarém, that the type circulated in the third quarter of the century.

We consider that the characteristics observed and presented are sufficiently different from those present in other types: this then justifies both rescuing them from anonymity and the acceptance of their importance as another diagnostic element and as another reference point when discussing the existence of singular and lesser products whose correct definition continues to escape us at the moment (Almeida 2008: 83-85; García Vargas, Almeida and González Cesteros 2011: 202).

As for its contents, nothing is known. Even so - as has been commented on another occasion (Almeida 2008: 287), perhaps the Ovoid 2 type also transported oil, as it is tempting to equate its form with those of other Italian containers destined for oil exporting.

\subsection{Ovoid 3}

Like the previous type, the Ovoid 3 was also identified and defined from specimens coming from Santarém/Scallabis (Portugal). Again, it represents another case where secure classification is hampered due to the fragmentary evidence and the practical absence of parallels in the established typologies.

The fragments identified in Santarém are characterised in terms of shape by rims whose solid lips of moulded profile are approximately $3 \mathrm{~cm}$ high and tend to a subrectangular section; they define mouths with diameters between 16 and $18 \mathrm{~cm}$. The external and straight (vertical) face of the rim displays an accentuated concavity at its mid-point, so resembling a grooved band, sometimes with a more or less projecting component at the bottom. This projection sometimes gives the appearance of a double moulding on the rim, but in fact it is not so. The rim is clearly distinct from the neck.

Rims with this set of characteristics are usually associated with a short, bitroncoconical neck from which the handles spring: apparently small and with the shape of a quartercircle, they are solid and with a subcircular or oval section. Taking into account all these elements, the amphora form was considered as likely to be another ovoid sort, but one nonetheless distinct from the Ovoid 1 type (Almeida 2008: 86-87; García Vargas, Almeida and González Cesteros 2011: 204-205). Fortunately, in addition to the fragmentary specimens of Santarém on which the definition of the Ovoid 3 type was based, there also exist some complete specimens that serve to establish the standard morphology of these amphorae. For example, there are some of those aboard the wreck Grand-Conglue 3 that were originally classified as 'Dressel 10', because of the rim with its central groove, but the body and pivoted end recall the ovoid products of the Guadalquivir (Liou 2001: 1102, Pl. J, nº 5; cf. Quillon and Luaces in this volume).

Another set of complete Ovoid 3 is represented by two specimens recently recovered in the Italica deposit (García Vargas, Almeida, Fabião forthcoming), which we have already referred to when dealing with Provincial Dressel 1 (vide supra). One of these amphorae is very close in shape to the specimen of Grand Conglué 3 and also has a central groove on the outer face of the rim edge. The second however is slightly different: although the rim edge still sports an external moulding, the small handles 




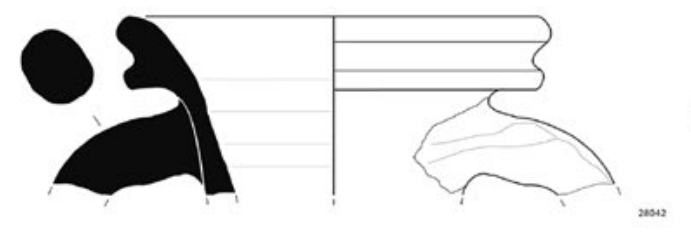

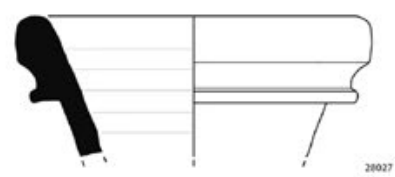

Santarém

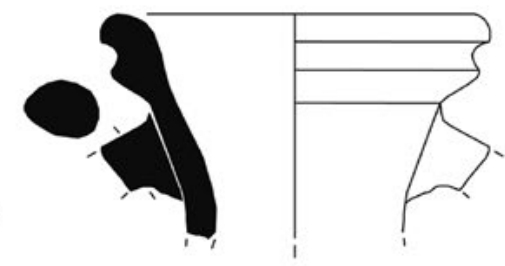

1271

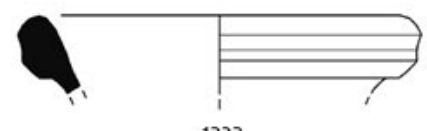

1323

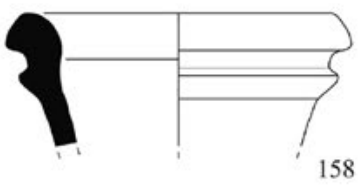

Mesas do Castelinho

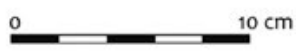

Castro Marim

Figure 7. OVoid 3. Complete SPECIMEN (ABOVE) ANd fRAgments ATtRibutable to the tYpe (Below).

have a subcircular section and the body a pronounced ovoid shape, with its maximum width in the upper half: all features that, in our opinion, assign it to the Ovoid 3 type.

The other fragmentary specimens that we identify as Ovoid 3 come from Castro Marim (Viegas 2011: 486-489) and Mesas do Castelinho (Parreira 2009: Est. XVI.158), again in the territory of modern Portugal. In both cases, the fragments were initially classified as Ovoid 1, but in a recent review they should were reassigned to type Ovoid 3 (García Vargas, Almeida and González Cesteros 2011: 204).

The chronology of the specimens known from consumption contexts lies within the third quarter of the 1st century BC (Almeida 2008: 87; García Vargas, Almeida and González Cesteros 2011: 205), which agrees with that formulated from the specimens of Santarém, Castro Marim and, probably, also those of Italica, given their association with Ovoide 6 and Dressel 1 (García Vargas,
Almeida and Fabião forthcoming). Their presence in the wreck of Grand-Conglué 3 (Liou 2001; cf. Quillon and Luaces in this volume) confirms that the entrance of the Ovoid 3 type into the market had already happened by the middle of the 1st century BC in the Italian or southern Gaulish territories, where indeed the occurrence of other ovoid types of the Guadalquivir is also known (even in the same wreck), a clear sign of its real widespreading to the Roman West.

\subsection{Ovoid 4}

Research carried out in the last decade (Fabião 2001; Almeida 2008; García Vargas 2010; García Vargas, Almeida and González Cesteros 2011, 2016a; González Cesteros, García Vargas and Almeida 2018) has made it possible to clearly identify the late Republican form Ovoid 4 of the Guadalquivir. Previously this was often viewed as an apparently small Haltern 70 (Class 15/ 'Haltern 70 unusually small variant'; Peacock and Williams 1986: 115- 
116). In our opinion, the perception of it as a Haltern 70 small variant is not only erroneous from the formal point of view, but also from the perspective of its cultural, geopolitical and chronological attributes.

This is a container whose full height is close to $70 \mathrm{~cm}$; it has a short, straight collared rim, with mostly a subrectangular profile under $4 \mathrm{~cm}$ tall, a short neck and short handles; it shows an ovoid body with a small and solid conical bottom. In short, its characteristics are far removed from the 'classic' Haltern 70 proper, which circulates from the Augustan era, as proposed in recent works (Almeida 2008: 100-108; García Vargas, Almeida and González Cesteros 2011: 223-224; 2016a).

The morphology of the Ovoid 4 type does resemble the supposed ovoid types from Lazio, specifically from the workshop of Astura (Hesnard et al. 1989: 24-25, fig. 6), ${ }^{6}$ but even so it finds much clearer parallels with material from the southern coast of the Adriatic (Cipriano and Carre 1989: fig. 5; Toniolo 1991: 18, fig. 7, 1996, 2000: 183) in particular in the area of Brindisi, namely with the form VII of Apani (Palazzo 1989: 548-549, fig.4, no. 23-24, 2013: 23-24). The similarities in shape with the Haltern 70 type are indeed evident, which has often led to the confusion between the both types, with the first being considered a smaller module of the latter. To repeat, this is not so, since the two forms only coexisted in the 'markets' for barely a decade (30-20 BC). Further, it is precisely during this period that we see the appearance of the Haltern 70 type, in its first expression termed that of the 'Agrippa fleet' (vide infra), the ovoid type of the preceding decades (García Vargas, Almeida and González Cesteros 2011: 219-220).

Once again, it was C. Fabião (1989) who was the first to propose the morphological disparity between the two types and to point out the relevant chronological one too, supported by the evidence of specimens found at the late Republican military camp of Lomba do Canho (Arganil/Portugal). Accordingly, he proposed that the 'real Haltern 70' should be maintained within Class 15 of Peacock and Williams (1986: 115-116), while the 'small variant' of the late Republican times should be assigned the classification of Class 15A (Fabião 1989: 6164). At the same time, he also confirmed the existence of another Republican form, with which he considered that the Class 24 designation of Peacock and Williams should be placed. Nonetheless, in the following years and papers the differentiation between Classes 15 and 24 was not, however, completely clear (cf. Fabião 2001). Later on, when the reordering of the Republican types of the Guadalquivir valley was carried out because of the material found at Scallabis/Santarém (Portugal), the first of Fabião's suggested types (Class 15A) became the type Ovoid 4, and the second (Class 24) the type Ovoid 6 in the Guadalquivir valley ovoid repertoire: a proposal of Almeida (2008).

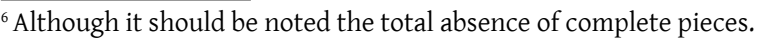

Although the morphological proximity between Ovoid 4 and the 'initial' Haltern 70 makes it difficult to distinguish between them when there are only fragments (Fabião 1989: 63; Almeida 2008: 102-108), it can be pointed out that, as a general rule, the rims of Ovoid 4 are shorter than those of Haltern 70, although this is not an absolute criterion, and must be judged with respect to other parameters such as the thickness of the piece and the general morphology of the profile of the rim, which is usually in the form of a marked 'collar'. Likewise, the dimensions of other parts of the amphora - neck, handles, body and pivot - are also much smaller in the Ovoid 4 type (Almeida 2008: 102; García Vargas, Almeida and González Cesteros 2011:218).

With regard to complete specimens, a barrier to ready identification lies in their resemblance to other contemporary coastal products, which has led to several Ovoid 4 in some wrecks published early on, such as Titan or Grand-Conglué 3, being systematically confused with 'Gaditan Ovoid' type and/or Dressel 10, both sorts of a very different origin (Liou 2001; cf. Quillon and Luaces in this volume).

In the wreck of Madrague de Giens, dated around 70-60 $\mathrm{BC}$, what is now seen as a possible Ovoid 4 was discovered, but was then classified as a Haltern 70 (Tchernia 1990: 296). This happenstance led to the widespread acceptance that the Haltern 70 type, so typical of the Augustan era and of the 1st century $\mathrm{AD}$, began to be produced in the first decades of the 1st century BC. In our opinion, it is an Ovoid $4,{ }^{7}$ which would argue for at least the second quarter of the 1st century BC for the initial appearance of this type and also remove the need to place the beginning of the Haltern 70 at such an early moment. ${ }^{8}$ Apart from the controversial specimen of the Madrague de Giens, we can cite the presence of amphorae of the Ovoid 4 type among the specimens found in wrecks such as those of Grand-Conglué 3 (Liou 2001), Titan (Benoit 1956), Portopí (Cerdá Juan 2000), Cap Gros 'C' (Gauthier and Joncheray 1993), Cala Bona I o Illes Formigues I (Martín Menendez 2008), whence comes the specimen of the Maritime Museum of Barcelona published by Peacock and Williams in 1986 (Martín Menéndez 2008). The same pattern is met with in the complete, or mostly fragmentary, specimens from terrestrial contexts, such as those at the so-called Cybele sanctuary in Lyon (Lemaître, Desbat and Maza 1998), the D cardo of Ampurias (Aquilué Abadías et al. 2004: 113, fig. 68), the Peñas Blancas cave in Cartagena (Lillo Carpio 1986:125), at Tarragona (Gebellí i Borrás and Díaz García 2001; Díaz García and Otiña Hermoso 2003), in the Las Concepcionistas convent in Vejer (García Vargas 2001: 66), Corts Valencianes in Valencia (Pascual Berlanga and Ribera i Lacomba 2001), the Roman camp of Lomba

${ }^{7}$ Currently this cannot be confirmed by inspection, as the item has not be found.

${ }^{8}$ The bottom line is that at the moment, the known contexts and evidence do not reveal any specimens in the second third of the 1 st century $\mathrm{BC}$ that can be considered a 'typical' Haltern 70 (Almeida 2008: 100). 


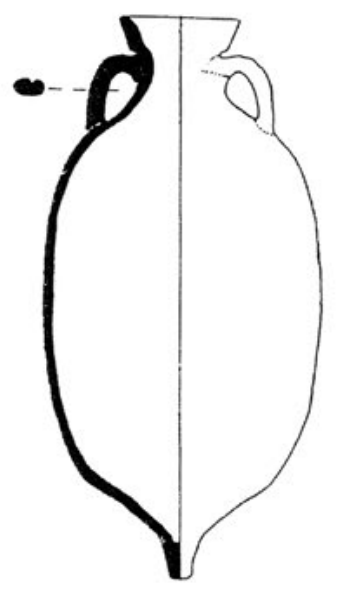

Grand-Conglué 3
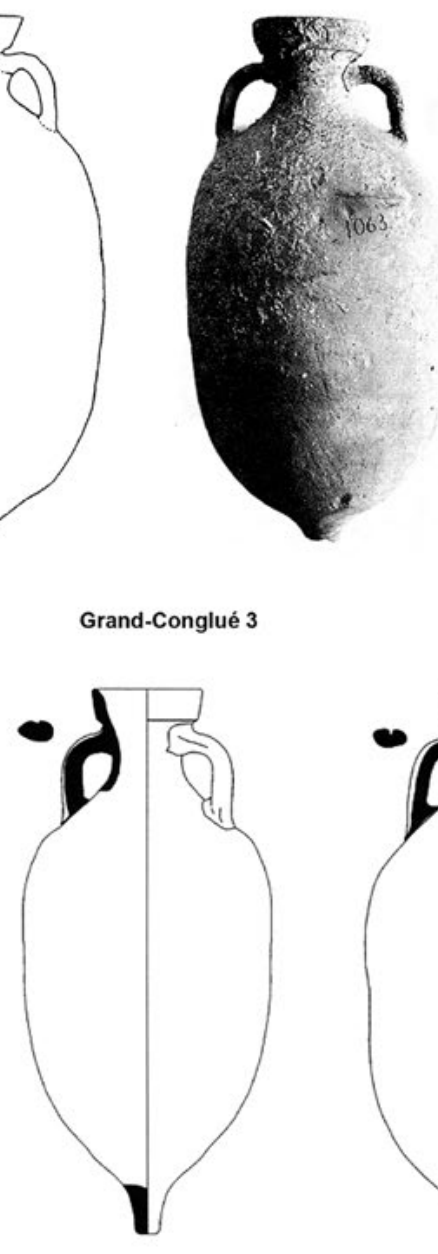

Cala Bona I

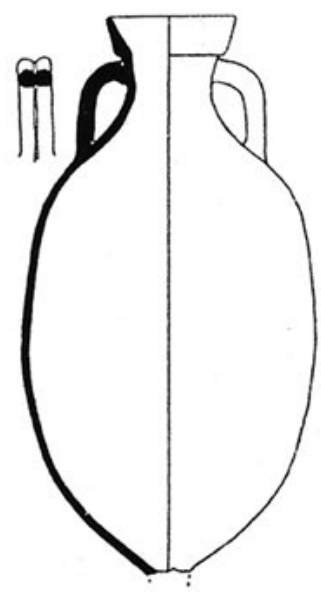

Titan

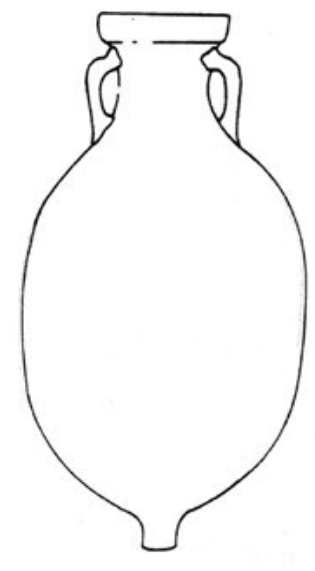

Lomba do Canho
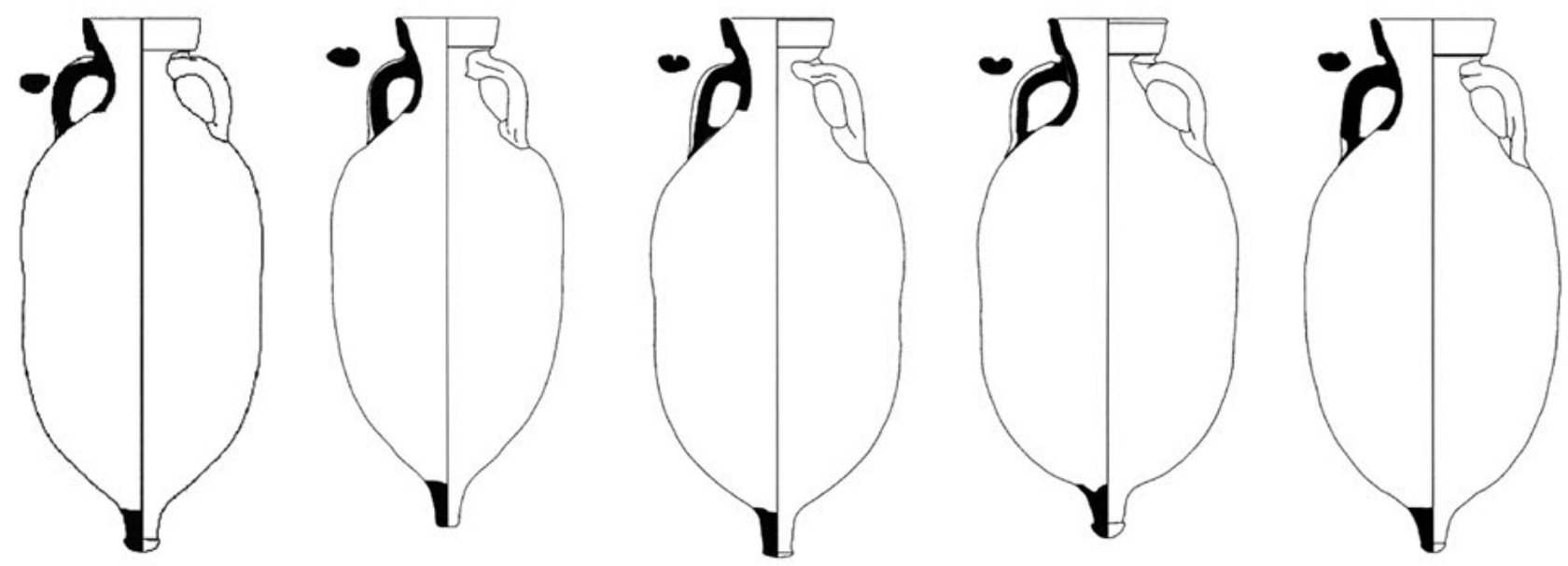

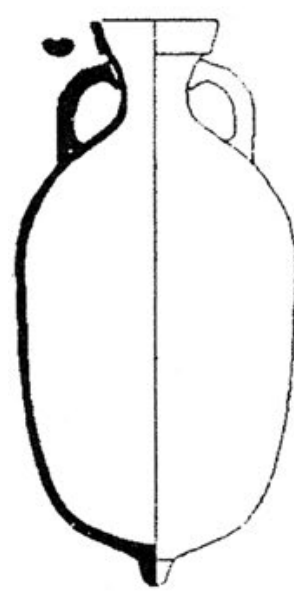

Corts Valencianes

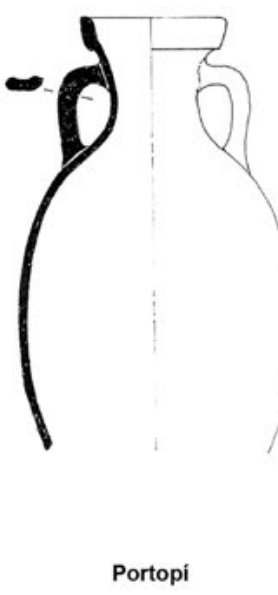

Portopi

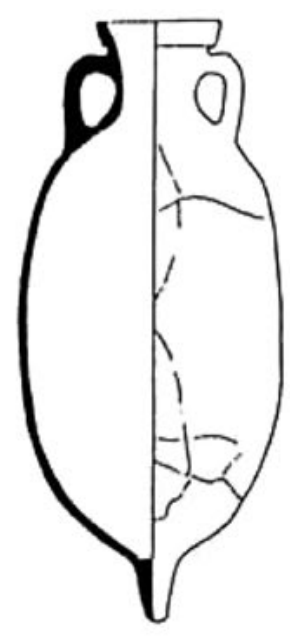

Santa Trega

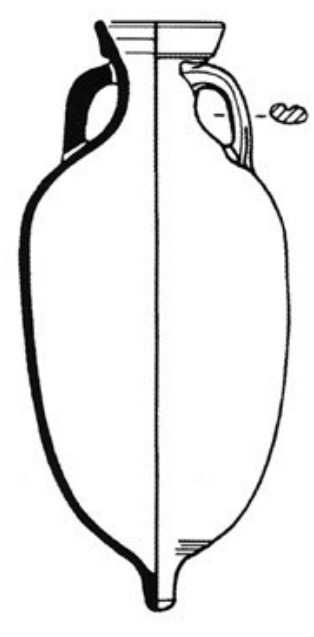

(1)

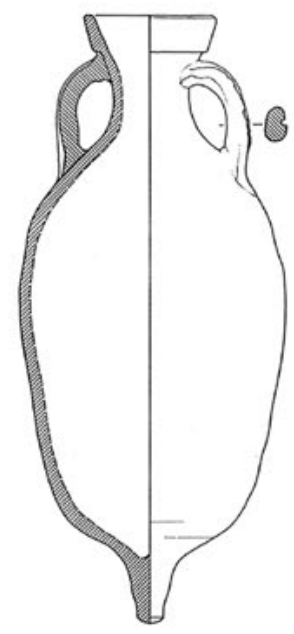

Vila Franca de Xira

FIgURE 8. OVOID 4. COMPLETE AMPHORAE OF THE TYPE. 

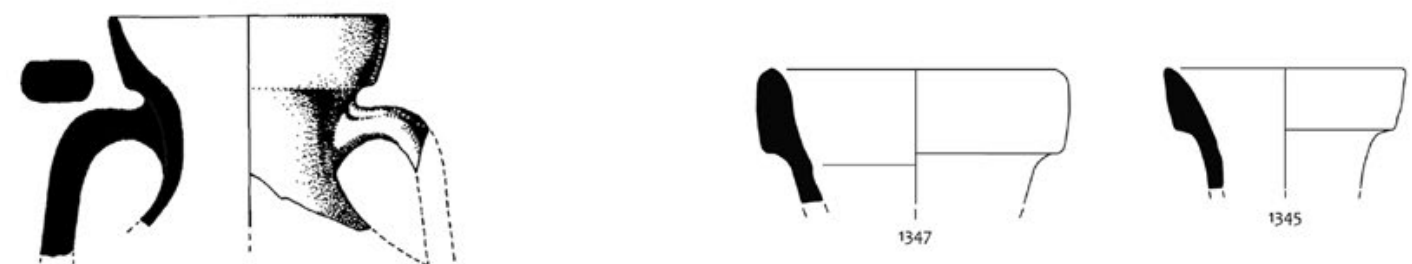

Cueva de las Peñas Blancas
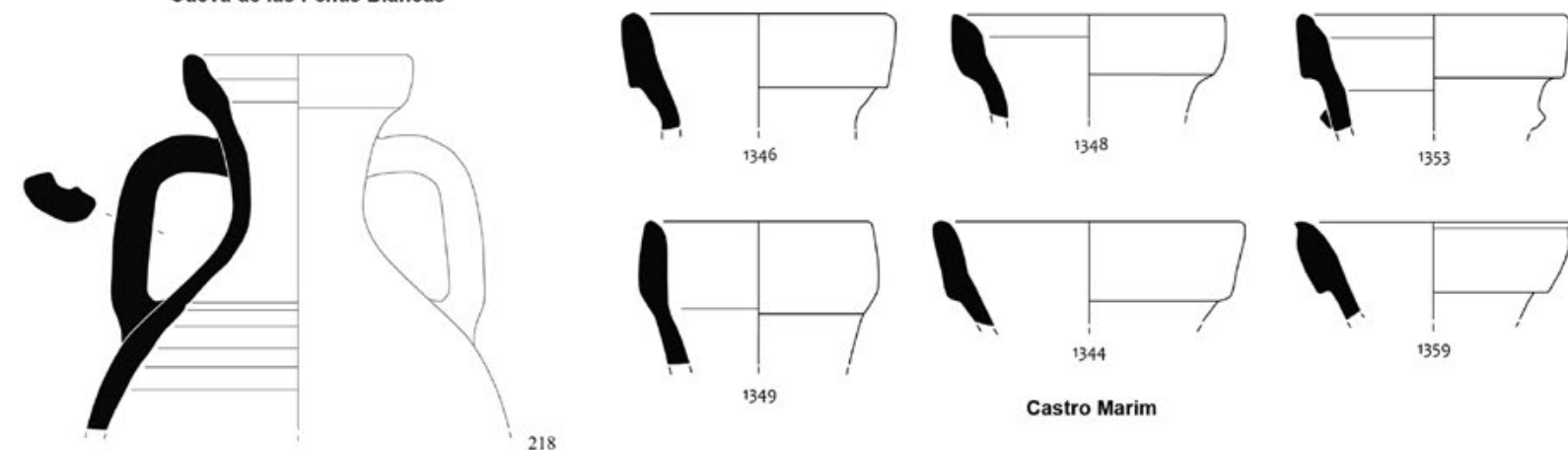

1344

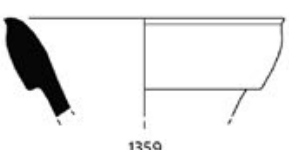

1359

218
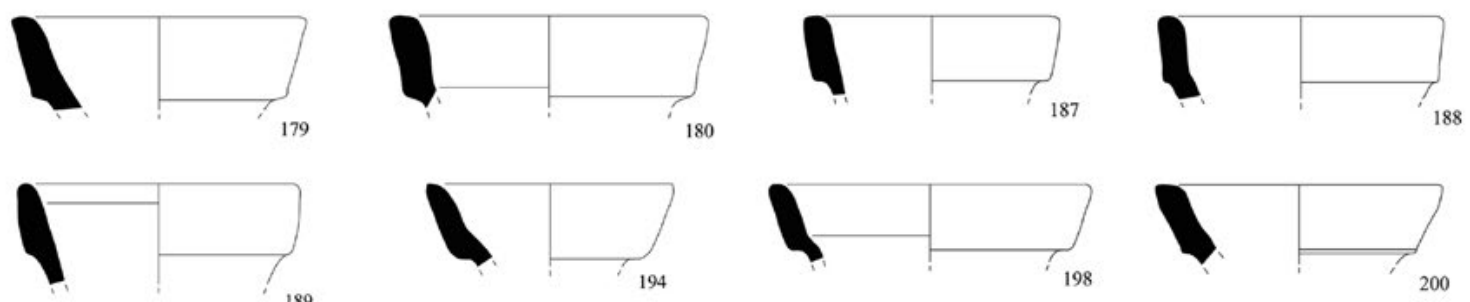

Mesas do Castelinho
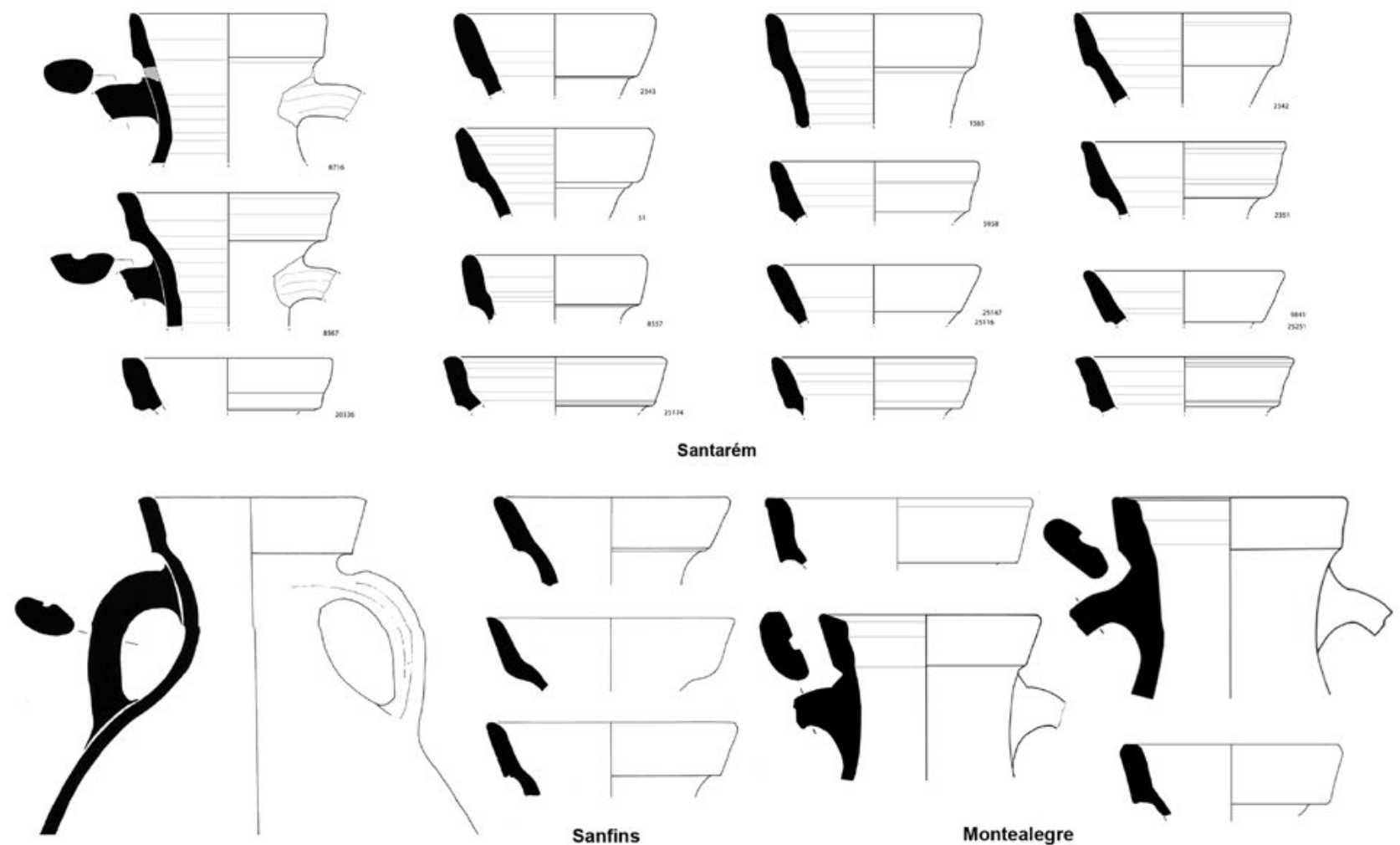

Montealegre

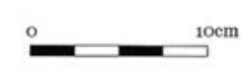

Figure 9. OVOId 4. FRAgMENTARY EXAMPLES OF AMPHORAE OF THE TYPE. 


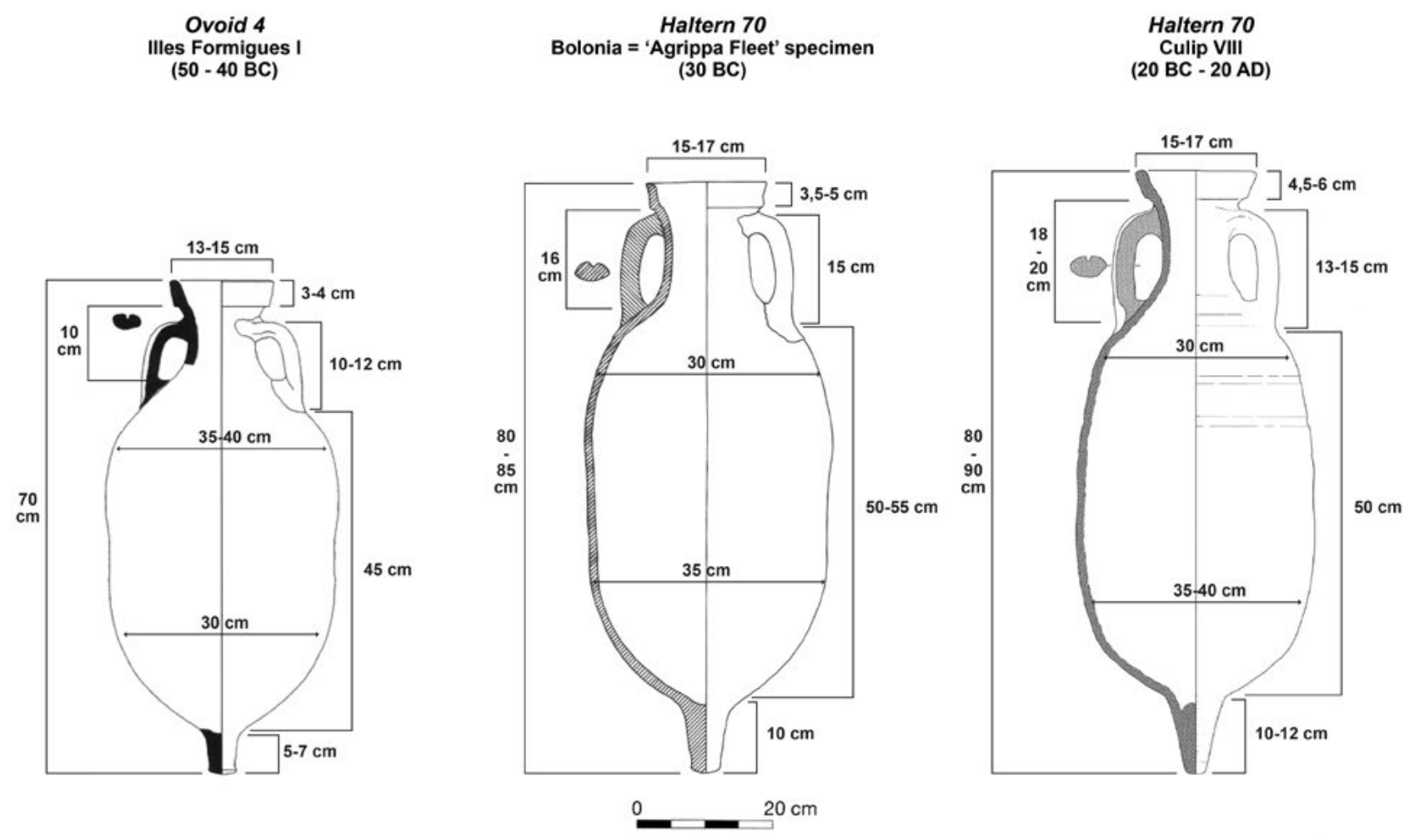

Figure 10. OUtLINE OF the EVOLUTION FROM OVOID 4 to HALTERN 70.

do Canho (Arganil, Portugal) (Fabião 1989), Scallabis/ Santarém (Portugal) (Almeida 2008), Mesas do Castelinho (Almodôvar, Portugal) (Parreira 2009) and Castro Marim (Portugal) (Viegas 2011) (cf. Almeida 2008: 100-101; García Vargas, Almeida and González Cesteros 2011: 219-223).

The end of the Ovoid 4 type coincides and partially overlaps with the start of the Haltern 70 (García Vargas, Almeida and González Cesteros 2011: 233-234). The terminal stage of Ovoid 4 runs between 30 and $20 \mathrm{BC}$, which should surely have coincided with the first attempts at producing the Haltern 70, whose physical features then are still poorly defined as a result of a certain initial 'experimentation'. In fact, the sorts of Ovoid 4 visible in the contexts of the years 30-10 BC at Corts Valencianes do present a certain resemblance with the 'initial' version of Haltern 70 (Pascual Berlanga and Ribera i Lacomba 2001: 576; Ribera i Lacomba 2010). We believe just one decade, 30-20 BC, was required for the Haltern 70 to emerge commercially as a differentiated type. This sequence places the Ovoid 4 as prior to the Haltern 70 proper, whose evolution is from those intermediate forms that we call 'initial Haltern 70'. Further the Haltern 70 replaces the Ovoid 4 in the AtlanticMediterranean markets during the last two decades of the 1st century BC: this then is the moment when the Ovoid 4 of the Guadalquivir definitely disappears (García Vargas, Almeida and González Cesteros 2011: 223-224).

One may summarise our proposal for the 'Ovoid 4-Haltern 70 ' story thus:
1. Ovoid 4- beginning around $70 \mathrm{BC}$ and disappearing around $20 \mathrm{BC}$.

2. Haltern 70 'initial' version - documented around $30 \mathrm{BC}$, coexisting with Ovoid 4. These include specimens such as were located in the "Field of the Fleet of Agrippa' or on the coast of Baelo Claudia (of underwater origin): they are characterised by a broad neck and, in general, more massive proportions than the later 70 Haltern proper.

3. Haltern 70 amphorae - fully developed (or 'classical') - is found from c. 20 BC (cf. García Vargas, Almeida and González Cesteros 2011: 224 and fig.19).

The morphology of the container does not seem to be the only point of affinity between the two types: the same can also apply to their content(s). This at least is what can be deduced from the specimens of the wreck of Illes Formigues 1: all of them contain resin on the inside (Martín Menéndez 2008: 106-107), which is not appropriate for an oil container. As such, and based on this recent evidence (which is also the only evidence) for Ovoid 4, it is possible to argue that wine or some other wine-derived product made up the content (cf. Bernal Casasola, Pecci and Sáez Romero in this volume). However, as only one closed group is available, then it remains perfectly possible that it was a container suited to a range of uses. Intriguingly, something similar happens with the Haltern 70 . Though the matter is still contested, the inscriptions in ink and the paleo-remains found reveal it to have been used mostly for the transport 
of products derived from the vine, such as defrutum, and to a lesser extent sapa (Aguilera Martín 2004a; Aguilera Martín 2004b; cf. also Bernal Casasola, Pecci and Sáez Romero in this volume), but also olives are preserved too in these very same sort of amphorae.

In terms of distribution, three main axes can be observed: they are geographically, politically and economically to be differentiated. The initial market-presence, what we can define as immediate, is that contingent on the place of origin (and is obviously the earliest too): we can find several contexts with Ovoid 4 types in both modern-day Seville and Carmona (García Vargas 2010, 2012), as well as in settlements mainly dedicated to extractive activities (mining) or ceramic production, located mainly in the provinces of Cordoba and Cadiz; these date from the mid and second half of the first century BC. Such is the case of the mines of Ermita de San Sebastián, El Piconcillo and Calamón (Domergue 1987), all in the province of Córdoba, or for example of the pottery workshops at Calle Troilo (Niveau de Villedary y Mariñas and Blanco Jiménez 2007: 216, fig. 10.1-2) and Rabatún, and again in Jerez de la Frontera (García Vargas and López Rosendo 2008: 295, fig. 10.4).

A second sphere of commerce is the western Iberian Peninsula, particularly those locales related to the process of the later conquest (Almeida 2008: 100-103, 2010; García Vargas, Almeida and González Cesteros 2011: 224). Here the amphorae can be documented almost systematically as present in all the sites with a clear military connotation, or those that are militarised (that is to say, where the military have been installed in some way or other). These are attributable to the second half of the 1st century BC. Representing a wider range, they do include military sites proper, as at Santarém or Lomba do Canho, but also they appear in or near pre-Roman oppida where a presence of troops is detected, such as at Mesas do Castelinho or Castro Marim, and several of the 'castros' of northern Portugal and present-day Galicia. Finally, with the 'militarised' settlements, the Ovoid 4 type is always present in castella or similar establishments, whether in the Guadiana basin (for example at Castelo da Lousa (Morais 2010)), in the area surrounding Ebora/ Évora (Portugal), in the hillforts of the current Alentejo Central (Mataloto 2008), or even in the southwestern metalla located in the Odiel river basin (Peréz Macias and Delgado Domínguez 2007: 153). ${ }^{9}$

The third zone embraces the eastern half of the Iberian Peninsula. In this large area, the presence of Ovoid 4 is verified in sites of identical nature as the second sphere mentioned above, namely in military or 'militarised' sites such as Pozo Sevilla (Morin de Pablos et al. 2010) or Cabezuela de Barranda (Brotons Yagüe and Murcia Muñoz 2014: 115, Fig. 10.9). In the north-east of Spain, it is recorded in urban areas such as Tarragona (Ruiz de

${ }_{9}^{9} \mathrm{Cf}$. especially fig. 6.1,3, 4 and 6, classified as Haltern 70, although we believe they are Ovoid 4.
Arbulo et al. 2010; Gebellí i Borras and Díaz García 2001; Díaz García and Otiña Hermoso 2003) or in some rural areas such as El Vilarenc (Revilla Calvo 2010). But its presence is especially significant in urban nuclei of the south-eastern Iberian Peninsula, where it was already confirmed by J. Molina Vidal (1997). An updated catalogue of findspots on land and sea that claim imports of Ovoid 4 on the eastern coast of the Iberian Peninsula has been produced by D. Mateo Corredor and J. Molina Vidal (in this volume), to whose work we refer for the specific locations (cf. also Mateo Corredor 2016). It is interesting here to underline the fact, pointed out by these authors, that the majority of the specimens identified in this geographical area date back to the central third of the 1 st century $\mathrm{BC}$ and also to their greater frequency in the southern half of the territory analysed.

Finally, the wrecks (without assigning them to an area, they are to be understood as points en route to the previous identified zones, particularly the third one) such as those of Illes Formigues 1, Cala Bona 1, Titán or Grand-Conglué 3 - unquestionably certify the circulation of these containers towards markets further afield than the Hispanic Peninsula. Southern Gaul with its riverbased routes penetrating far inland forms an emerging civil market as early as the third quarter of the 1st century BC (García Vargas, Almeida and González Cesteros 2011: 224 and fig.19; cf. also Quillon and Luaces in this volume; González Cesteros in this volume).

\subsection{Ovoid 5}

The Ovoid 5 is a type first proposed by one of us (Almeida 2008: 126-134, 2010) and is included in the repertoire of the late Republican ovoid amphorae of the Guadalquivir (García Vargas, Almeida and González Cesteros 2011, 2016b; González Cesteros, García Vargas and Almeida 2018). Unfortunately, once again, this form has suffered from a typological 'invisibility' similar to that afflicting Ovoid 4. As a result, it is customary to classify them with others, with which, however, they should in no ways be confused. In this case, Ovoid 5 is usually muddled with the form Ovoid 1/LC67 due to a small feature common to both, but which however is not even unique to them. This is the medial neck-ring or moulding that they present. Other features of Ovoid 5, such as the shape of the handles, the neck and the insertion of the neck into the shoulders or the body, are quite peculiar to it. They define a container of such a pronounced 'individuality' that it must be typologically considered a type independent from Ovoid 1/LC67.

Despite the lack of standardisation characteristic for ovoid specimens, the rims and upper parts of Ovoid 5 are always clearly distinguishable from the corresponding of Ovoid 1 (=LC 67). Thus, while the rims of the latter are rounded or almond-shaped in section for the vast majority of cases, those of Ovoid 5 amphorae are subtriangular or, less frequently, subrectangular, commonly straight-sided and 

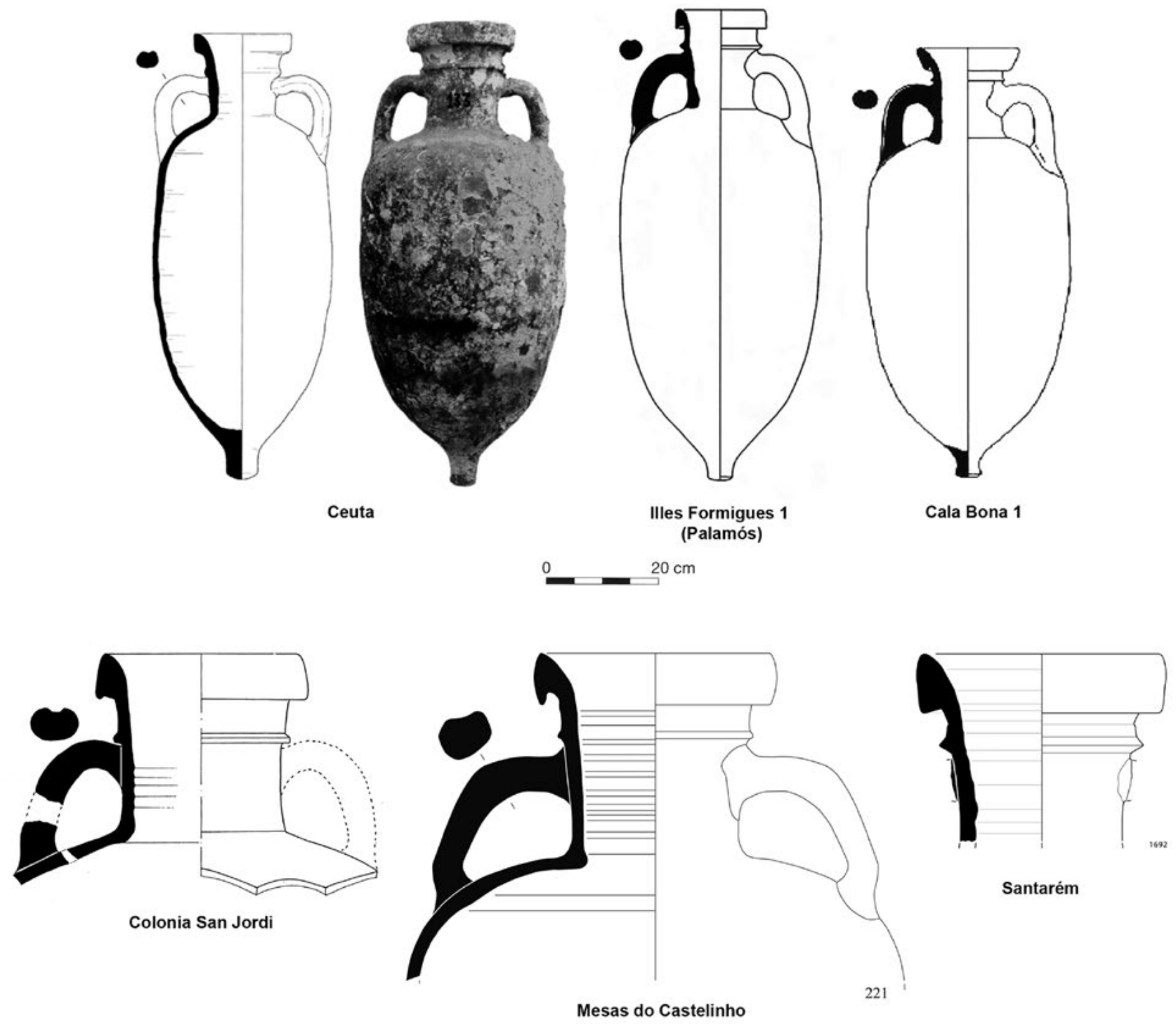

Colonia San Jordi

$10 \mathrm{~cm}$

Figure 11. OVOID 5. COMPLETE AMPHORAE OF THE TYPE.

with a lip pendant towards the exterior (Almeida 2008: 126). Further, the ring component on the neck is also much more marked and distinctly separated; for the Ovoid 1 , the ring is located in the lower part of the rim, whilst in the Ovoid 5, it is set much lower, halfway up its neck. The necks of Ovoid 5 have a marked cylindrical quality, which is why at its juncture with the shoulders there is a strong change in the profile, as if the necks had been inserted into the body 'under pressure', a characteristic that is seen otherwise only for the proposed type Ovoid 9 and in some specimens of the early variants of Haltern $70 .^{10}$ The handles almost always have a sub-circular section, with a little, if deep dorsal groove (a feature practically exclusive to Ovoid 5) and a marked depression at the root caused by the pressure of the potter's finger in a clear attempt to ensure its adhesion to the body. The handles are very short and vertical, due to the stubby neck, the

${ }^{10}$ Those that we have defined as 'Haltern 70 type Fleet of Agrippa' (García Vargas, Almeida and González Cesteros 2011: 243-244). width of the shoulders and the profile created by their joining.

The complete examples from the wrecks of Illes Formigues I and Cala Bona I (Martín Menéndez 2008) and again Ceuta (Bernal Casasola 2007; cf. García Vargas, Almeida and González Cesteros 2011: 227, fig. 20; González Cesteros, Almeida and García Vargas 2016b) show an ovoid body with a pointed profile, wide shoulders and finishing in a small solid pivot, a morphology that is generally reminiscent of that of the Dressel 25 and, above all, of the amphorae of type IV of Apani and 4 of Giancola (Palazzo 1988: tav. XXIX.3, 2012: 29-30; Manacorda and Pallecchi 2012: 152-154; Manacorda in this volume), or type 2 of the wreck Cap Gros C (Gauthier and Joncheray 1993: 178), assuming that this last specimen is a Brindisian production.

The Ovoid 5 can no longer be confused, even in the case of small rim fragments, with Republican amphorae similar 
to Dressel 12, which also have a ring at the base of the rim. In fact, as in the Ovoid 1 type, this moulding or rim is set a little higher in these amphorae related to the early Dressel 12, such as those recovered at Cap Béar $3 .{ }^{11}$ On the other hand, the rim edges of the latter are rounded or oval, very far from the solidity of appearance given by those of the Ovoid 5. The vast majority of the Dressel 12 have fabrics typical of the Baetican coastal area, while the Ovoid 5 has clays at home in the Guadalquivir valley, although it is not the characteristic 'brown' fabric present with Ovoids 1 or 4 and so identical to that of the Dressel 20 , but a more porous and whitish clay that is commonly used in the manufacturing of common wares and of other amphora types such as Urcei and Dressel 28.

As for other production areas within Hispania Ulterior, it cannot be ruled out a priori that a series of amphorae formally similar to the Ovoid 5 were being made on the Mediterranean littoral of Ulterior. For example, in the contexts of Cerro del Mar (Velez, Malaga), both those published by O. Arteaga (1985) and those from the German Archaeological Institute's campaign in 1998 (and directed by 0 . Arteaga himself) that still remain unpublished, fragments morphologically classifiable as Ovoid 5 type are associated with Dressel 1C, LC67 and T-7.4.3.3., as well as with Campanian B black-gloss ware (forms Lamboglia 1 and 2). The lack of a description of the fabrics makes it difficult to know whether they are local productions from the area of Velez-Malaga or imports from the Guadalquivir valley.

The poor archaeological 'visibility' of the Ovoid 5 gives it, as with the Ovoid 4, the appearance of being a 'minority container', which is actually deceptive. However, wherever Ovoid 1 and Ovoid 5 can be safely told apart, it is clear that the number of (complete or fragmentary) specimens is far from being at a 'minority' level within the parameters that portray the amphorae of Late Republican Hispania Ulterior (García Vargas, Almeida and González Cesteros 2011: 225-226; González Cesteros, Almeida and García Vargas 2016b). From the recent excavations at Patio de Banderas of the Alcazar of Seville have come a series of fragmentary specimens (cf. García Vargas, Almeida and González Cesteros 2011: fig. 21) found in contexts related to the construction of the opus africanum architectural complex (Tabales Rodríguez 2015), a series of buildings whose opening chronology has been established between 50 and 25 BC. This date seems to be at the moment of maximum dissemination for the

\footnotetext{
${ }^{11}$ In this shipwreck, dated in the third quarter of the 1st century $\mathrm{BC}$ (Liou and Pomey 1985: 547-550, figs. 2-3; Liou 1987: 273 and fig. 3), several amphorae of this type were collected, some of them with the typical moulding highlighted on the upper part of the neck, which in turn was long and straight. Also in other shipwrecks are recorded specimens with similar characteristics, although the rims are less vertical, more everted and with a slightly ellipsoidal profile: Titan (Benoit 1956: 29 and fig.11, nos. 11-13; Tailliez 1961), with a date centreed on 50-45 BC (Tchernia 1990: 300); that of Grand Conglué 3 (Tchernia 1969: 483-485; Liou 2001: 1071 and 1102, Pl.-J), also dated from mid first century BC; and that of Fos, of an identical chronology (Giacobbi and Lequément 1987: 183 and fig. 11, no. 4).
}

type in the area of the Lower Guadalquivir, where the producing workshops must have been located and where its survival into the Augustan period is not yet confirmed (cf.García Vargas, Almeida and González Cesteros 2011: 225-228). In the specific case of the Patio de Banderas in Seville, here they are even more abundant than Ovoid 1 and Ovoid 4, which, although it may be a fortuitous occurrence, can also be considered proof that these are not minor players in the market.

Exemplars virtually identical to those of Patio de Banderas in Seville are documented at Scallabis/Santarém, where non-residual pieces are dated between 50 and $25 \mathrm{BC}$ (Almeida 2008: 134) in phase $1 B / 1 C$ of this site, in contexts including also Ovoid 1. At Mesas do Castelinho (Almodôvar, Portugal) were attested several fragments in contexts dating from the mid-1st century $\mathrm{BC}$ to mid1st $\mathrm{AD}$. It is evident that at least the latter are residual (Parreira 2009: 72). ${ }^{12}$ One of the most complete pieces of an Ovoid 5 from Mesas do Castelinho has already been published by C. Fabião (2001: 682, fig. 1.2), but at the time it was considered an Ovoid 1. Another example was only recently studied (Parreira 2009: Est. XXIV, no. 229). Although it was there considered to be of a Baetican coastal fabric (type 2), the clay rather seems to be the aforementioned whitish one related to the regional everyday ceramics of the lower Guadalquivir: the most frequently encountered in the specimens of this form, it can yet be confused at first sight with the Cadiz pastes. The morphology of the handle tells the same story: subrounded in section and with a slight dorsal depression rather than a real groove, this format is frequently found in the products of the Guadalquivir valley. ${ }^{13}$

A similar handle can be found on the complete Ovoid 5 amphorae from the wreck of Illes Formigues I (Martín Menéndez 2008: 108), dated towards the middle of the 1 st century BC, where this vase type was documented together with Ovoid 4 of the Guadalquivir, Gaditan Ovoid and also ovoid Tarraconensis types. Somewhat deeper is the groove on one specimen (the upper third in the figure) from Colonia San Jordi (Mallorca) (Guerrero Ayuso 1987: 161, fig. 16.1) and again on the complete specimen illustrated from the wreck Cala Bona I (Martín Menéndez 2008: 116), being shipped together with Ovoid amphorae from Cadiz area and some Guadalquivir Ovoid 4.

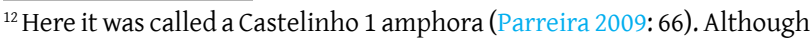
the individualisation of the type (to prevent confusion with any other Baetican type) is understandable, it is not necessary to give it a new denomination, especially one derived from a settlement in which the type was not produced.

${ }^{13}$ In the area of the current La Caleta beach in the urban centre of Cádiz, the presence of several ovoid types has recently been confirmed within a mixed group from private collections and confiscated pieces. The ovoid ones of this set are produced both locally and in the Guadalquivir valley. Among them is the upper part of an Ovoid 5 (Sáez Romero, González Cesteros and Higueras-Milena Castellano 2016: no. 17). Unfortunately, this material does not yield any chronological data as it lacks any archaeological context.
} 


$$
\begin{aligned}
& 1 ! d \\
& \because \text { d } \\
& 1111
\end{aligned}
$$


A fragment from Castro Marim (Portugal), classified as Dressel 12 (Viegas 20011: Est 104, no. 1332) presents a slightly tapering neck. Such exemplars are also documented at Santarém (Portugal) (Almeida 2008: 128, fig. 50, no. 3943); Lixus, systematically classified as LC67 (=Sala 1) (Izquierdo Peraile et al. 2001: fig. 3, 1033-780 and 1033-958; Bonet Rosado et al. 2005: 2022-1344 and 20221370), all from the middle Mauritanian period (80/50 BC-15 AD); in the Spanish south-eastern region (Molina Vidal 1995: 424, Lámina II, no. 16-17); and perhaps in Baelo Claudia (Domergue 1973: 48, fig. 14, no. 1811).

To those identified in Hispania Citerior, must be added those now catalogued by D. Mateo Corredor and J. Molina Vidal (in this volume; cf. also Mateo Corredor 2016). In Citerior, the oldest dating piece is that from Emporiae/ Ampurias (Aquilué Abadias et al. 2008), dated around 50 BC (cf. Mateo Corredor and Molina Vidal in this volume). As with Ovoid 4, Ovoid 5 is more frequent in the south of Citerior than in the north.

For their content(s), just as for most of the late Republican ovoid types previously presented, any determination is compromised by two major factors: the absence of any direct pointers, whether remains of contents or tituli, and an unawareness of the specific area of its production and workshops, but this second point could be about to change due to some new discoveries (vide infra). However, once again, their morphology and typological affinities with other South Italic types argue their preferential use as containers for the transport of oil. But they still could have served as containers for wine or preserves of other foods - as has already been proposed on several occasions for type Ovoid 1 (Fabião 2001: 673; Almeida 2008: 194-195; García Vargas 2001; García Vargas, Almeida and González Cesteros 2011: 214216). Another possibility to bear in mind is that they could have been used for different contents, depending on their area of production.

Summarizing then, the current archaeological evidence suggests a date within the central decades of the 1st century $\mathrm{BC}$, especially in the third quarter of the century, although a possible example at Dangstetten, occupied between 15-9 BC (Ehmig 2010: Taf. 15, 449-058-1), could indicate a continued 'market' presence to at least the middle of the last quarter of that century. The distribution of Ovoid 5 type is similar to that known for other products of the Guadalquivir valley, with 'demonstrated success' in the markets of the Atlantic coast of Morocco and the Atlantic coast of the Iberian Peninsula. It may have had some degree of penetration into the Mediterranean markets, to judge from its presence on the maritime 'redistribution' routes on the north-east coast of the peninsular and again in terrestrial ones in the Balearic Islands (Colonia de Sant Jordi: Guerrero Ayuso 1987). The probable rim fragment of Dangstetten would testify also to its export, even if at a reduced scale and only at the end of its life-cycle, to the military 'markets' of central Europe.

\subsection{Ovoid 6}

In Ovoid 6 we have one of the Guadalquivir Republican types where the influence of the amphorae produced in the Italian Adriatic region is most evident, perhaps due to their widespread distribution. The typological importance of this form derives from the fact that it is the first type from Hispania Ulterior to be considered exclusively an olive oil container with a completely Romanised morphology.

Fabião (1989: 73-74) had named the type Class 24, following the typology of Peacock and Williams (1986: 134-135) and believing that it was a form comparable to Oberaden 83, thus a predecessor form of Dressel 20. Subsequently, one of the present authors considered it to be a clearly autonomous type, namely Ovoid 6, separate in dating and form from Oberaden 83 (=Ovoid 7) (cf. Almeida 2008: 145147; García Vargas, Almeida and González Cesteros 2011: 228-235, 2016b). This in turn meant that a pre-Augustan form (Ovoid 6) had to be differentiated from an already clearly accepted Augustan form (Ovoid 7/Oberaden 83) within the south-Hispanic olive oil amphorae series, prior to Dressel 20.

With this in mind, we currently believe that both Ovoid 6 and 7 and the later Haltern 71 should all be clearly separated in concept and name alike from Dressel 20. Although the latter two do have some characteristics in common with their predecessors, they should nonetheless be treated as separate types. Thus, it is no longer appropriate to call them Dressel 20A, Dressel 20 'precocious', 'Dressel 20 archaic', nor even Dressel 19. This epistemological principle is already followed and shared by other researchers who recognise the relevance of treating independently the forms extant prior to the full standardisation of Dressel 20 in the TiberianClaudian era (Berni Millet 2008: 57-58; forthcoming). Any perseverance in including the late Republican type (Ovoid 6) and its successors (Ovoid 7/Oberaden 83, first, and Haltern 71 , later) within the Dressel $20^{14}$ type, and the rigid maintenance of this approach, only means that the specimens of the Ovoid 6 type will continue to go unremarked and so produce distortions in the dating (cf. González Cesteros in this volume). The end result will be to mask the production and trade of Ulterior olive oil in the late Republican period.

As with other ovoid products (Ovoid 1 and Ovoid 5, for example), these amphorae were once again produced in the southern coastal area of the Iberian Peninsula. In spite of the fact that they are very close typologically, we believe that it is better to call the products of the Guadalquivir as Ovoid 6 and those of the coastal area

\footnotetext{
${ }^{14} \mathrm{Be}$ it in groups organised by shape that are considered heralds of the later imperial form, such as Group A of Martin-Kilcher (1989), or in an overarching Class, as Peacock and Williams (1986) have done. They included within their Class 24 all oil containers prior to the appearance of the Dressel 20.
} 
Class 24 , since the latter are not really any part of the family of ovoid amphorae of the Guadalquivir.

Ovoid 6 are usually characterised by a wide ovoid body similar to that of Ovoid 7 (Oberaden 83) - with a generally rounded profile, but with their maximum diameter lying in the upper third of the body (Almeida 2008: 145-149; García Vargas, Almeida and González Cesteros 2011: 228$232,2016 b)$. There are, though, some examples that have a body much wider than normal $(56 \mathrm{~cm}$ in the case of the first): one from Benicarló (Ribera i Lacomba and Ripolles Alegre 1977: 168 and 171, fig. 6.3), another from the excavations of Santa Perpétua de Mogoda (Barcelona), one from the La Longarina 2 deposit (Contino et al. in this volume), and probably one represented by its upper part coming from La Caleta (Cádiz) (Sáez Romero, González Cesteros and Higueras-Milena Castellano 2016: no. 20), Other specimens, such as that of Ampurias (Berni Millet 1998:28, fig. 4; Berni Millet 2008: 82) or that of the Malard deposit, next to Narbonne (Sanchez 2009: 305, fig. 238, 4), probably belong to a more advanced stage within the production of the type: here the configuration of the body and neck are indeed practically already that of the later Ovoid 7 (Oberaden 83).

The shape of the pivots can vary, but the majority have a height of $5-7 \mathrm{~cm}$ and are usually solid, with a truncatedconical profile and a slightly protruding lower part; nevertheless, this is not a strict rule and some specimens may be hollow or semi-hollow, that is to say with a small clay filling, as seems to be glimpsed in the piece from Ampurias published by P. Berni Millet (2008: 82, Fig. 28). A large number of these types of bottoms were documented at Scallabis/Santarém (Portugal) (Group III of the local study; cf. Almeida 2008: 180-186), and have been attributed to most of the ovoid types identified there.

Likewise, the neck too displays more or less commonlyheld characteristics. Such diversity as is observed is a direct consequence of the modulation of the bodies. Thus, although diameters may vary considerably, most of them are straight-sided enough and not excessively wide. In specimens such as those of Santa Perpétua de Mogoda, Cádiz La Caleta and Lomba do Canho, where the body is considerably wider at the top, a short, bitroncoconical profile results, which in turn naturally leads to the application of shorter handles that describe a marked and raised arc in their profile at the point where they connect to the neck.

The rim itself can present various profiles: some specimens are slightly sub-rounded to almond-shaped (Lomba do Canho, Santa Perpétua de Mogoda, Castro Marim, Cádiz La Caleta, some of Mesas do Castelinho or Saint-Roman-en-Gal); others are sub-rounded and everted, with the edge slightly angled and the lower part clearly separated from the neck, almost resembling thus a collar rim (Mataró, Santarém's Group IX.1 rims, some of Castro Marim and Mesas do Castelinho and other from
Saint-Roman-en-Gal). However, in most specimens the rim is usually straight on the inner face and rounded or thickened on the outside, with the lower part showing a marked slant, which clearly marks it off from the neck (Ampurias, Santarém, Faro, Castelo da Lousa, Itálica, Sevilla, Lyon-Loyasse, Lyon-Cybèle). Normally, in the later ones, the distance between the handle root and the rim is greater than that observed in Ovoid 7/Oberaden $83^{15}$ (García Vargas, Almeida and González Cesteros 2011: 230-232, figs. 22-23; 2016c).

The profile of the handles varies according to the morphology of the neck and the body, with which they are intimately related: now running parallel to the neck, now following a more open and rounded profile, inclined gently towards the neck. However, a constant element and a key aspect for their identification is the section. In all known specimens it is always oval and with a longitudinal channel, more or less pronounced, that runs along its length, and being topped by a deep finger imprint. These characteristics, common too to Ovoid 4 and to Haltern 70 , are completely absent in Ovoid 7 (Oberaden 83) and Haltern 71 types, which places the disappearance of this morphological trait in olive oil containers to the penultimate decade of the 1st century BC.

For those several Ovoid 6 exemplars that present lower necks and more 'cylindrical' bodies, characteristics closer to those defined for the Ovoid 7 (Oberaden 83), it is precisely the shape and the section of the handles, as well as the pivots, that ensures that they are not classified as such. This consideration involves certain pieces found in contexts from Lyon, such as some from Horizon 2 of the sanctuary of Cybele (Lemaître, Desbat and Maza 1998), or above all from deposit 3 of Montée de Loyasse, dated from 30-20 BC (Desbat and Lemaitre 2001).

Most of the characteristics here described as defining type Ovoid 6 demonstrate a clear affiliation with the Apulian ovoid amphorae, ${ }^{16}$ especially with some of the second phase of production of the Brindisi workshops, as is the case of types I or IV of Baldacci (1972) and type III of Apani (Palazzo 1989, 2012: 27-29), as well as those, we believe, placed mainly in the group of amphorae with the stamp M. Tuccius Galeo (Cipriano and Carre 1989: 74-77). On comparing their dates, this group, made in southern and Tyrrhenian Italy, as well as in Narbonne, seems to be produced and exported slightly after the dates of the main floruit of the Brindisian production, namely in the first half of 1st century BC. They run on down to the opening of the Augustan period, as deduced from the evidence of Giancola pottery workshop (Carre and Mattioli 2003: 460; Manacorda and Pallechi 2012).

\footnotetext{
${ }^{15}$ It can be observed that analysis of the best-known sites, with welldetermined time limits, looks to reveal a greater concentration of the last rim subtypes in contexts dated between 40/30-20 BC.

${ }^{16}$ This type may not have been produced exactly in the region of Apulia, as D. Manacorda argues (Manacorda and Pallecchi 2012: 161-162).
} 
A specimen found during the excavations of the Plaza de San Antonio in the centre of the old part of Cádiz should be emphasised, as we think it is the best example showing the south Italian connection (García Vargas, Almeida and González Cesteros 2011: fig. 22). It has a body similar to the one that Panella presents in his number 66 from Ostia (Panella 1973: 494-496, 625, fig. 2) and especially to that shown in Cipriano and Carre (1989: 75, fig. 7). However, the piece from Cadiz differs from the previous ones by ending in a small pivot. On the one hand, this seems to be an effort to imitate on a smaller scale the typical shape of the bottoms of amphorae of Greek tradition (among which we would have to include the South Italic repertoire); but on the other hand, it is hollow inside, showing, in our opinion, a feature typical of amphorae of the south-Hispanic Punic tradition. Likewise, the handle profile is gently inclined in towards the neck and in section shows the characteristic dorsal groove of other products from the Guadalquivir valley (almost as a sort of trademark). It is true that the upper part of the Ostia specimen and other pieces from M. Tuccius Galeo's group are taller, straighter and have a greater distance between the rim and the beginning of the handles, but if we look at other containers that we have classified as Ovoid 6, we realise that overall it has enormous parallels in its form.

Currently, the number of documented pieces belonging to type Ovoid 6, without their being excessively numerous, does indicate a significant local/regional distribution that until recently was unknown (Almeida 2008: 145146; García Vargas, Almeida and González Cesteros 2011: 234-235). This extends beyond the limits of the Iberian Peninsula, permeating the French southeast and reaching places like Narbo/Narbonne, the Lyon region and even the Swiss area where the presence of a specimen in Augusta Raurica is confirmed in a context prior to the colonial foundation (Martin-Kilcher 1999).

In places of consumption and production in Hispania Ulterior, we encounter some specimens that confirm the impressions obtained in other areas. In the workshop of Jardín de Cano, in Puerto de Santa María (Cádiz), an upper third of a body of this type is documented together with local Dressel 1C and Class 67/LC67 amphorae (López Rosendo 2008, 2010). In the bay of Algeciras, in the pottery workshop of El Rinconcillo, there are specimens of the type, though we lack the appropriate data to assign them to local productions or to imports from the Guadalquivir valley (Fernández Cacho 1995: fig. 7.12-13). Returning to the Cadiz area, the Class 24 amphorae of the workshop of Rabatún (Jerez de la Frontera, Cádiz) (García Vargas and López Rosendo 2008: 294, fig. 10, no. 9-11) have the same fabrics as the rest of the figlina productions, which endorses the idea that it is a type that was produced simultaneously in the area near the Bay of Cadiz and in the interior of the Guadalquivir. As in the case of the Ovoid 1 , the products of the Guadalquivir valley are the most numerous.
In the surroundings of the Lower Guadalquivir, it is worth mentioning the presence of some fragments of Ovoid 6 type in Augustan layers of the pottery workshop located in the plot of Doctor Fleming 25 in Carmona (García Vargas 2010: 597), a city in which it must have been produced (although there are no overfired fragments recovered), along with other major types such as Ovoid 4 and Haltern 70. In Italica, the amphora deposit from the port area containing Dressel 1, Ovoid 1, Ovoid 3 and Ovoid 4 also has a body of Ovoid 6, lacking its mouth (García Vargas 2012: fig. 7.3; García Vargas, Almeida and Fabião forthcoming), together with a complete neck of the another. Likewise, within a broad date range in the second half of the 1st century $\mathrm{BC}$ belong a residual neck from the SU 161 context in Alemanes 25 in Seville (García Vargas 2009: fig. 4.15), while shoulders with their handles from the Patio de Banderas (SU 1921, inv. no. 1702) and a rim fragment, ascribable to subtype XI.1 of Santarém (Almeida 2008: fig. 58) from the SU 1818 context of the Patio de Banderas (inv. no. 1578) must go with the third quarter of the 1st century BC (García Vargas 2012: fig. 6.5).

The distribution of Ovoid 6 type in the Iberian Peninsula has been studied very recently (cf. Almeida 2008; García Vargas, Almeida and González Cesteros 2011), and particularly updated for Hispania Citerior by D. Mateo Corredor and J. Molina Vidal (in this volume), to whose catalogue we refer. The earliest date so far for the appearance of the type in this province is the mid 1st century BC (forum of Ampurias: Tremoleda i Trilla and Castanyer i Masoliver 2013), while a substantial increase in oil imports from the Guadalquivir occurs towards the end of the 1st century BC, though carried then in Ovoid 7 amphorae (Oberaden 83).

Outside the Iberian Peninsula area, in addition to the Gallic contexts, it should be noted that North Africa could be another export destination for this type: currently within the material of the Punic-Mauritan phase II of Lixus/Larache (Aranegui Gascó 2001) some specimens of Ovoid 6 can be observed. Although the drawings in the 2001 publication did not allow us to determine whether they were late Republican ovoid types or whether they were already Ovoid 7 (Oberaden 83), as seemed to be the case, later finds did testify to the presence of the older type (Bonet Rosado et al. 2005: 122-123, fig. 16).

We do not have any truly conclusive data on when these amphorae began to be produced. The documentation presented by different contexts of production and importation in the Cadiz area seems to be the best avenue of approach to the question of the start of production (García Vargas, Almeida and González Cesteros 2011: 235; cf. 2016c). On the other hand, the very fact that they seem to arise from an evolution of the imitations of some of the main oil amphorae of southern Italy suggests that they should not have been too distant in time from the prototypes, whose greatest diffusion can be found in the second and third quarter of the first century BC. For these 


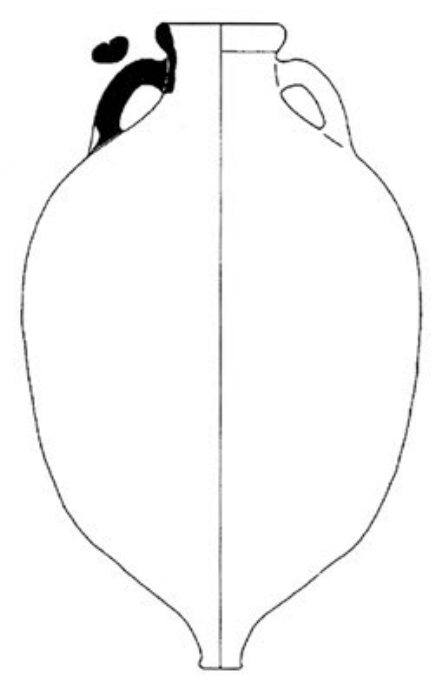

Sta. Perpétua de Mogoda

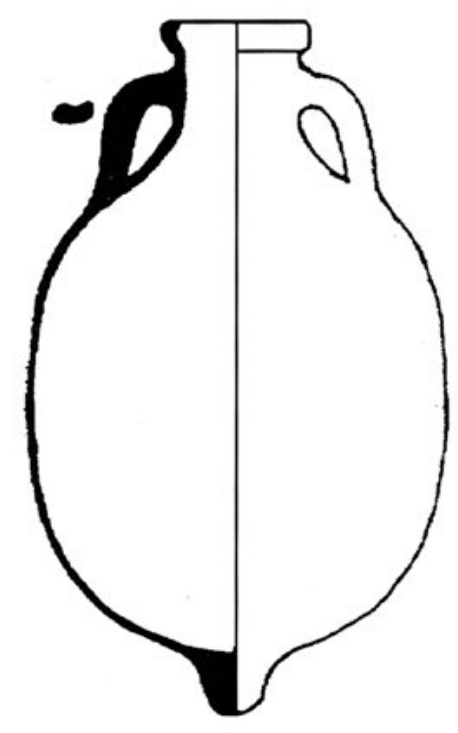

Islas Columbretes
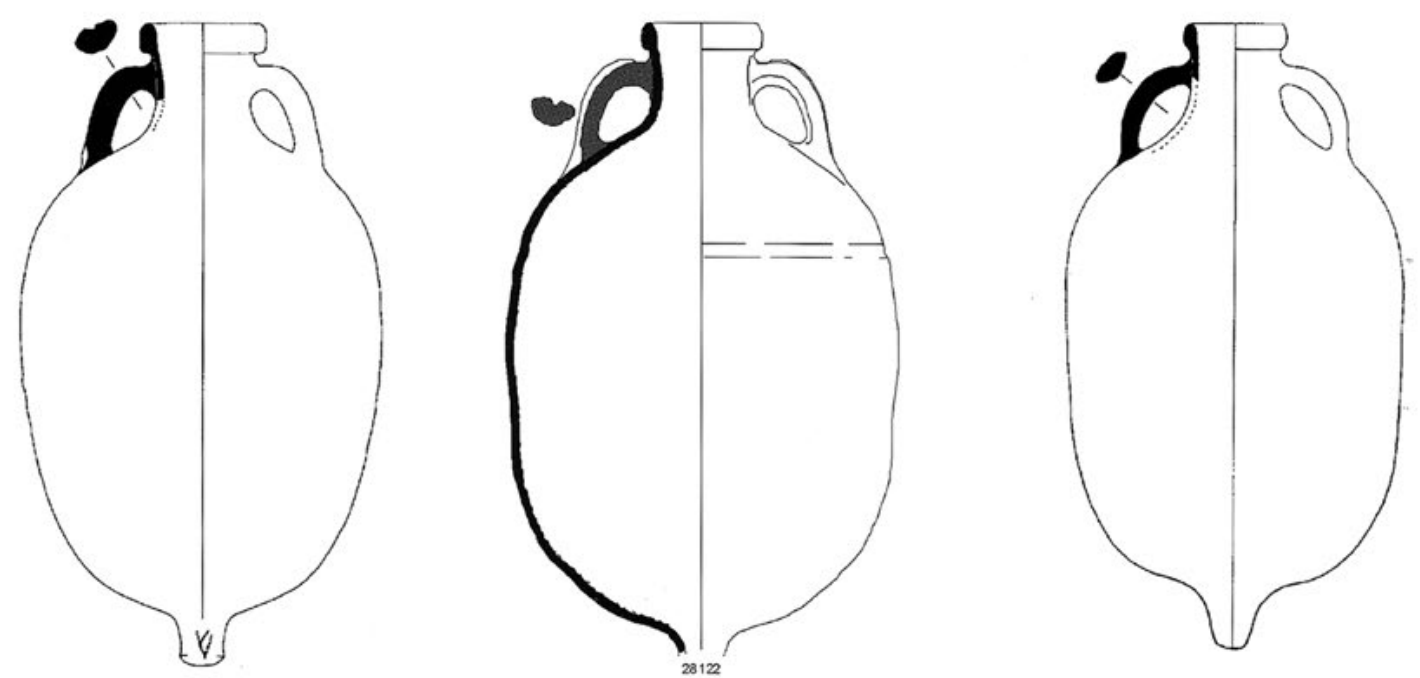

Ampurias

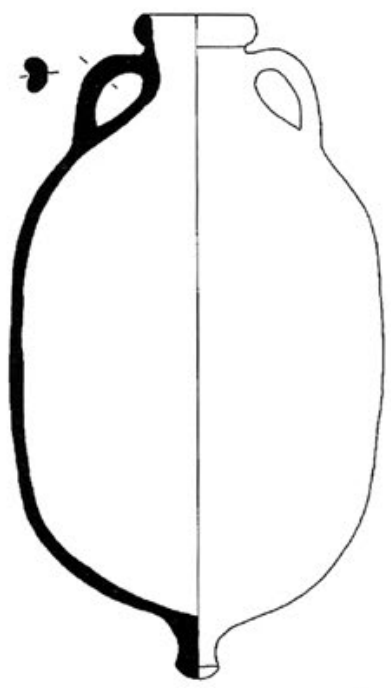

Cartagena



Malard

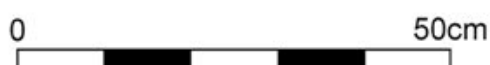

Mataró

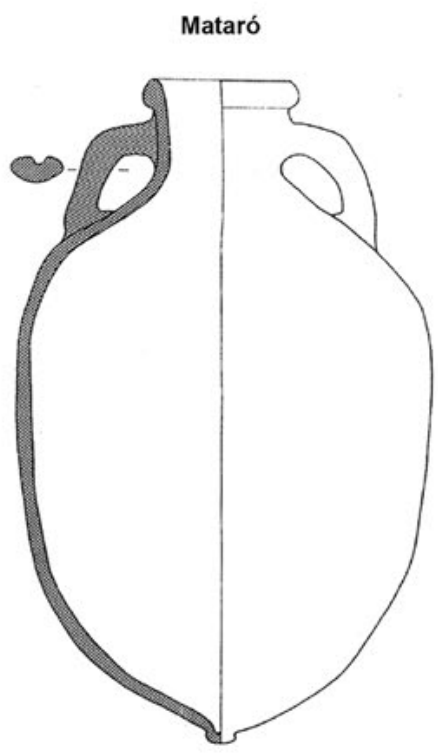

PI. San Antonio

$\mathrm{cm}$

Figure 13. OVOID 6. COMPLETE AMPHORAE OF THE TYPE. 


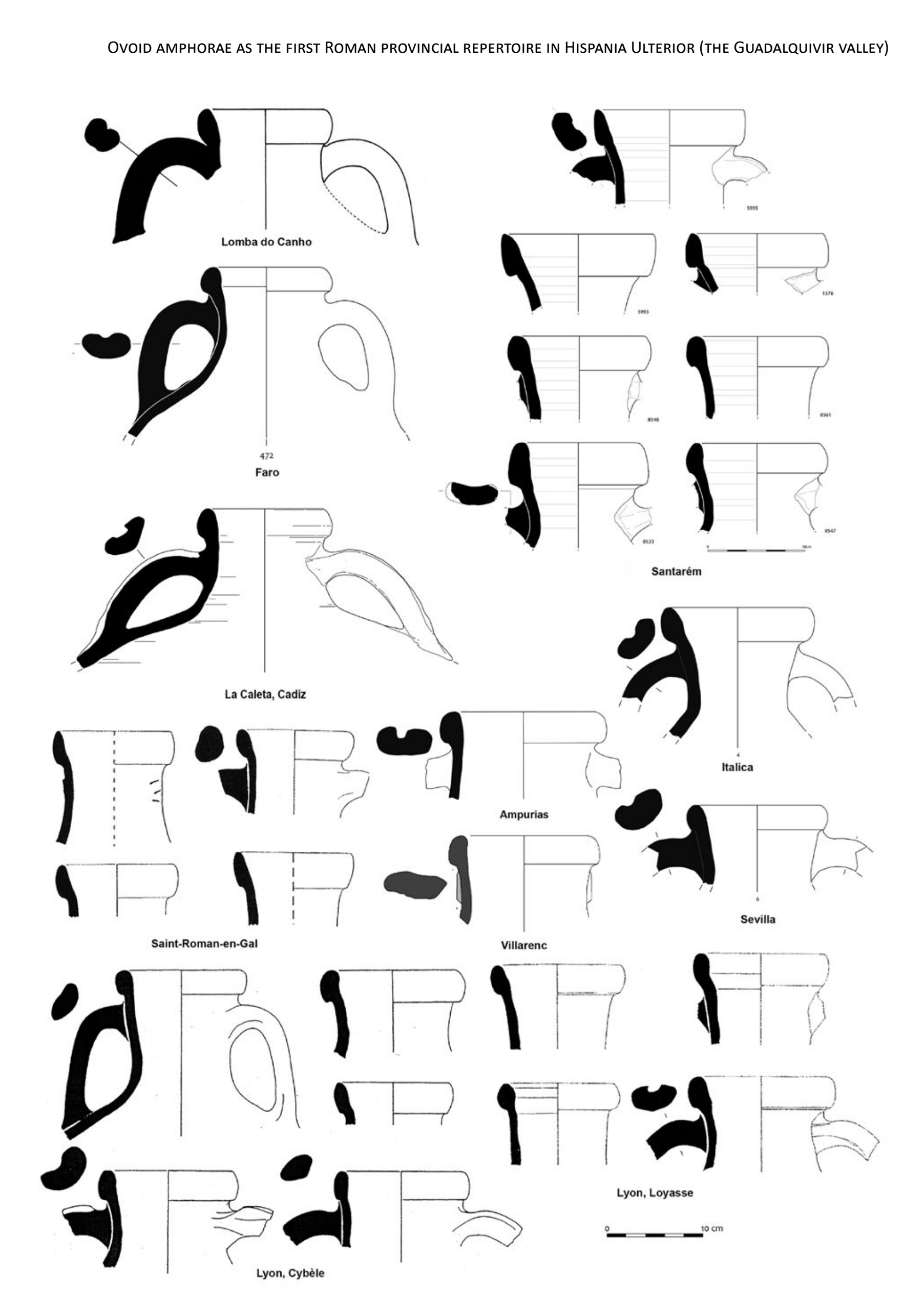


reasons, we believe it convenient to place the beginning of the production of Ovoid 6 at some time in the second quarter of the first century BC, probably as a direct result of the needs of the large number of Roman troops that passed through the Iberian Peninsula, from the civil wars on through to the conquest of northern Hispania after the Cantabrian wars of Augustus.

Fewer problems are presented in assessing the final date of production of Ovoid 6 type: this is to be set in the third decade, or rather at the beginning of the second, before the $\mathrm{BC} / \mathrm{AD}$ watershed, since from then on they seem to be replaced by the Ovoid 7 (Oberaden 83). Perhaps it is more exact to say that is in the early Augustan years that we witness the last phase of its formal development and its translation into the Ovoid 7 (Oberaden 83), in parallel with the conversion from Ovoid 4 to Haltern 70 (vide supra).

It should be noted that Ovoid 6 possessed a considerable range in its shape, more pronounced than in other types of south-Hispanic ovoid amphorae, which is somewhat surprising if we consider that diffusion abroad and formal standardisation tend to go hand in hand. In pieces from such as Ampurias (Berni Millet 2008: 82), Malard (Anteas 1993: 86-87), Cartagena and Mataró (Pérez Suñé and Revilla Calvo 2001: 596), a degree of development in shape seems to be discernible towards the final days of production of the type, which reveals a shift in shape away from the Apulian models, so marking its evolution towards the characteristic Hispanic olive oil containers of the Augustan era. These aspects can be best appreciated in the body and handles (cf. Anteas 1993: 86-87; Sanchez 2009: 305, for the copy of Malard, Narbonne; Lemaitre, Desbat and Maza 1998: fig. 9, 1, for a copy of the Sanctuary of Cybele in Lyon).
The presence of Ovoid 6 outside the Iberian Peninsula, limited in particular to the southern area of Gaul and the Rhone river axis, as well as to Ostia and Rome (Contino et al. in this volume), already foreshadows the move that will develop later on with Augustus, opening up what will be the most important markets for the products of the Guadalquivir valley during the Roman period.

\subsection{Ovoid 7 (Oberaden 83)}

Loeschke introduced this form in his work on the material of the German settlement of Oberaden (Loeschke 1942), and it is from that same place that it receives its initial name, being classified by the German researcher with the number 83 in the table of ceramic material from there. However, the same author placed them with the Baetican olive oil amphorae of Haltern that he had studied previously and to which he had given the number 71 within his series there for the ceramic types (Loeschke 1909). This created some confusion that has prevailed until relatively recently: some researchers insist on prolonging the situation, which is regrettable in that there is a consequent loss of information at a detailed level. The chronological framework itself of the Oberaden camp, with a precise range from $11 \mathrm{BC}$ to 8-7 $\mathrm{BC}$, defines the period of life of the Oberaden 83 form, which must have been in play for the last two decades before the Christian era (García Vargas, Almeida and González Cesteros 2011; González Cesteros and Tremmel 2011-2012; González Cesteros 2014; González Cesteros, García Vargas and Almeida 2016; González Cesteros and Almeida 2017).

Subsequently, as a result of a recent revision, this form was included in Peacock and Williams Class 24 (1986: 134135) and classified as Dressel 20 variant A by P. Berni Millet
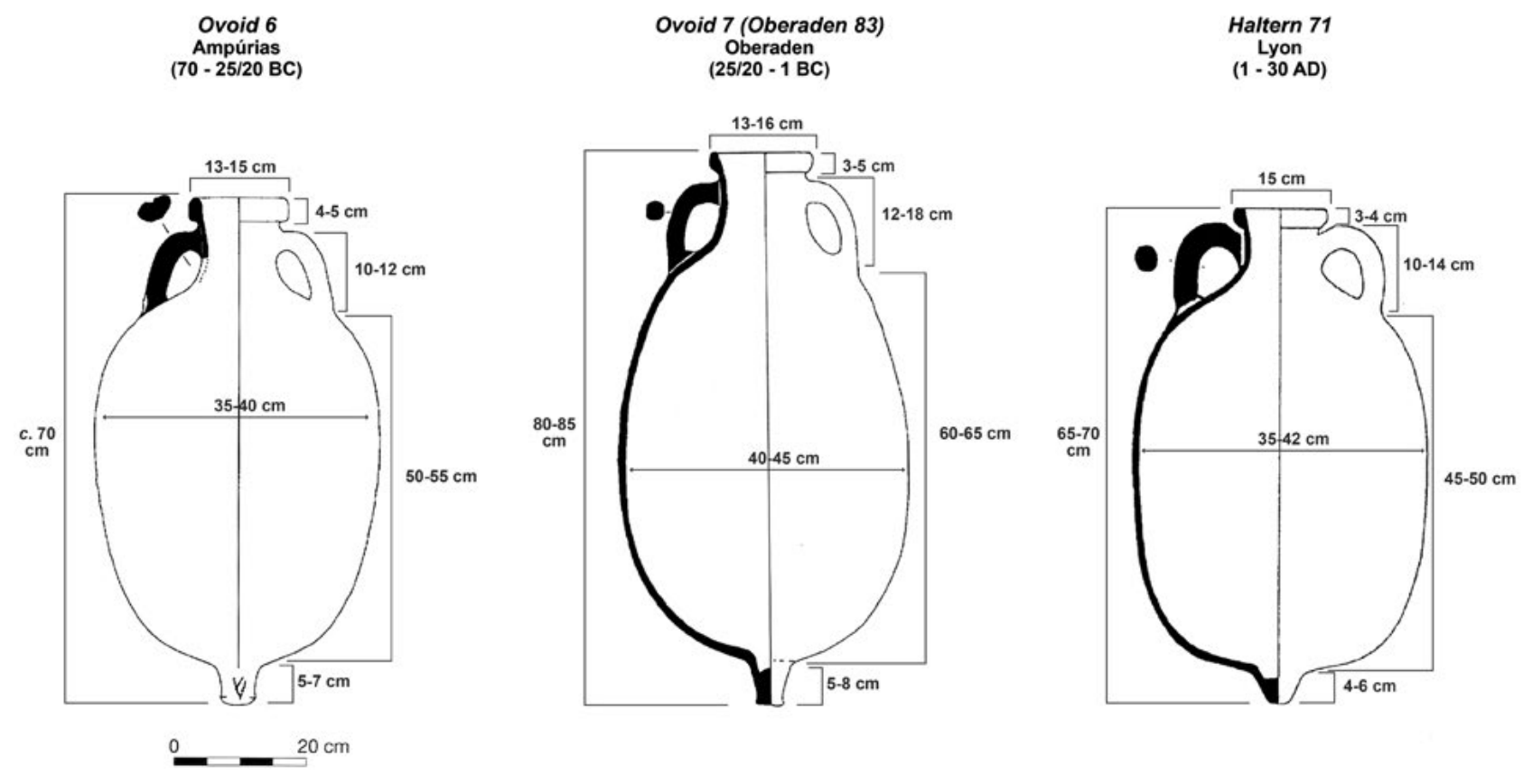

Figure 15. OUtLINE OF THE EVOLUTION FROM OVOID 6 to HALTERN 71. 

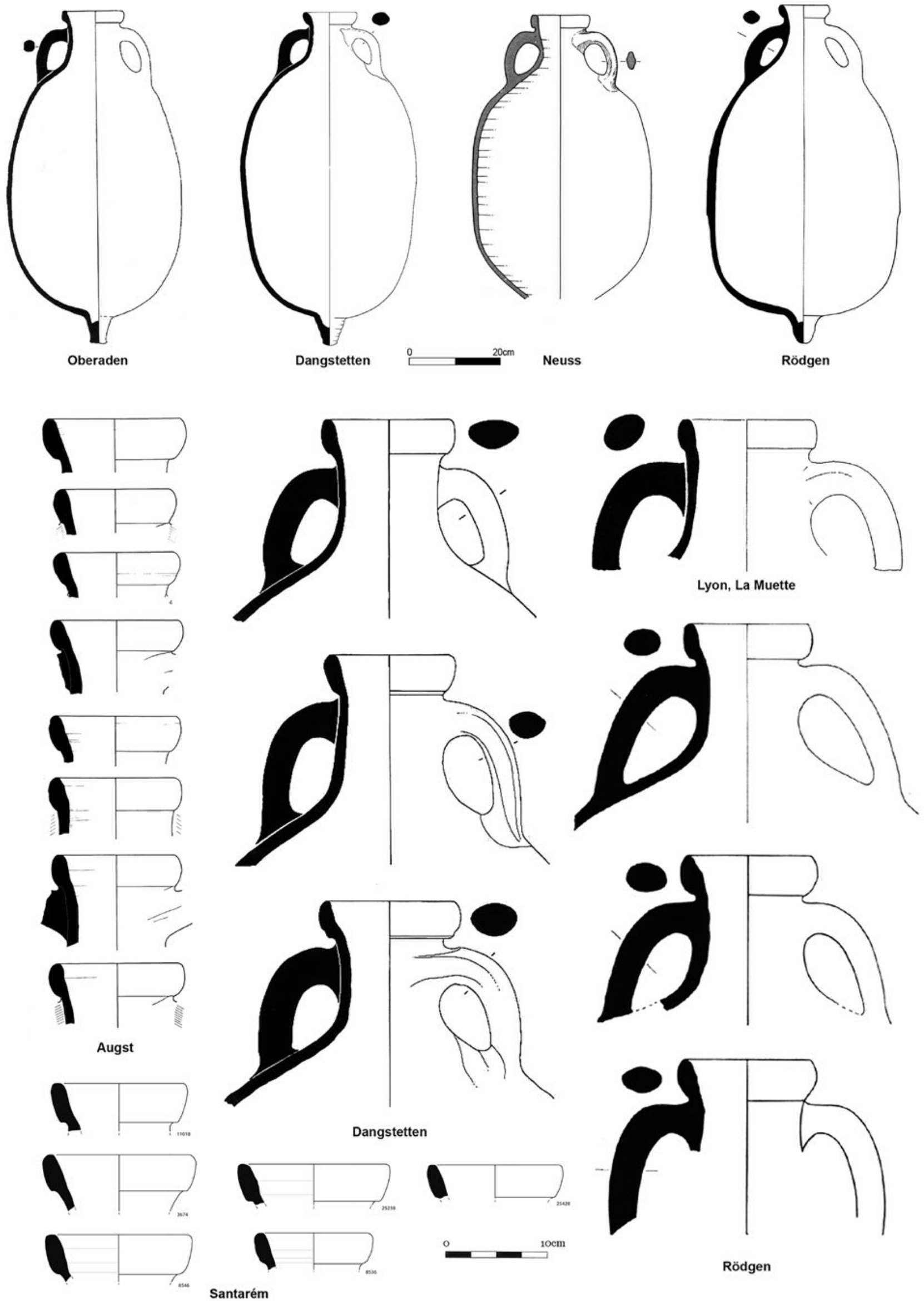

Santarém

Figure 16. OVoid 7. Complete specimen (ABOVE) AND fRAgments ATtRiButable to the tYPe (Below). 
(1998: 26-28). A decade ago, one of the present authors was already suggesting its inclusion in the typology of the ovoid forms of the Guadalquivir. Although it was an Imperial form, it represented the last stage in the ovoid story that preceded the globular form Dressel 20, and should therefore be treated autonomously (Almeida 2008: 150-152). P. Berni Millet (forthcoming) corroborates and reinforces this stance, discouraging the use of any terminology other than Oberaden 83 or Ovoid 7 of the Guadalquivir, since it is not yet a Dressel 20 type amphora proper, but rather one of its typological antecedents, and not even the immediate one, since between these two forms lies the Haltern 71 type.

In its form, the type Ovoid 7 (Oberaden 83) is an amphora that shows a marked heterogeneity, maybe due to the fact that it is evolving towards a certain standardisation. In fact, a satisfactory regularisation of the Baetican olive oil amphorae will not be achieved until the 30 s of the 1 st century $\mathrm{AD}$, with the appearance of the canonical Dressel 20 (Werff 1984: 355; Berni Millet 2008: 59, forthcoming; González Cesteros 2014; González Cesteros and Almeida 2017: 55).

Broadly speaking, this type can be described as an amphora still with an oval body, although sometimes tending to the cylindrical, with an average height of more than $70 \mathrm{~cm}$. In its lower part, it presents a small semi-solid pivot (it does not exceed $8 \mathrm{~cm}$ in height), which in its lowest external part is semi-flat with rounded edges, and on the inside has the characteristic button or clay pellet of the productions of the Guadalquivir. It sometimes comes with grafiti ante cocturam. These 'identity marks' seem to be a common characteristic of the Guadalquivir workshops during the Augustan period, as evidenced by the fact that they also appear on Haltern 70 and Haltern 71.

In its upper part, the amphora is characterised by having a neck more or less straight, which ends up opening gently into a slightly everted rim. The diameter of the mouth is usually between 13 and $15 \mathrm{~cm}$, although it is true that there are few specimens that can exceed $15 \mathrm{~cm}$. The rim usually has a height above $3 \mathrm{~cm}$, but without exceeding $4.5-5 \mathrm{~cm}$. In shape, it is lanceolate or slightly almond-rim shaped, with the upper part rounded, both inside and out. Although there are specimens with quite straight rims and slightly everted necks, sometimes straighter necks with more prominent rims are also observed. In general terms, the most common rims in Ovoid 7 amphorae (Oberaden 83) are the first ones, coinciding with the rim types IX.2 from Santarém (Almeida 2008: 144, table 5).

The handles are another important element when it comes characterising the Ovoid 7 (Oberaden 83): one can distinguish them from previous and subsequent olive oil types (Ovoid 6 and Haltern 71, respectively). They usually start just below the rim, making a smooth step with it, and have a more or less rounded profile. If we compare them with the handles of the Haltern 71 or Dressel 20, they are not excessively massive, presenting a generally oval section, sometimes rounded, and without a groove. These are traits that distinguish this type perfectly. In the current state of investigation, we believe that Ovoid 7 (Oberaden 83) began to be produced roughly at the time of the installation of the first military camps on the Rhine border, that is, around 20 BC (García Vargas, Almeida and González Cesteros 2011: 237-238; González Cesteros 2014; González Cesteros, García Vargas and Almeida 2016).

Although they are documented in some profusion on the eastern peninsular coastline (cf. Mateo Corredor and Molina Vidal in this volume), their main import area seems to have been the German camps, where they are found in very high percentages, as shown by Oberaden (González Cesteros and Tremmel 2011-2012), Neuss (González Cesteros and Berni Millet 2018), Dangstetten (Ehmig 2007, 2010), Vindonissa (Martin-Kilcher 2003) and Rödgen (Schönberger and Simon 1976). Likewise, some amphorae classified by S. Martin-Kilcher within group A of the Augustan olive oil types (1987: 53) belong to this form. These are pieces imported at the beginning of the Augusta Raurica colony, founded around 15 BC. However, most of the amphorae of this Augustan group are already the Haltern 71 form and will probably have arrived at the camp from the BC/AD changeover and onwards.

The evidence from the Rhône deposits, the centres of consumption and the transit axis of these olive oil containers to the Rhine camps combine to present a consistent story. While a large part of the amphorae of the Cybele sanctuary from Lyon and those from Loyasse, also in Lyon, are of the type Ovoid 6, yet other pieces from the pottery workshop of La Muette $(20 \mathrm{BC}-0)$ or from the Horizon 1 of Saint-Romain-en-Gal (30/20-15 BC) (Desbat and Lemaître 2001: 806-811) are already Ovoid 7 (Oberaden 83). These amphorae clearly show the continuation, into Augustan times, of the first and earlier imports of Baetican olive oil: this trade is observed from immediately preceding the foundation of Lyon as a Roman colony in $43 \mathrm{BC}$. The settlement goes on to become a civil nucleus of the first rank in its very important role as capital of Galia Lugdunensis (27 BC) and as the main axis of communications by road and river into the interior of Gaul and northern Europe.

Although it seems that the main destination of the Ovoid 7 (Oberaden 83) amphorae outside the Iberian Peninsula was the German border camps, they are also documented in Augustan contexts in Italy, such as La Longarina (Ostia), where up to three complete specimens are indicated (Hesnard 1980; Contino et al. in this volume). At least 36 fragmentary specimens come from small trenches in the Porticus Aemilia of Testaccio (Rome), although they do so as residual material in contexts from the end of the 1st century or as early in the 2 nd century AD (Contino et al. in this volume).

It can therefore be said that the Ovoid 7 (Oberaden 83) is the first amphora type to document the massive 


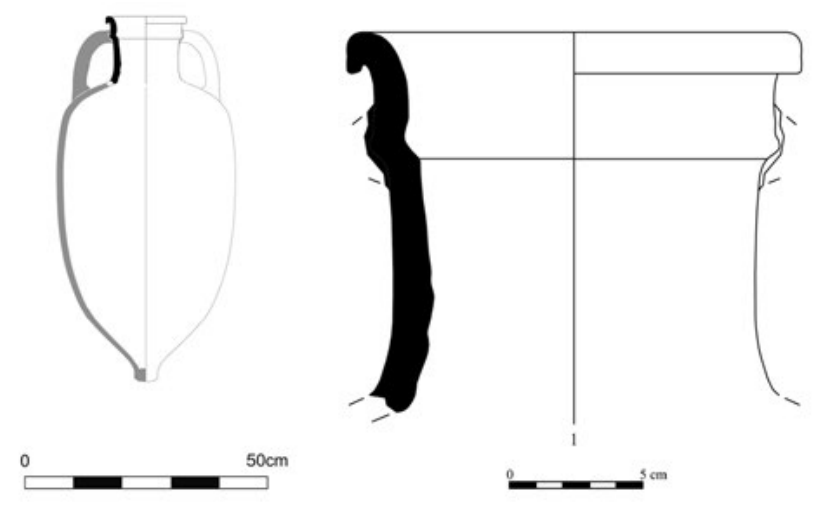

\section{FIGURE 17. OVOID 8. PROTOTYPE PROPOSAL AND FRAGMENT FROM PATIO DE BANDERAS OF THE ALCAZAR OF SEVILLE.}

export of Baetican olive oil outside the Iberian Peninsula, to destinations that will remain the main markets for Baetican oil during the entire Imperial period. Their high numbers in the Rhine basin and along its main tributary rivers, especially the Lippe, clearly indicate the directness of the link existing between the production of Baetican oil and its export to the army in the phase of conquest of Germania.

\section{8. Ovoid 8}

The Ovoid 8 type is a recently proposed one, based on some incomplete copies from Patio de Banderas del Real Alcázar de Sevilla (García Vargas, Almeida and González Cesteros 2011: 205). The rim and neck specimens recovered are related to the construction phase of the complex of opus africanum buildings interpreted as the port horrea. These construction filling layers are dated between 50 and $25 \mathrm{BC}$.

This particular form made in the fabrics of the Valley of the Guadalquivir displays certain similarities with the type Ovoid 5, but yet does not fit with any of the types recognised in this repertoire. Accordingly, it is appropriate to grant them a new designation (García Vargas 2012: 190).

The simple system of continuing the seriation established for the several minor amphora types of the Guadalquivir has been adopted, following on from the evidence set forth for Santarém (Almeida 2008). This had ended with type 7 (Oberaden 83), to which are now added two new forms: types 8 and 9, as well as a third type that looks like an imitation of the type Lamboglia 2. This last, even though not being an ovoid container, has been catalogued as Type 10 (García Vargas, Almeida and González Cesteros 2011: 206-207).

All these types are represented, for the moment, mostly by specimens recovered at Patio de Banderas, but a few more are known in places of consumption on the Lusitanian Atlantic façade. We believe that their 'morphological personality' is strong enough to justify their assignment to new types of which, however, the full profile is not yet known.

A fragment of a rim and neck of an Ovoid 8 from the aforementioned excavations in Seville (SU 1692) has the following peculiarities of form: the neck profile is similar to that of the products defined as Ovoid 5 (vide supra), but differs in the shape of the rim and lacks the traditional moulding or 'collar', so characteristic of both Ovoid 1 and Ovoid 5. In fact, for type Ovoid 8 what at first sight could be considered as the moulding or medial ring of the neck turns out not to be a real moulding but the lower part of the rim; the upper part is given a flaring rim of triangular section, and stands much less high than the typical Ovoid 5 one does. In addition, the handles are attached to the lower part of the rim, so marking a difference compared with amphorae of the Ovoid 5 type, whose handles are always integrated into the neck below the moulding ring. A second piece of the Patio Banderas (SU 2080) confirms this observation.

The absence of complete specimens prevents us from describing this form in more detail. Likewise, the scarcity of known specimens inhibits inferring any valid conclusions regarding the diffusion and period of production, which, however, given its low level of presence, could not have been very broad or long. In its day, it belonged to a group of containers that enjoyed but a short life and little success in the 'markets' (García Vargas, Almeida and González Cesteros 2011: 200-211).

\subsection{Ovoid 9}

Two complete necks with their rims, handles and shoulders, from layers stratigraphically related to the opus africanum building in the excavation of the Patio de Banderas from Seville (50-25 BC), have also proved difficult to assign according to the typologies in use, although it is unquestionable, from the colour and macroscopic aspect of their fabrics, that they belong to another Republican type of the Guadalquivir family.

The pieces that can be ascribed to what is interpreted and classified as Ovoid 9 have a subtriangular high rim with a small protrusion at both its upper and lower edges on the outside, giving it the appearance somewhat of a spool or pulley. The shoulders are straight and it is thus likely that the ovoid profile resembles such as that of the Ovoid 5 , given the marked angle they describe with respect to the base of the neck. The handles of both specimens from Seville are very fragmentary, although the preserved part of one suggests the presence of a slight longitudinal groove. Accordingly, we place these fragments among the regional amphorae of an ovoid morphology (García Vargas, Almeida and González Cesteros 2011: 206; García Vargas 2012: 190-194). 

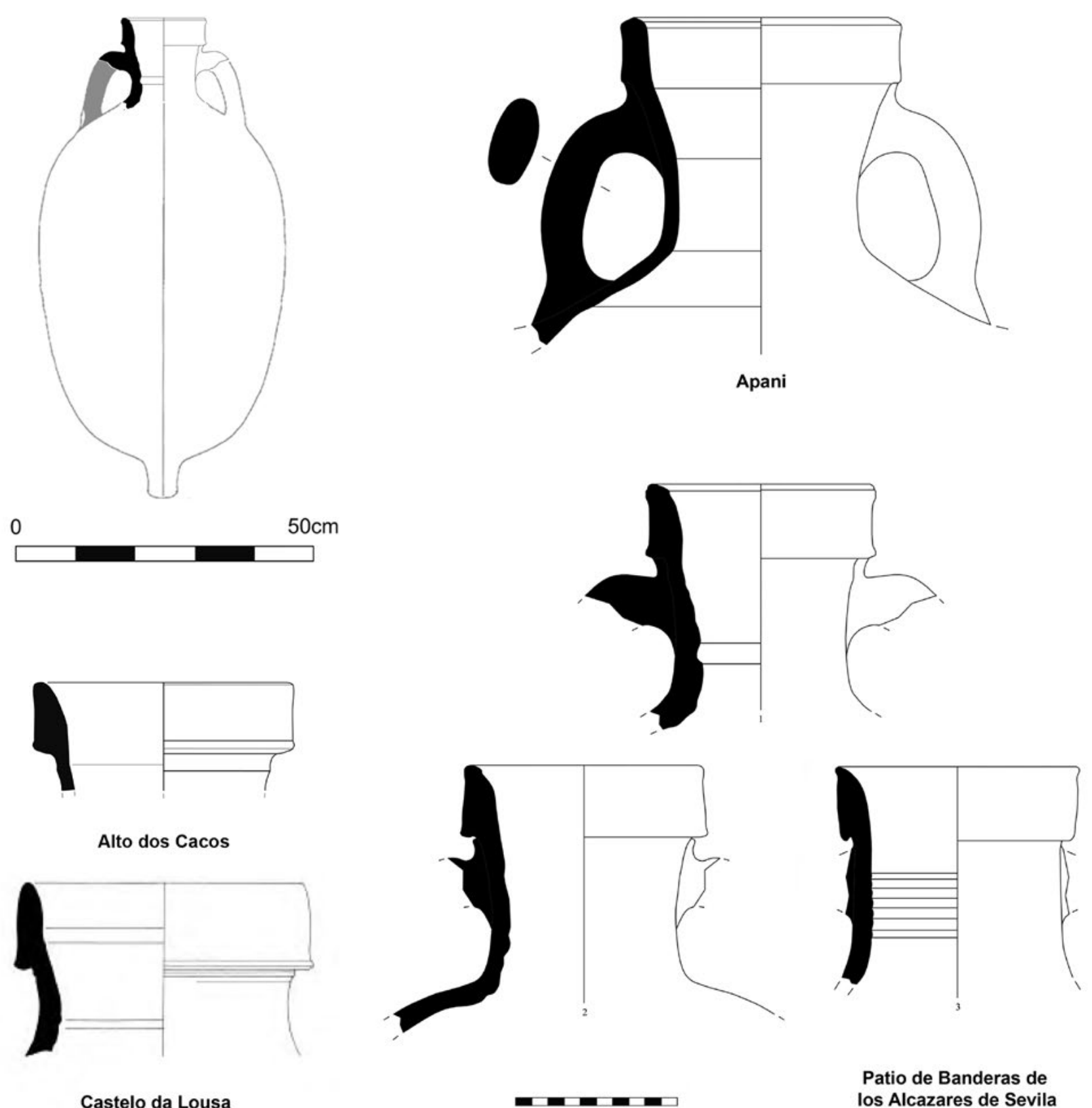

Castelo da Lousa los Alcazares de Sevila

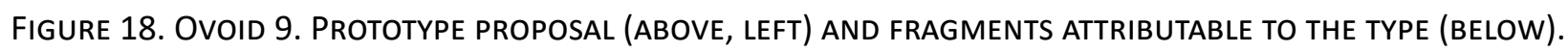

An example, very similar to those of Hispalis/Sevilla and recently published, comes from Alto dos Cacos (Almeirim, Portugal), a site with obvious military connotations, located very close to the city of Scallabis/Santarém, but on the opposite bank of the Tagus river (García Vargas, Almeida and González Cesteros 2011: 207, fig. 9; Almeida and Pimenta 2018). A fragment of rim without handles from the SU 1692 context of the Patio de Banderas, and allotted the same date range, could represent an internal variant of the type (García Vargas 2012: 190) which, like all other ovoid types, would be sure to display some degree of intrinsic variability. It has a less internally thickened rim, with a slightly concave surface to its external face, with a short cylindrical neck and the upper root of the handles just like the rest of the Ovoid 9 pieces (García Vargas, Almeida and
González Cesteros 2011: 206). Very similar to this is a rim fragment from Castelo da Lousa (Portugal), dated between $40 \mathrm{BC}$ and the Augustan period, although classified as Dressel 12 (Morais 2010: 214, Estampa XXXVI.82).

A fairly close parallel for the Ovoid 9 type can be found once again in Apulia, namely variant B of form VII of Apani workshop (Palazzo 1988: 112-113, 1989: 549 and 553, 2012: 24), a form that began at the end of the 2 nd century BC. As with the Ovoid 8 type, the absence of complete vessels makes it impossible to describe this shape in more detail. The type belongs to the group of short-life containers that saw little success in the 'markets' (García Vargas, Almeida and González Cesteros 2011:200-211) for reasons similar to those of Ovoid 8 (vide supra). 


\section{Epigraphy on Guadalquivir Ovoid amphorae}

The epigraphic evidence on ovoid amphorae from the Guadalquivir valley is very scarce at the present, and that includes the entire Guadalquivir valley itself, an area where the Imperial production actually presents an extraordinary quantity of epigraphic material, including stamps, ink inscriptions and graffiti (Berni Millet 2008). A different situation seems to apply though to the Tarraconensis productions (Berni Millet and Miró Canals 2013: 65-67), even though a high number of the stamped examples belongs to the form Tarraconensis $1 \mathrm{E}$, a transitional type to the Pascual 1 that we cannot consider as an ovoid type (Miró Canals and Járrega Domínguez in this volume; González Cesteros in this volume). This variance is also seen if comparisons are made with other non-Hispanic products, especially with the early Brindisian amphorae that present a very rich epigraphic documentation.

In the last years though some interesting finds have been brought to light. The discovery of a family of stamps in Iberian Peninsula contexts and dated from the last quarter of the 1st century $\mathrm{BC}$ confirms that the rich epigraphical system of the Imperial amphorae of the Guadalquivir valley has its forerunners even as far back as the second half of the 1st century BC.

As accurately observed by Berni Millet (2008), besides the stamps and tituli picti, the first epigraphical signs documented on Guadalquivir amphorae were graffiti ante cocturam. These marks, made in a random manner on the spikes of the amphorae - as seen in that on an Ovoid 6 type from Ampurias Museum (Berni Millet 1998: fig. 19, no. 5-6) and in many others from the assemblage of Santarém/Scallabis (Almeida 2008: 184-187, 190) represent evidence for organised and specialised potting within the framework of a pre-industrial economy. This kind of graffiti in pede, usually composed of just one single letter, will become fairly common on all types produced in the Guadalquivir valley in early Imperial times (Berni Millet forthcoming).

\subsection{Stamps}

Today, among the known stamps, the apparently oldest is one on an Ovoid 6 amphora, found on the surface at the site of Alto dos Cacos (Almeirim, Portugal), near the city of Santarém/Scallabis and whose origin is attributed to a military installation dated in the third quarter of the 1st century BC (Pimenta, Mendes and Henriques 2012; Almeida and Pimenta 2018: 26 and fig. 11, no. 12). Unfortunately it is a stamp that can hardly be read $\left|\mathrm{T}^{\wedge} \mathrm{E}^{\prime \prime}[---]\right|$, inserted in an oval cartouche placed on the neck (Pimenta, Mendes and Henriques 2012; Fabião et al. 2016: no. 77 and Estampa 8; Almeida and Pimenta 2018). Both these characteristics are certainly peculiar. However, it is interesting to observe in some very few specimens of ovoid morphology, presumably from southern Italy like the one recovered in the Castro of Villasviejas de Tamuja (Cáceres, Spain), a stamp on the neck and an oval cartouche can be made out (Hernández Hernández 1993: fig. 3).

The most abundant stamp documented in morphologies that we can describe as 'ancient' and ovoid, and the best indicator of the birth and establishment of an epigraphic tradition in the amphora production of the Guadalquivir valley, is undoubtedly the L.HORATI stamp (Fabião et al. 2016, forthcoming).

To the first exemplars of this stamp recovered at Mahón (Balearic Islands) and Santa Tecla and Castro de Vigo (Galicia) were added those of Badalona and La Alcudia (Elche) (Almeida 2008: 177-178). Despite the fact that the stamp had not been read in all its development nor correctly interpreted until that moment - the reading hitherto was LHOP, LHOR, LHOT, LHOTER - the last two examples provided important data. The first piece because it was dated contextually at the time of Augustus and a little before the change from $\mathrm{BC}$ to $\mathrm{AD}$ (Comas i Solá 1997: 91, nº. 223); and the second, because the authors stated that that from the details of the handle form, the vessel was a Haltern 70 or Ovoid 6/Oberaden 83 (Márquez Villora and Molina Vidal 2001: 134, no. 28).

In the first two decades of the 21st century, subsequent to its identification and complete reading as L.HORATI on a specimen recovered in Scallabis/Santarém in contexts of the end of the 1st century $\mathrm{BC} /$ beginning of the 1st century $\mathrm{AD}$ (Almeida 2008: 177-178), the finds of this potter have multiplied in Portuguese territory: in Lisbon in the Roman theatre and in the Cloister of the Sé (Cathedral), unfortunately from medieval contexts; two more in Alto dos Cacos (Almeirim), very close to Scallabis/Santarém (cf. Fabião et al. 2016:54-57, forthcoming). The exception to this predominantly coastal and Atlantic scenario lies in a possible example in Castro de Vieito (Ponte de Lima) ${ }^{17}$ and three new ones documented at Mesas do Castelinho (Almodôvar), in the interior of Portugal, though once again in contexts dating from the final moments of the 1 st century $\mathrm{BC} /$ beginning of the 1 st century $\mathrm{AD}$.

The large concentration of specimens of this stamp in the Lower Tagus valley - in the area of Scallabis/Santarém, an important inland navigation point, and in Olisipo/Lisbon, an significant commercial outpost at the mouth of the Tagus and an first importance Atlantic port - seem to point a preferential supply to this area at a certain time (cf. Fabião et al. 2016: 117, forthcoming).

In all known cases of the HORATI stamp, it seems to be the same stamp, and even the same matrix, used to make the initial sequence L.HO and as a distinctive element the conections of the letters RATI (Fabião et al. 2016: 57, forthcoming). Unfortunately, all these cases involve only isolated fragments of a handle, so it is not possible

${ }^{17}$ It is an incomplete stamp L.H [...]|, which according to the author of the study is made on the handle of a Haltern 70 amphora (Silva 2008: 14, fig. 1.6). 
to determine with certainty the type of amphora with which they would be associated. Even so, it is possible to make some conjectures. As a general rule, the handles are short and narrow, features attributable to ovoid types, and have an oval/semi-rounded section, which in only two cases has a small longitudinal groove, or really rather a slight indentation. On the basis of these morphological characteristics, we agree with the proposal that they should be ascribed to early Augustan forms, to the Oberaden 83 or other ovoid types that coexist with it (Fabião et al. 2016: 57 and 117; Berni Millet forthcoming; Fabião et al. forthcoming).

\subsection{Ink inscriptions}

The survival of ancient ink inscriptions, regardless of the kind of surface where they were written, is a matter of hazard and luck, due to their organic nature. With amphorae, it does seem that for some types a more precise system of inscriptions has come down to us, evidence of a more organised approach to labelling. This is the case with the export on a massive scale of regulated goods, such as the Imperial olive oil amphorae of Baetica (Rodríguez Almeida 1984; Berni Millet 2008, forthcoming) or the fish-sauce amphorae from south Spain (Martínez Maganto 2000; Martin-Kilcher 2004; Lagóstena Barrios 2004; García Vargas 2012).
As emphasised previously, some years ago Fabião (1989: 66-68) commented that the Ovoid 1 type could represent the first physical evidence for the export of Baetican fish-products from the Guadalquivir valley (vide supra Ovoid 1 type). This hypothesis was mainly supported by a supposed titulus appearing on one amphora from the San Ferreol wreck by Cartagena, Spain (Mas García 1985: 205). However, the re-examination of that fragment and a more accurate reading of the wreck's publication revealed that it was the result of a misunderstanding of the original data.

Therefore, until now, we have no evidence of ink inscriptions for any of the Guadalquivir ovoid amphorae types, something that contrasts heavily with the later frequency of them on other vessels from the same geographical origin.

In the last years, though, we can document a very interesting find that could change the interpretation of the epigraphic system used with the olive oil amphorae from Baetica and help us to understand the beginning of the regulated traffic of olive oil by the Roman state. It is an exemplar of what seems to be an Ovoid 7 (Oberaden 83) found in the military camp of Neuss in the lower Rhineland (González Cesteros and Berni Millet 2018: Epigraphy no. 128; Berni Millet forthcoming). This piece
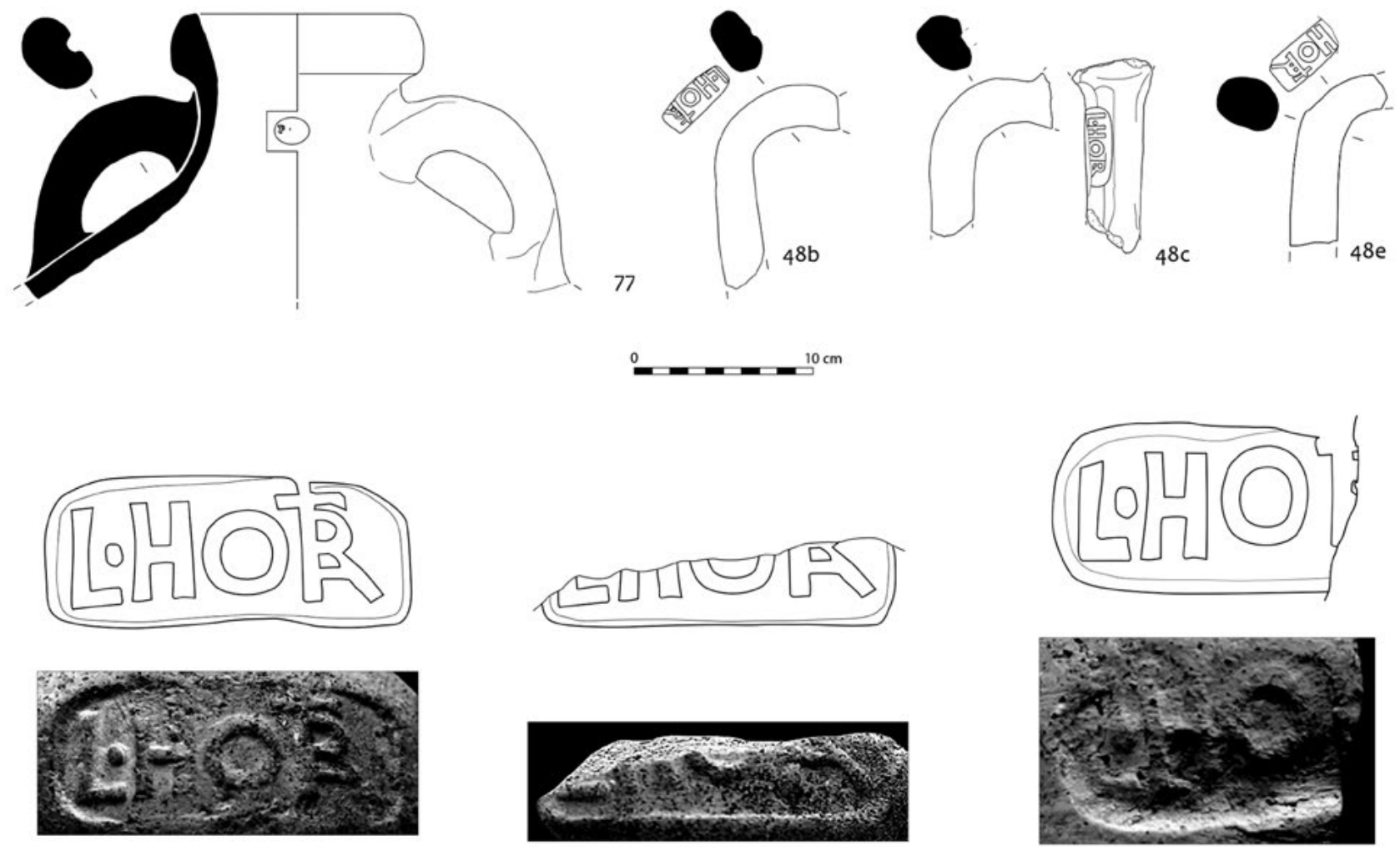

FIGURE 19. EPIGRAPHY ON OVOID AMPHORAE FROM GUADALQUIVIR VALLEY: SOME STAMPS FOUND IN WESTERN ULTERIOR/BAETICA. UPPER PART OF OVOID 6 AMPHORAE WITH STAMP TE'[---] (ABOVE, LEFT); UNDETERMINED OVOID TYPE HANDLES WITH STAMP L.HORATI (ABOVE, RIGHT) AND SOME FRAGMENT DETAILS OF STAMP L.HORATI (ACCORDING TO FABIÃO ET AL. 2016). 
must have arrived at Neuss very early on in the life of the military fortress, whose beginning is dated around 16 BC. From a typological point of view, this piece could be defined as 'early Oberaden 83 ' and could be dated to before the Oberaden horizon (González Cesteros and Berni Millet 2018: 22-23).

The inscription is quite significant because at the present it comprises the first epigraphic evidence on a south Spanish olive oil amphora. This epigraphic system has nothing in common with that documented on Dressel 20 at Monte Testaccio: the colour of the ink, rubrum but not atramentum, as well as the tall and thick calligraphic style are very different from black, shorter writing style typical of the later dating Dressel 20. Unfortunately, the letters are difficult to read: just some faded remains now exist. The inscription is of two different parts: the first one placed on the neck and the second crossways on the lower part of the handle. The neck inscription seems to be the end part of a numeral, probably a small unit. The part placed on the handle may be in two possible lines and seems to be a personal name, a duo or trianomina divided by dots. It may be that the person of this name was the officer in charge of the control of filling the amphora with oil in Baetica and, in that case, we would possess the earliest example of tituli picti to do with the organisation of the olive oil trade delivered from South Spain.

If so, this places the beginning of the controlled olive oil importation from south Hispania already by the two last decades BC. But, as already mentioned, the system then seems to be completely different to the one used later on, from the 1st century AD.

\section{Production places}

In our paper published in 2011, we dedicated a section to the production places of the Guadalquivir ovoid amphorae, titled 'Production contexts: advances in the (lack of) knowledge', ${ }^{18}$ clearly indicating the almost complete absence of any data about the workshops where these amphorae were produced. This is still one of the problems of the research into these amphorae. It is not a minor issue, since most of the confirmation archaeologists have about amphora manufacturing locales comes from the excavation of kiln sites and their associated wasters. There are some places where amphora production is known to have taken place, but where not a single workshop has been discovered: one such case is the important production occurring at Ephesus, but here at least there are plenty of examples of well-defined amphorae forms and a long series of archaeometrical analyses has been done (Bezezcky 2013: 25-31). We must admit that the problem is more acute when amphorae types are in the process of evolving in their morphology

${ }^{18}$ The original Spanish title was: Los Contextos de Producción: avances en el (des)conocimiento (García Vargas, Almeida and González Cesteros 2011: 253). towards a standardised form and for a product being exported en mass.

Nevertheless, we can say the situation is slowly being transformed, step by step. If we compare the data we have now with that available in 2004, that is not a single documented workshop (Chic García and García Vargas 2004: 307), or in 2011, that is some data was known about the so-called 'urban workshops' of Carmo/ Carmona and Ilipa Magna/Alcalá del Río (García Vargas, Almeida and González Cesteros 2011: 254; García Vargas 2012; González Cesteros, García Vargas and Almeida 2018), then the current situation reveals new possible or certain production places of Ovoid amphorae all along the Guadalquivir and Genil valleys, and opens new scope for future research.

\subsection{Amphorae workshops in the Guadalquivir valley. An overview of the recent research}

Even if the situation is better than some years ago, there is still a big hole in our knowledge of the production places all along the Guadalquivir valley prior to the production of the first Dressel 20 in late Tiberian or early Claudian times. This situation can result from multiple factors, but two of them are probably more important. On the one hand, the dearth of documented workshops can be related to the overwhelming quantity and great physical size of the Dressel 20 amphorae workshops of the Guadalquivir and Genil valleys, whose massive output over three centuries may have masked the earliest stages of production of Roman amphorae in this area (Berni Millet 1998: 27). The other cause for our ignorance, and in our personal opinion the germane one, is related to the misidentification of most ancient amphora types and the different geographical locations of some workshops then, that were following still pre-Roman patterns (vide infra).

Studies about amphora production workshops in the Guadalquivir area have a long tradition: the first steps are to be found in the works of G. Bonsor in the last decades of the 19th century; work continued in the second part of the 20th century chiefly by M. Ponsich, but also by J. Remesal Rodríguez and G. Chic García. ${ }^{19}$ Since the last moments of the 20th and early years of the 21th centuries important advances have been made in research on the amphora workshops in our region. Even if the great majority of the workshops has never been excavated and even if we only know about their existence from the quite impressive surface remains, yet some archaeological excavations have been done in places such as El Tejarillo (Canania/Alcolea del Río), El Cortijillo (Celti/Peñaflor), Huertas de Belén (Palma del Río), Castillo de Azanaque (Lora del Río), Malpica (Palma del Río), Palmosilla Baja (Écija), Arva/Alcolea del Río, and recently in El Mohino (Palma del Río), among others. However, we feel that two

\footnotetext{
${ }^{19}$ For an accurate description, see the historiographical overview made by P. Berni Millet (2008: 203-215).
} 


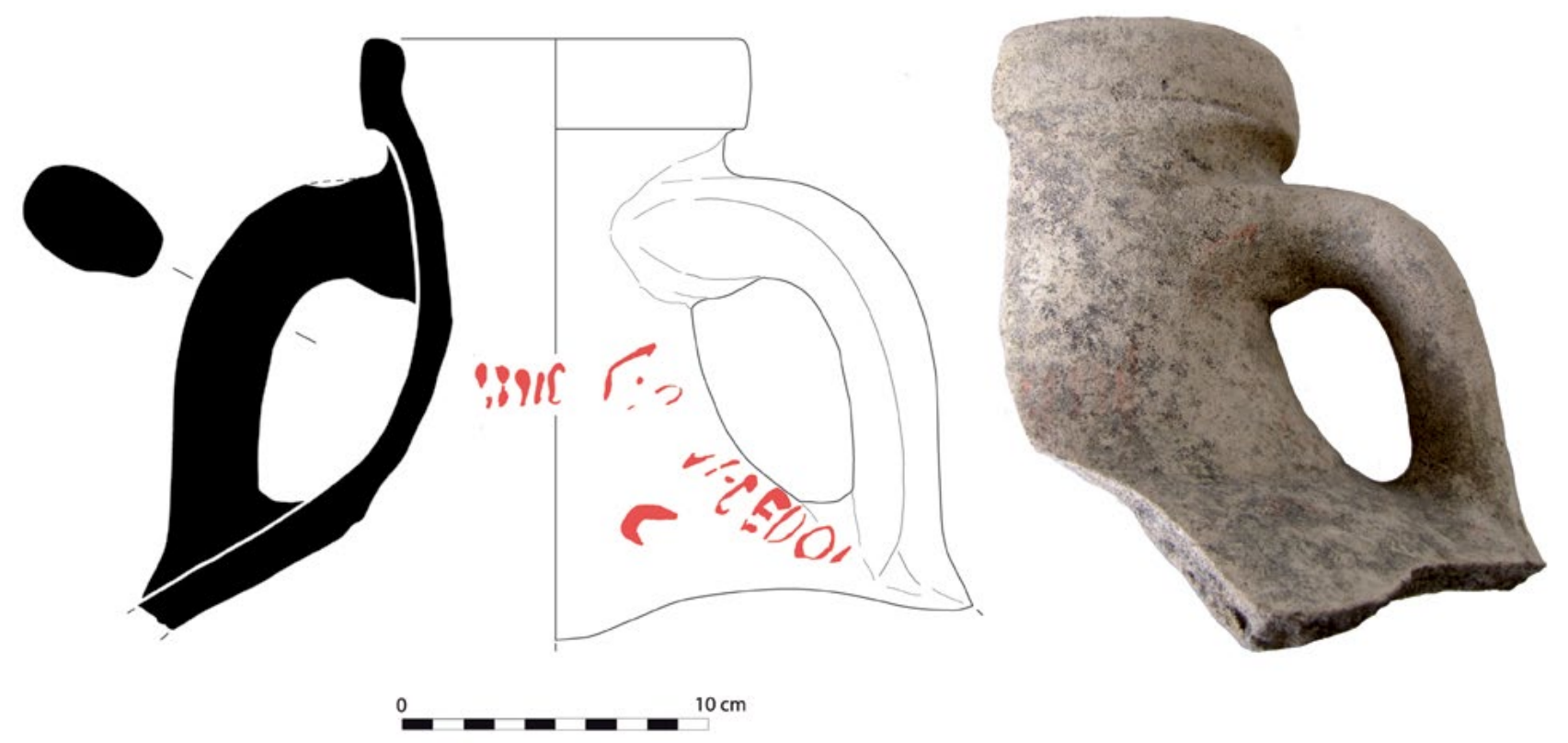

FIGURE 20. EPIGRAPHY ON OVOID AMPHORAE FROM GUADALQUIVIR VALLEY: TITULUS PICTUS FROM NEUSS.

places should be highlighted apropos the new data about the early Imperial production phase: the excavation of the important workshop of the Hospital de las Cinco Llagas or Parlamento de Andalucía, in the centre of current Seville (García Vargas 2003a, 2003b; Tabales Rodríguez 2003), and that of two different periods in the workshop of Las Delicias (Astigi/Écija) (Sáez Fernández et al. 2001; Mauné et al. 2014).

The advances in research over the last years into the amphorae production places in the Guadalquivir valley has been based in the work of individual scholars. Probably the most key one has been P. Berni Millet (2008), a worthy successor to Bonsor and Ponsich, but one must not forget others like J. Barea Bautista, S. Barea Bautista, J. Solís Siles, J. Moros Díaz (2008), nor the fresh perspective introduced by the projects developed in the last years by the Montpellier University, with the assistance of the University of Seville. Unfortunately, most of the works and studies of the last years focussed on workshops have not documented ovoid forms, but some new data exists that we should now carefully analyse.

\subsection{Current data about the Republican and Augustan amphorae production in the Guadalquivir valley}

Several finds made in the last years have to a degree contributed to forge new approaches concerning the production of the ovoid and related Republican and Augustan types in the region, even if much is undefined in the picture and even if we must wait for new and clearer evidence. Some of the findings now presented should not be taken as proven evidence of the amphorae production in the places involved, because they are neither numerous nor have been found in precise stratigraphical contexts. For this reason and utilizing the most up-to-date data, we have tried to distinguish between the possible and the sure production places. Unfortunately, the first group is the most numerous.

\subsubsection{Documented production places}

Today, just two sites can be classified as sure production places for Guadalquivir ovoid amphorae and related forms. These places, discovered in the last years, differ in their geographical position and the quality and nature of the available data. They lie in different segments of the Guadalquivir valley, but also they occupy different sorts of positions apropos the settlement distribution of the region in the late Republican and early Imperial times. Both are placed at some distance from the river. The first one is in the suburban area of ancient Carmo/Carmona (Seville), near the Via Augusta, the most important route of the region since pre-Roman times (Rodríguez Rodríguez 2001), while the workshop of Fuente de los Peces (Fuente Palmera, Cordoba) is not connected with any important urban settlement and is placed in the countryside (González Tobar and Mauné 2018).

The workshops found at Carmo/Carmona (Seville) have been documented due to the rescue archaeological excavations carried out in recent years in the city. These have recovered the existence of an artisan area dedicated to the manufacture of ceramics located outside the city walls, along the Via Augusta at its exit from the town by the gate now called Seville. In this area, some plots with evidence of pottery activity have been excavated: Montánchez 4 (Rodríguez Rodríguez 2001), Montánchez 15 (Gómez Saucedo 2009), Doctor Fleming 13-15 (Conlin and Ortiz forthcoming), Doctor Fleming 25 (Gil et al. 1990) and González Parejo 19A (Gómez Saucedo forthcoming). 
The earliest evidence of Roman pottery production in the sector dates back ${ }^{20}$ to the late Republican and early Augustan periods, with pottery production continuing until the Flavian period.

In the plot Doctor Fleming 13-15, the dumps of the kiln waste can be dated according to the table ceramics present (Campanian B of the forms Lamb 5/7, thin walled Mayet VIIIC and imitations of Italian type sigillata of form Conspectus 7) to around 30-20 BC. Pottery products include painted Turdetan basins and urns and amphorae of Pellicer D and Haltern 70 forms. The morphology of the last corresponds to the period of transition from the Ovoid 4 form to Haltern 70, dated between 30 and 20 BC (García Vargas, Almeida and González Cesteros 2011), a time that coincides with the date provided by the fine wares of these rubbish layers.

Of Augustan or already Tiberian date are the layers filling the abandoned kilns of plot González Parejo 19A (Italian terra sigillata with an ATEI stamp in planta pedis, thin walled forms Mayet 9A, 24A and 35) in which is documented the presence of an amphora Ovoid 4 and another one of the Type 10 of the Guadalquivir, both in a context dominated by both the plain ceramics and the painted ones of Turdetan tradition.

The same painted Turdetan repertoire is documented in the filling layers of the kilns of the first phase at Doctor Fleming 25 (Gil et al. 1990). These also contained socalled 'lucernas-cuenco' ('bowl-lamps'), of an indigenous tradition (Ferrer Albelda and García Fernández 2008: 208, Escacena type VI): they begin in the 4 th century and must reach the last decades of the 1st century $B C$, as can be deduced from their presence also in the dump of the plot Doctor Fleming 13-15. This horizon of Doctor Fleming 25, dominated by the final Turdetan productions, includes two fragments of an amphora of the Ovoid 6 type which, although they are not firing failures, are of a purified calcareous and cream-coloured fabric so characteristic of Carmona's productions, and can therefore be classified without much doubt as local productions.

In spite the fact that the pottery workshop of Doctor Fleming 25 was excavated without following a stratigraphical procedure, we believe that this late Republican 'horizon', including Ovoid 6 amphorae and ceramic types of Turdetan tradition, is clearly prior to the repertoire of bowls, basins, jars, lids and mortars which constitute the bulk of everyday pottery productions and can be dated from the late Julian-Claudian or more probably Flavian period. This date can be assigned to them from the morphology of the common wares (especially jugs and pots), particularly from the peculiar shape of some bowls of the Hispanic thin-wall ceramic repertoire that are morphologically close to the Mayet

\footnotetext{
${ }^{20}$ Further north, in the Plazuela de Lasso were detected and excavated evidence of pre-Roman pottery.
}

type 37 and also from a rim fragment of a Drag 27 type in South Gaulish terra sigillata.

From the contexts excavated in the plots of Doctor Fleming 13-15 and 25 of Carmona and in the 19A of González Parejo, which are all physically very close to each other, we can deduce the existence of first a late-Republican horizon in the pottery production of Carmona turning out Ovoid 4 and Ovoid 6 amphorae and of Type 10 of the Guadalquivir repertoire around the mid-1st century BC, and then immediately after in around the 30-20s types Pellicer D and Haltern 70. The workshop(s) were not dedicated exclusively to the manufacture of amphorae, but also manufactured common and painted wares, most of them within the local pre-Roman tradition.

A later floruit of these Camona production centres would be represented first by the common wares (already fully Romanised) of a fourth workshop, the one represented by the material from plot Montánchez 15 and of the JulioClaudian period, and secondly by the common wares and Haltern 70 amphorae (1st century $\mathrm{AD}$ ) of the second phase of the workshop of Doctor Fleming 25, also from the final Julio-Claudian period or into the Flavian.

Different again is the situation related to some recent finds made in the Oleastro project in the Baetican countryside. Without any doubt, one of the most important discoveries concerning amphorae production centres in the Guadalquivir valley has been made by I. González Tobar (González Tobar and Mauné 2018) at the site called 'Fuente de los Peces' (Fuente Palmera, Cordoba). Thanks to the intensive field work, a high number of Augustan-Tiberian amphorae fragments associated with the stamps MR and T.A.M. ${ }^{21}$ has been documented. Though systematic excavation at Fuente los Peces is yet to happen, the production there of Ovoid 7 (Oberaden 83) and Haltern 71 - based on the typology of rims and upper parts fragments, as well as of Dressel 20 systematically associated with the T.A.M. stamp is attested. Future excavation in this place will be guaranteed to greatly increase the volume of information about amphorae production in the late 1st century $\mathrm{BC}$ and early 1 st century AD.22

\footnotetext{
${ }^{21}$ The first one is the well-known MR stamp found in several places along the German border and quite possibly in Ostia. It is one of the earliest stamps on olive oil amphorae after the Horatius group, most probably on Ovoid 7 (Oberaden 83). It normally appears on rims and has some variants (González Tobar and Mauné 2018). Its presence in Haltern gives an accurate chronological framework for the beginning of this product (González Cesteros 2014). Concerning the exemplar from La Longarina mentioned by R. Etiénne and F. Mayet (2004: 66), on a Haltern 71 rim fragment already published by A. Hesnard (1980), no clear documentation exists in the original publication, but one can accept the account of the French scholars because the publication of Hesnard was but a preliminary review of the important Augustan depot.

${ }^{22}$ We visited Fuente los Peces in December 2018 together with I. González Tobar, whom we thank for his kindness and the interesting conversations. On the ground surface, we found many rim fragments on Haltern 71 with the MR stamp, alongside the rims and upper parts of Ovoid 7 (Oberaden 83).
} 
Finally, one should add that Haltern 71, dated around the first decade of the 1st century AD, are also noted among the products of Phase 1A of the pottery from El Mohíno (Palma del Río, Córdoba), where they were produced together with Haltern 70 (González Tobar et al. 2019).

\subsubsection{Possible production places}

Apart from the two sites mentioned above as workshops certainly producing ovoid amphorae, another, if only possible, production centre for Republican and, above all, Augustan ovoid amphorae should be located in the urban or suburban area of Ilipa Magna/Alcalá del Río (Seville). A monumental complex of the 1st century AD was built over the dump of a pottery workshop that contained some overfired ceramic fragments and the walls of a kilnsite (García Vargas 2012). Among this material, fragments of several amphora types were found, most of them belonging to Haltern 70, Dressel 20 and Dressel 28, but also to Haltern 71 .

Supplementary observations about production areas have also been provided by J. Moros Díaz and P. Berni Millet, based on the finding of rim fragments in different archaeological sites:

- An Ovoid 1 rim fragment found on the groundsurface in the well-known Dressel 20 workshop of Huertas del Río (Lora del Río, Seville). This casual find at a workshop whose production is dated from the Flavian dynasty until the reign of Antoninus Pius (Berni Millet 2008: 359) suggests an earlier date for the site, or maybe the existence of a different and earlier workshop nearby. As it is just a single fragment and moreover found on surface, we cannot confirm that this piece was produced there, even if it seems quite possible.

- A similar case is other Ovoid 1 rim fragment found again on surface by J. Moros in the very important production place of Dressel 20 at La Catria, on the river bank opposite Huertas del Río (cf. Figure 21). Based on the stamp evidence, the earliest stages of this workshop are to be dated to the mid1st century AD (Berni Millet 2008: 320), but this discovery could again indicate the existence of a workshop of an earlier date somewhere nearby.

Although these rim fragments found on the surface cannot confirm the production of ovoid forms in those two workshops, it does look quite possible that production at some level existed already before the emergence of the huge workshops that produced mainly Dressel 20.

Upriver, in the Andalusian province of Cordoba, a pair of other possible workshops with production of ovoid types also has ben also recently suggested:

- the first is the one called 'El Bombo' (Fuente Palmera, Cordoba), where was documented a rim of an Ovoid 5 (González Tobar and Berni Millet 2018). It is suggested that this place might be a workshop producing ovoid amphorae and Haltern 71 , in a similar way as did the workshop of Fuente de los Peces.

- the second is the site of 'Carneriles 1' (Fuente Palmera, Cordoba), where some fragments of Ovoid 7 (Oberaden 83) and Haltern 71 have been found on the surface (González Tobar and Berni Millet 2018).

Both places are really quite close to the Haltern 71 production place of Fuente de los Peces that has provided more accurate information about the amphorae production in Augustan times (cf. González Tobar and Mauné 2018).

Taking these observations of the last paragraphs into account, we can now argue that in the last years a tiny increase in the documented production places for the different types of Guadalquivir ovoid amphorae has occurred. However, it is with the production of the form Haltern 71, a non-ovoid type and a late Augustan and Tiberian olive oil vessel, that the greatest progress has happened.

Based on the studied material from the Augustan and Julio-Claudian Roman settlements in the lower Rhineland (González Cesteros 2014), we may confirm the transformation of the olive oil containers around the BC/AD pivotal point (González Cesteros 2014; González Cesteros and Tremmel 2015; González Cesteros and Almeida 2017), something that had already been proposed by other scholars such as P. Berni Millet (1998, 2008) or R. Étienne and F. Mayet (2000).

Some remarks must be made here concerning the Haltern 71 amphorae that are of great relevance for a better understanding of their production in big rural workshops in the Guadalquivir valley. Even if they continued the development in form and economic process started by the Ovoid 6 and Ovoid 7 (Oberaden 83) types, and even though they differ from the Dressel 20 in basic aspects as to the shape, yet their epigraphic habits, their massive level of production and their presence in one of the most important markets for the Baetican olive oil all help us to separate their story from that of the previous ovoid amphorae. The percentage of Haltern 71 in the German settlements dated after the $\mathrm{BC} / \mathrm{AD}$ point is altogether greater than their 1st century $B C$ forerunners achieved, with the Haltern 71 becoming virtually the only olive oil container documented in this region. ${ }^{23}$ This situation confirms the capture of the northern market by

\footnotetext{
${ }^{23}$ Even if the Ovoid 7 (Oberaden 83) is quite dominant within the olive oil amphorae before the Haltern chronological horizon, still there is room for other amphorae imports, mainly from Apulia and Istria (cf. contributions of H. González Cesteros and D. Tretola Martínez in this volume). In Haltern, we have documented also some amphorae sherds that must be classified as Dressel 24, an Aegean amphora associated with olive oil too (personal observation of H. González Cesteros).
} 


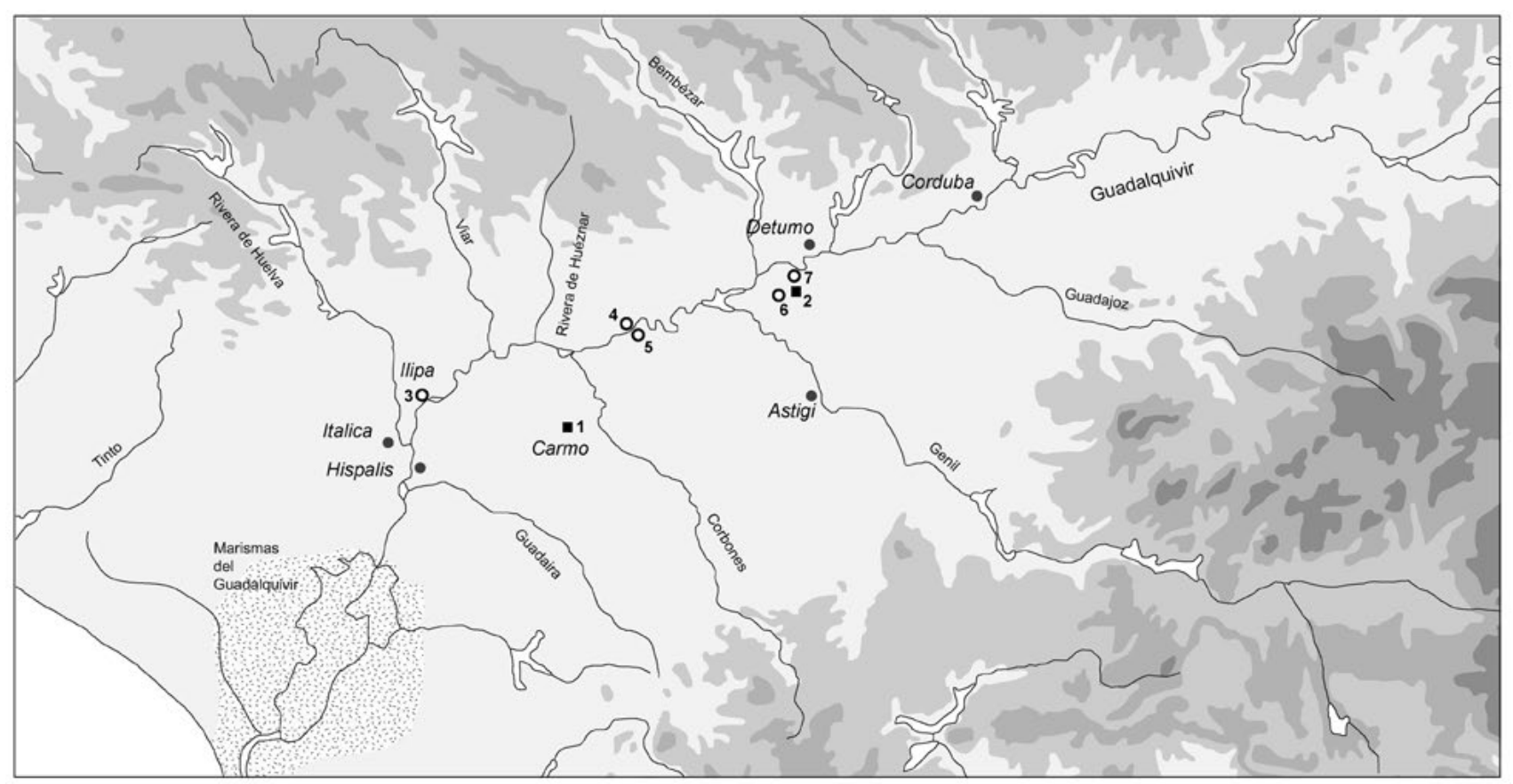

Figure 21. MAP of CERTAin AND POSSIBLE PRODUCTION CENTRES. DOCUMENTED PRODUCTION CENTRES: 1. CARMONA; 2.

Fuente de los Peces (Fuente Palmera, Cordoba). Possible production centres: 3. Ilipa Magna (Alcalá del Río, Seville); 4. Huertas del Río (Lora del Río, Seville); 5. La Catria (Lora del Río, Seville); 6. El Bombo (Fuente Palmera, Cordoba); 7. Carneriles 1 (Fuente Palmera, Cordoba).

Guadalquivir olive oil in late Augustan times, something that can also be observed from the physical attributes of these vessels. Although the Ovoid 7 (Oberaden 83) already did present a high degree of standardisation, we can still find some lack of homogeneity in parts such as necks and bodies, or in the way the different parts of the vessel make up the complete amphora. However, and even though some authors argue for differentiation within the Haltern 71 (suggesting a division to create Haltern $71 \mathrm{~A}$ and B: Berni Millet forthcoming), the variation in form within the Haltern 71 seems to be more in the way of a step in its development towards the final shape of the first Dressel 20 , rather than being owed to any variation of shape and capacity due to their production in different workshops or by different potters. If we compare them all (García Vargas, Almeida and González Cesteros 2011: Figures 22$23 / 25 / 26$ ), we can clearly see the high standardisation in form the Haltern 71 achieved in comparison with the Ovoid 6 and Ovoid 7 (Oberaden 83).

We have yet to accommodate the amphorae production in the figlinae in relation to these formal and economic transformations/developments. From this moment onwards, the production of olive oil amphorae reached an altogether new level in the Guadalquivir valley. We can surmise that a mass production was introduced with a concomitant enlargement of the production centres, including the creation of new ones, during the lifetime of the Haltern 71 , that is to say roughly 0-30 $\mathrm{AD}$ (vide supra). The finds of some ovoid and Turdetan amphorae fragments in pottery workshops (or in the vicinity of the same) where later types are documented seems to confirm
P. Berni's hypothesis about the early workshops (at least the pre-Haltern 71 production places) being covered by the ones producing Dressel 20 amphorae. Regarding this, it is important to keep in mind that the early workshops producing ovoid forms could simply have been adapted and expanded to cater for the new massive and regulated production.

In our opinion, in the continuous development of the Guadalquivir valley amphorae from the ovoid types to the early Imperial vessels, there were not, in most cases, abrupt changes, but rather a continuous development and adaptation to the Roman economy and State needs. It does not mean that all the Baetican Imperial containers began in the second half of the 1st century $\mathrm{BC}$ (as is still accepted by some scholars). Though it is clear that the production structures, the political organisation, the cultural background, and also the shape of the vessels was quite different then from later times. The transformation happened continuously and for over half a century (in case of the olive oil containers almost hundred years was required), until there were achieved new and consolidated forms that from that moment on changed but slightly.

\section{Transforming the Roman economy. The contribution of the Ovoid amphorae to the economy of the Roman Empire}

The development from the ovoid types of the 1st century $\mathrm{BC}$ to the Imperial forms must be understand as a constant but very complicated and multifaceted process, 




Ovoid 1

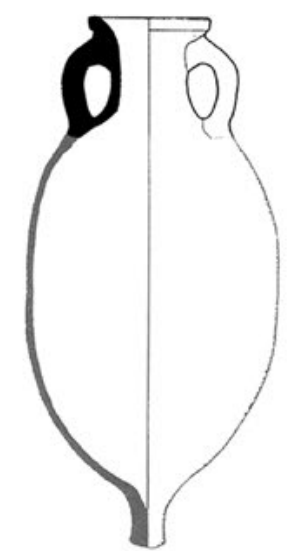

Ovoid 2

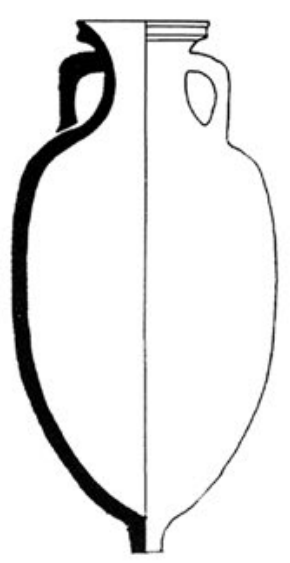

Ovoid 3

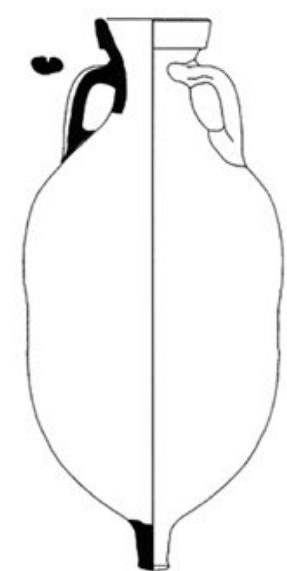

Ovoid 4

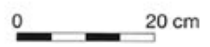


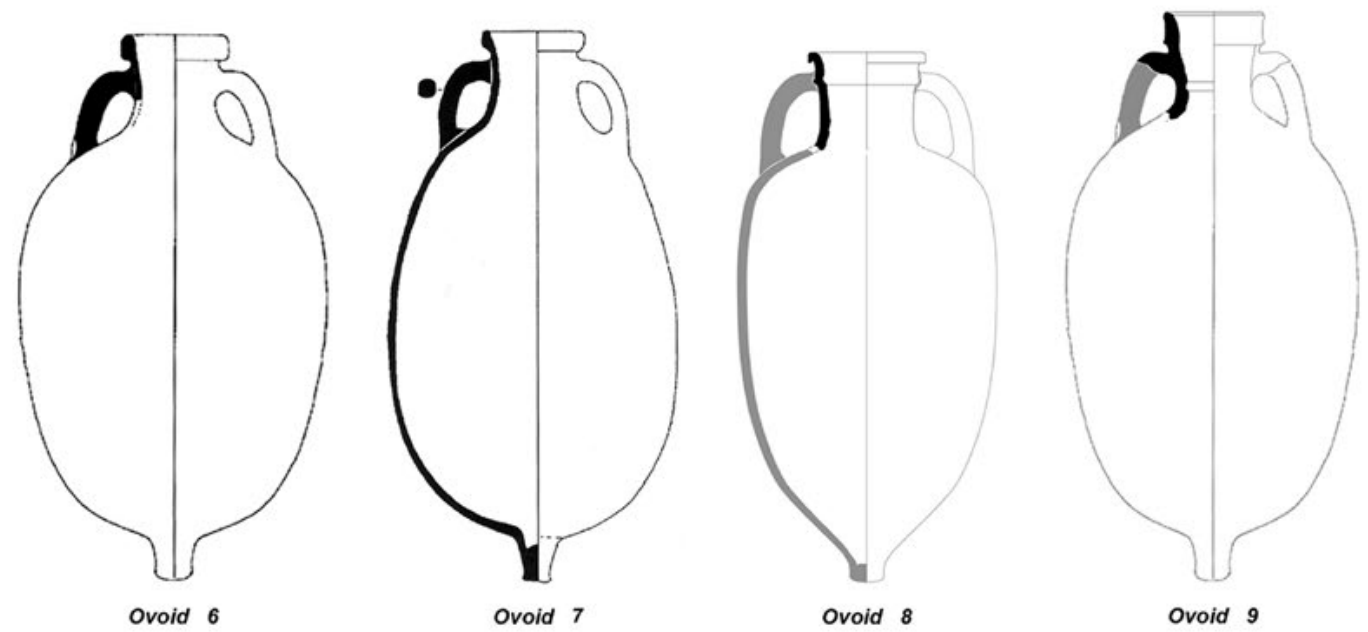

FIgURE 22. OVOID AMPHORAE TYPES PRODUCED IN THE GUADALQUIVIR VALLEY DURING THE 1ST CENTURY BC.

as an adaptation to the extremely rapid changes that shook the Mediterranean economy and politics during the late Republican and early Imperial times.

In this complex process, the territories of Hispania Ulterior/Baetica played a very important role. In case of the Guadalquivir valley, emphasis was put on the mass production of its more important agrarian commodities, that is wine or wine by-products, and above all olive oil. In the first half of the 1st century $\mathrm{BC}$, there emerge the first containers for the expediting of these products, and probably for other commodities as well. At first, the forms of the vessels were based on parallels that came from other important production regions in the Mediterranean, in particular those from the south Italic territories. The process of copying took place in a relatively short time in the Guadalquivir valley, and already by the mid decades of the 1st century BC its own amphora repertoire had started to be produced. As we have seen in the first pages of this article, the search for an identity of its own expressed in a Romanizing style during the 1st century $\mathrm{BC}$ led to the creation of a great variety of amphora types, some of them produced for but a short while and/or in just a specific area of the valley. It is only from the mid-decades of the century that the family of the early Roman amphorae of the Guadalquivir contracts and concentrates on what become the most important forms that made an impact on the supraregional markets, as the archaeological evidence clearly indicates (García Vargas, Almeida and González Cesteros 2011: 211-235).

The Augustan Principate was a very important period for the configuration of the western provinces of the Roman Empire and at that moment the most important markets for the Baetican products came into being. After the conquest of the Gaulish territories, Augustus paid special attention to enlarging the Roman territories in Northwest Europe, establishing as a priority a military zone around the Rhineland in preparation for the conquest of the territories on the other side of the river. It was his intent to pursue the aggrandizement of the Roman State in a programme of universal conquest, that being the destiny of Rome (González Cesteros 2014). The development of a very active military area of soldiers originally from 
the Mediterranean region posed a logistical challenge for the Roman administration - to supply from scratch a very important body of people ${ }^{24}$ with the fundamental produce for the Roman way of life and diet, such as salt, olive oil and wine that were not easy to find so far north. Alongside the military needs, the other important demand on the Hispanic commodities was made by the city of Rome, continuously growing from the late 2nd century BC. Despite the near permanent civil wars that convulsed the 1st century BC, the urban population of the capital increased unceasingly, so becoming the biggest metropolis ever known. The reasons behind this spectacular rise are to be sought in the production system based on slave labour (Carandini 1981) and the arrival of huge quantities of Italian peasants to be absorbed into the urban plebs.

The establishment of these two massive markets and their explosion in the Augustan period afforded the western regions a great economic opportunity, placing Baetica in a privileged position, as the amphorae evidence confirms. The role played by the Roman state in increasing the level of the Baetican agrarian products seems to have been essential for the development of the province as one of the biggest suppliers of basic commodities throughout the early Imperial times, with the process already under way in the central quarters of the 1st century BC, as the production and exportation of ovoid amphorae suggest.

During the last two decades of the 1st century $\mathrm{BC}$ and into the 1st century $\mathrm{AD}$, the products from the Baetican seas and fields literarily flooded the military camps at the Rhine and the city of Rome; further, they extended their commercial ambit to other regions such as the Adriatic, the military frontier at the Danube, and even the Eastern Mediterranean, even if here they never reached the same quantities as they enjoyed in the western part of the Empire. The extraordinary diffusion of the Baetican amphorae led to their imitation in other places, such as Lusitania, Tarraconensis, including the island of Ibiza, Galia Narbonensis and Galia Lugdunensis, among others. The imitations of Baetican amphorae of the early Imperial period targeted the same markets the genuine Baetican products had captured: the fact is clearly an indirect indication of the huge circulation achieved by the Baetican olive oil, fish products and other commodities.

By the mid of the 1st century $\mathrm{AD}$, the amphora production in the Guadalquivir had already attained a new, highly standardised and well-ordered process, based on the production and exportation of olive oil, almost as a monopolistic. The megalopolis of Rome had a well-organised distribution and supply system that demanded olive oil in massive quantities. Further, the well-established military frontier in the North did not move nor was it really threatened for a long period. The setting-up and refinement of the supply system for both, the city of Rome and the army, and the prevailing longterm peace combined to ensure a full-scale activation and in some cases the mass-production of agrarian commodities in other western provinces, situated much closer to the main customers and consumers. Thus, the Gaulish provinces provided wine to the military frontier from probably the earliest moments (Marlière 2002; González Cesteros 2014, 2015; González Cesteros and Berni Millet 2018), and later made their big move, expanding into the Mediterranean markets, with Rome being one of the most important goals.

Nevertheless, until the rise of the African production from the end of the 2nd century $\mathrm{AD}$, the olive oil carried to Rome and to the Rhine frontier would mainly be that from the Guadalquivir valley, transported in globular containers. The initial phases were in fact conducted by the extended 'family' of the ovoid amphorae, produced and exported even before Hispania Ulterior changed its name and became transformed to Roman Baetica.

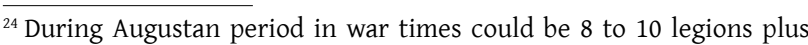
auxiliary troops acting in the Rhine frontier.
} 
FiguRE 23. GENERAL DISTRIBUTION OF THE GUADALQUIVIR VALLEY OVOID TYPES (According to García VARgas, Almeida and GonzÁlez Cesteros 2011).

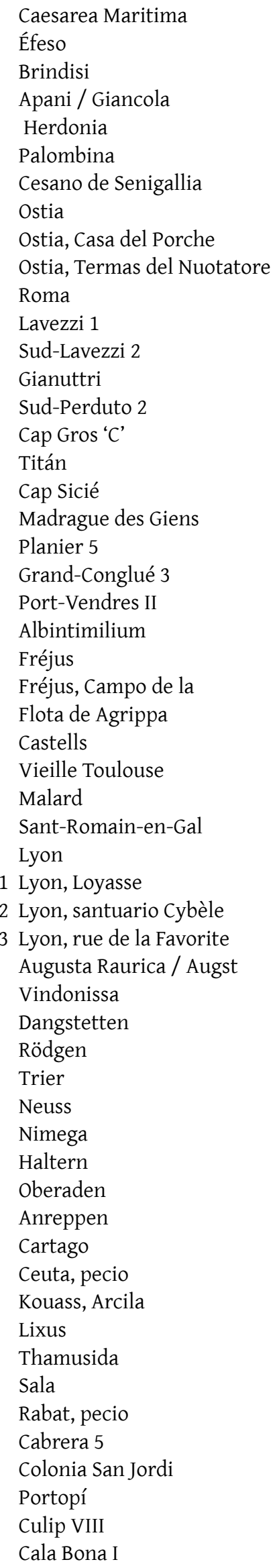

\begin{tabular}{|c|c|c|c|}
\hline 50 & Ampurias & & Castillo de Doña Blanca \\
\hline 50.1 & Ampurias, Cardo D & 87.2 & Puerto de Santa Maria, C/ Javier \\
\hline 51 & Illes Formigues I & & de Burgos \\
\hline 52 & Iluro & 87.3 & Puerto de Santa Maria, Jardin del \\
\hline 53 & Mataró & & Cano \\
\hline 54 & Badalona, Baetulo & 88 & Jerez de la Frontera \\
\hline 55 & Santa Perpétua de Mogoda, & 88.1 & Jerez de la Frontera, C/ Troilo \\
\hline & Vallès & 88.2 & Jerez de la Frontera, Rabatún \\
\hline 56 & El Villarenc & 89 & Rancho Centeno \\
\hline 57 & Tarragona, Tarraco & 90 & Cerro Overo \\
\hline 58 & castellum de Puigpelat, Alt Camp & 91 & Dos Hermanas, Orippo \\
\hline 59 & Celsa & 92 & Coria, Cauria \\
\hline 60 & Benicarló, pecio & 93 & Osset, San Juan de Aznalfarache \\
\hline 61 & Valencia, Valentia & 94 & Cerro de la Cabeza, Laelia \\
\hline 61.1 & Valencia, Plaza de la Reina & 95 & Sevilla, Hispalis \\
\hline 61.2 & Valencia, Corts Valencianes & 95.1 & Sevilla, Calle Alemanes 25 \\
\hline 62 & Valeria & 95.2 & Sevilla, Palacio Arzobispal \\
\hline 63 & Ercavica & 95.3 & Sevilla, Patio de Banderas del \\
\hline 64 & Segobriga & & Alcázar \\
\hline 64.1 & Segobriga, Rasero de Luján & 96 & Santiponce, Italica \\
\hline 65 & Pozo Sevilla & 97 & Alcalá del Rio, Ilipa Magna \\
\hline 66 & Denia & 97 & Ilipa \\
\hline 67 & Punta del Arenal (Duanes) & 98 & Carmona, Carmo \\
\hline 68 & Lucentum & 98.1 & Carmona, Albollón \\
\hline 69 & El Monastil (Elda) & 98.2 & Carmona, C/ Doctor Fleming \\
\hline 70 & Portus Ilicitanus & 98.3 & Carmona, C/ González Parejo \\
\hline 71 & Ilici & 98.4 & Carmona, C/ Montánchez \\
\hline 72 & San Ferreol & 99 & Munigua \\
\hline 73 & Cartagena, Carthago Nova & 100 & Écija, Astigi \\
\hline 74 & El Molinete (Cartagena) & 101 & Posadas, Detumo \\
\hline 75 & Loma de Herrerías (Mazarrón) & 101 & 1 Posadas, Dehesa de Arriba \\
\hline 76 & Cueva de las Peñas Blancas & 102 & Córdoba, Corduba \\
\hline 77 & Cerro del Mar & 103 & La Loba \\
\hline 78 & Málaga, C/ Carreteria & 104 & Tejada la Nueva, Ituci \\
\hline 79 & Guadiaro, Barbesula & 105 & Cerro del Moro \\
\hline 80 & El Rinconcillo & 106 & El Castillejo \\
\hline 81 & Baelo Claudia & 107 & Huelva, Onuba \\
\hline 82 & Ensenada de Bolonia & 108 & Castro Marim \\
\hline 83 & Vejer de la Frontera, & 109 & Cerro do Cavaco, Tavira \\
\hline & Convento de las Concepcionistas & 110 & Faro \\
\hline 84 & San Fernando & 111 & Monte Molião \\
\hline 84.1 & San Fernando, Campo Soto & 112 & Mesas do Castelinho \\
\hline 84.2 & San Fernando, & 113 & Mértola, Myrtilis \\
\hline & Cerro de Los Mártires & 114 & Castelo da Lousa \\
\hline 84.3 & San Fernando, Gallineras & 115 & Quinta do Almaraz \\
\hline 84.4 & San Fernando, La Milagrosa & 116 & Lisboa, Olisipo \\
\hline 85 & Cádiz & 117 & Santarém, Scallabis \\
\hline 85.1 & Cádiz, c/ Gregorio Marañón & 118 & Alto dos Cacos \\
\hline 85.2 & Cádiz, Casa del Obispo & 119 & Chões de Alpompé, Moron? \\
\hline 85.3 & Cádiz, La Caleta & 120 & Lomba do Canho \\
\hline 85.4 & Cádiz, Plaza San Antonio & 121 & Porto, Aljube \\
\hline 85.5 & Cádiz, Avenida de Portugal & 122 & Braga \\
\hline 86 & Puerto Real & 123 & Castro Santa Trega \\
\hline 86.1 & Puerto Real, Cerro de Ceuta & 124 & Castro de Vigo \\
\hline 87 & Puerto de Santa Maria & 125 & Castro de Montealegre \\
\hline
\end{tabular}

50 Ampurias

50.1 Ampurias, Cardo

51 Illes Formigues I

52 Iluro

53 Mataró

54 Badalona, Baetulo

Santa Perpétua de Mogoda

59 Celsa

61.1 Valencia, Plaza de la Reina

62 Valeria

63 Ercavica

64 Segobriga

65 Pozo Sevilla

66 Denia

67 Punta del Arenal (Duanes)

68 Lucentum

69 El Monastil (Elda)

70 Portus Ilicitanus

73 Cartagena, Carthago Nova

74 El Molinete (Cartagena)

75 Loma de Herrerías (Mazarrón)

76 Cueva de las Peñas Blancas

77 Cerro del Mar

78 Málaga, C/ Carreteria

79 Guadiaro, Barbesula

80 El Rinconcillo

81 Baelo Claudia

82 Ensenada de Bolonia

Vejer de la Frontera

San Fernando

84.1 San Fernando, Campo Soto Cerro de Los Mártires

84.3 San Fernando, Gallineras

84.4 San Fernando, La Milagrosa

85 Cádiz

85.1 Cádiz, c/ Gregorio Marañón

85.2 Cádiz, Casa del Obispo

86.1 Puerto Real, Cerro de Ceuta

87.1 Puerto de Santa Maria,
Castillo de Doña Blanca

Puerto de Santa Maria, C/ Javier Cano

88.2 Jerez de la Frontera, Rabatún

Rancho Centeno

Coria, Cauria

94 Cerro de la Cabeza, Laelia

5.2 Sevilla, Palacio Arzobispal

Alcázar

97 Alcalá del Rio, Ilipa Magna

97 Ilipa

98 Carmona, Carmo

98.2 Carmona, C/ Doctor Fleming

98.3 Carmona, C/ González Parejo

99 Munigua

100 Écija, Astigi

101 Posadas, Detumo

102 Córdoba, Corduba

103 La Loba

105 Cerro del Moro

109 Cerro do Cavaco, Tavira

111 Monte Molião

112 Mesas do Castelinho

115 Quinta do Almaraz

116 Lisboa, Olisipo

118 Alto dos Cacos

119 Chões de Alpompé, Moron?

120 Lomba do Canho

Porto, Aljube

123 Castro Santa Trega

25 Castro de Montealegre 

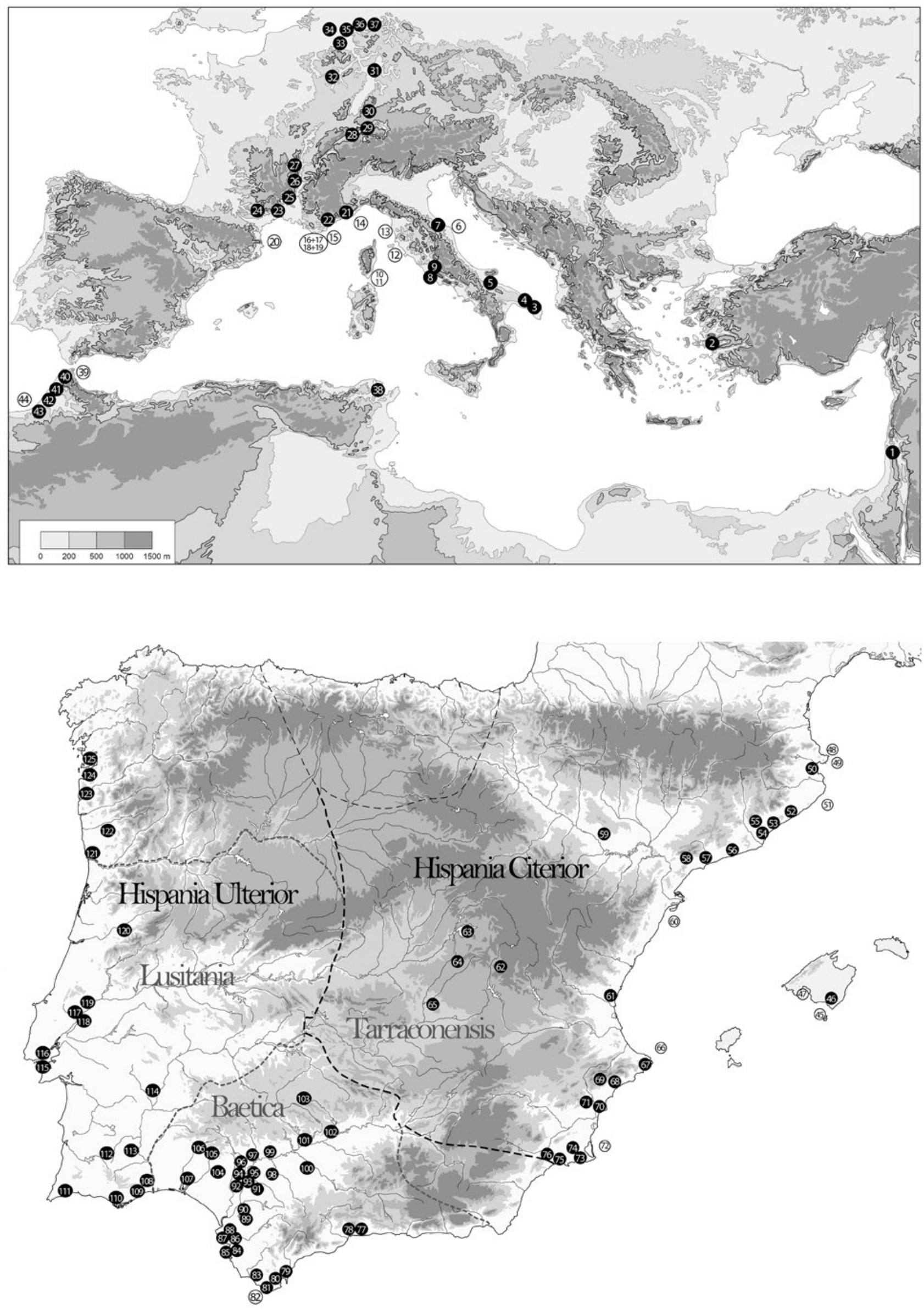


\section{Bibliography}

Aguilera Martín, A. 2004a. El producte envasat. El contenido de las Haltern 70 según los tituli picti, in Culip VIII i les Àmfores Haltern 70 (Monografies del Casc 5):119-120. Girona: Museu d'Arqueologia de Catalunya / Centre d'Arqueologia Subaquàtica de Catalunya.

Aguilera Martín, A. 2004b. El producte envasat. Defrutum, sapa y caroenum. Tres nombres y un producto: arrope, in, Culip VIII $i$ les Àmfores Haltern 70 (Monografies del Casc 5): 120-132. Girona: Museu d'Arqueologia de Catalunya / Centre d'Arqueologia Subaquàtica de Catalunya.

Almeida, R.R. de 2008. Las Ánforas del Gualdalquivir en Scallabis (Santarém, Portugal). Aportación al Conocimiento de Los Tipos Minoritarios (Col.leció Instrumenta 28). Barcelona: Publicacions i Edicions Universitat de Barcelona.

Almeida, R.R. de 2010. The incorporation of the Baetican Hinterland into the Western supply during the Late Republic. A reading based on the distribution of the Guadalquivir's minority amphora types, in C. Carreras Monfort and R. Morais (eds) The Western Roman Atlantic Façade. A study of the economy and trade in the Mar Exterior from the Republic to the Principat (British Archaeological Reports, International Series 2162): 191-196. Oxford: Archaeopress.

Almeida, R.R. de, García Vargas, E. and González Cesteros, H. 2016. Dressel 1 (Valle del Guadalquivir), in Amphorae ex Hispania. Paisajes de producción y de consumo, viewed july 2017, <http://amphorae.icac.cat/amphora/ dressel-1-guadalquivir-valley>

Almeida, R.R. de and Pimenta, J. 2018. Ânforas do acampamento / sítio romano de Alto dos Cacos (Almeirim, Portugal). Onoba 6: 3-56.

Anteas, J.M.F. 1993. Les fouilles de Malard à Narbonne. Résultats préliminaires d'un sondage sur un lit d'amphores du 1er Siécle aprés J.-C. Cahiers D’Archéologie Subaquatique XI: 67-79.

Aquilué Abadías, X., Castanyer i Masoliver, P., Santos, M. and Tremoleda i Trilla, J. 2004. Geografia del Consum de les Haltern 70. Les Àmfores Haltern 70 d'Empúries, in Culip VIII $i$ les Àmfores Haltern 70 (Monografies del Casc 5): 112-117. Girona: Museu d'Arqueologia de Catalunya / Centre d'Arqueologia Subaquàtica de Catalunya.

Aquilué Abadías, X., Castanyer i Masoliver, P., Santos, M. and Tremoleda i Trilla, J. 2008. L'evolució dels contextos ceràmics d'Empúries entre els segles II a. C. i VII d.C., in SFECAG Actes du congrès de l'Escala-Empúries. Les productions céramiques en Hispanie Tarraconaise (IIe siècle avant J.-C-VIe siècle après J.-C) (l'Escala-Empúries, 1-4 mai 2008): 33-62. SFECAG : Marseille.

Aranegui Gascó, C. (ed.) 2001. Lixus. Colonia fenicia y ciudad púnico-mauritana. Anotaciones sobre su ocupación medieval (Sagvntvm Extra 4). Valencia: Universidad de Valencia.

Arruda, A.M. 1996. O Castelo de Castro Marim, in De Ulisses a Viriato, O Primeiro Milénio a.C. (Catálogo da
Exposição): 95-100. Lisboa: Instituto Português de Museus / Museu Nacional de Arqueologia.

Arruda, A.M. and Almeida, R.R. de 1998. As ânforas da Classe 32 da Alcáçova de Santarém. Conimbriga 37: 201-231.

Arruda, A.M. and Pereira, C. 2010. Fusão e produção: actividades metalúrgicas em Monte Molião (Lagos), durante a época Romano-Republicana, in Actas do $7^{\circ}$ Encontro de Arqueologia do Algarve (Silves, 22-24 Outubro 2009) (XELB-10): 695-716. Silves: Câmara Municipal de Silves.

Arruda, A.M., Viegas, C. and Bargão, P. 2005. As ânforas da Bética costeira na Alcáçova de Santarém. Revista Portuguesa de Arqueologia vol. 8, n.1: 279-297.

Arruda, A.M., Viegas, C., Bargão, P. and Pereira, R. 2006. A importação de preparados de peixe em Castro Marim: da Idade do Ferro à Época Romana, in Simpósio Internacional Produção e Comércio de Preparados Piscícolas durante a Proto-História e a Época Romana no Ocidente da Península Ibérica - Homenagem a Françoise Mayet (Setúbal, Maio 2004) (Setúbal Arqueológica 13): 153-176. Setúbal: Museu de Arqueología e Etnografía do Distrito de Setúbal.

Arteaga Matute, O. 1985. Excavaciones arqueológicas en el Cerro del Mar. Campaña de 1982. Una aportación preliminar al estudio estratigráfico de las ánforas púnicas y romanas del yacimiento. Noticiario Arqueológico Hispánico 23: 197-233.

Baldacci, P. 1972. Importazioni Cisalpine e Produzione Apula, in Recherches sur les Amphores Romaines (Collection de l'École Française de Rome 10): 7-28. Rome, École Française de Rome.

Barea Bautista, J.S., Barea Bautista, J.L., Solís Siles, J. and Moros Díaz, J. 2008. Figlina Scalensia. Un centro productor de ánforas Dressel 20 de la Bética (Col.lecció Instrumenta 27): Barcelona: Publicacions i Edicions Universitat de Barcelona.

Bargão, P. and Arruda, A.M. 2014. The Castro Marim 1 amphora type: a West Mediterranean production inspired by Carthaginian models. Carthage Studies 8: 143-160.

Barros, L. and Henriques, F. 2002. A última fase de ocupação do Almaraz, in $3^{\circ}$ Encontro Nacional de Arqueologia Urbana (Almada, 1997): 295-311. Almada, Câmara Municipal de Almada.

Benoit, F. 1956. Épaves de la cote de Provence. Typologie des Amphores. Gallia 14: 23-34.

Benquet, L. and Olmer, F. 2002. Les amphores, in J.M. Blázquez Martínez, C. Domergue and P. Sillières (eds) La Loba (Fuenteovejuna, Córdoba). La Mine et le Village Minier Antiques: 295-331. Bordeaux: Ausonius.

Bernal Casasola, D. 2007. Vinos tarraconenses más allá de las Comunas de Hércules. Primeras evidencias en la Baetica, Lusitania y Tingitana, in A. López Mullor, X. Aquilué Abadías and R. Pascual Guasch (coords) La producció i el comerç de les àmfores de la Provincia Hispania Tarraconensis. Homenatge a Ricard Pascual i Guasch (Monografies Museu d'Arqueologia de Catalunya 8): 319-352. Barcelona: Museu d'Arqueologia de Catalunya. 
Bernal Casasola, D. 2014. Nomenclatura y taxonomía de las cerámicas de imitación hispanorromanas. A modo de psicoanálisis, in F.J. García Fernández and E. García Vargas (eds) Comer a la moda. Imitaciones de vajilla de mesa en Turdetania y la Bética occidental durante la antigüead (S. VI A.C. - VI D. C.) (Col.lecció Instrumenta 46): 9-32. Barcelona: Publicacions i Edicions Universitat de Barcelona.

Bernal Casasola, D. and García Vargas, E. 2008. Ánforas de la Bética, in D. Bernal Casasola and A. Ribera I Lacomba (eds) Cerámicas hispanorromanas. Un estado de la cuestión: 661-687. Cádiz: Servicio de Publicaciones de la Universidad de Cádiz.

Bernal Casasola, D. and García Vargas, E. forhcoming. Gades como centro de consumo entre el S. II a.C. y la antigüedad tardía. Aportaciones del registro anfórico procedente de las excavaciones en la Casa del Obispo.

Bernal Casasola, D. and Jiménez-Camino Álvarez, R. 2004. El taller de El Rinconcillo en la bahía de Algeciras. El factor itálico y la economía de exportación (ss. I a.C.- I d.C.), in D. Bernal Casasola and L. Lagóstena Barrios (eds) Actas del Congreso Internacional Figlinae Baeticae. Talleres Alfareros y Producciones Cerámicas en la Bética Romana (ss. II a.C.-II d.C.) (British Archaeological Reports, International Series 1266): 589-606. Oxford : John and Erica Hedges Ltd.

Bernal Casasola, D., García Vargas, E. and Sáez Romero, A.M. 2013. Ánforas itálicas en la Hispania meridional, in G. Olcese (a cura di) Immensa aequora Workshop. Ricerche archeologiche, archeometriche e informatiche per la ricostruzione dell'economia e dei commerci nel bacino occidentale del Mediterraneo (metà IV sec. a.C. - I sec. d.C.). Atti del convegno (Roma 24-26 gennaio 2011): 351-372. Roma: Edizioni Quasar.

Berni Millet, P. (1998): Las ánforas de aceite de la Bética y su presencia en la Cataluña romana (Col.leció Instrumenta 4). Barcelona: Publicacions i Edicions Universitat de Barcelona.

Berni Millet, P. (2008): Epigrafía anfórica de la Bética. Nuevas formas de análisis (Col.lecció Instrumenta 29). Barcelona: Publicacions i Edicions Universitat de Barcelona.

Berni Millet, P. forthcoming. Las otras ánforas del Monte Testaccio, in O. Bourgeon, E. García Vargas and S. Mauné (dir.) La producción de aceite y de ánforas oleícolas en la Cuenca del Guadalquivir en época romana. Mesa redonda (Madrid, 29-30 de octubre de 2015).

Berni Millet, P. and Miró i Canals, J. 2013. Dinámica socioeconómica en la Tarraconense Oriental a finales de la República y comienzos del Imperio. El comercio del vino a través de la epigrafía anfórica, in J. López Vilar (ed.) Tarraco Biennal. Actes del 1er Congrès Internacional d'Arqueologia i Mon Antic (Tarragona, 29-30 novembre - 1 desembre 2012): 63-83. Tarragona: Mutua Catalana.

Bezezcky, T. 2013. The amphorae of Roman Ephesus (Forschungen in Ephesos XV/1). Vienna: Verlag der Österreichisches Akademie der Wissenschaften.

Blazquez Martínez, J.M., Domergue, C. and Sillieres, P. (eds) 2002. La Loba (Fuenteovejuna, province de Cordoue,
Espagne): la mine et le village minier antiques. Burdeaux: Ausonius.

Bonet Rosado, H., Fumadó Ortega, I., Aranegui Gascó, C., Vives-Ferrándiz Sánchez, J., Hassini, H. and Kbiri Alaui, M. 2005. La ocupación mauritana, in, C. Aranegui Gascó (ed.) Lixus 2. Ladera Sur. Excavaciones arqueologica marroco-españolas en la colonia fenicia. Campañas 2002-2003 (Sagvntvm Extra 6) : 87-140. Valencia: Universidad de Valencia.

Boube, J. 1979-1980. Amphores prérromaines trouvées en mer au voisinage de Rabat. Bulletin d'Archéologie Marocaine 12: 163-235.

Boube, J. 1987-1988. Les amphores de Sala à l'époque mauritanienne. Bulletin d'Archéologie Marrocaine 17: 183-208.

Brotons Yagüe, F. and Murcia Muñoz, A.J. 2014. Una guarnición tardorrepublicana romana en la cuenca alta de los ríos Argos y Quipar. El 'castellum' de Archivel y la 'turris' de Barranda (Caravaca - Región de Murcia), in F. Sala-Sellés and J. Moratalla Jávega (eds) Las guerras civiles romanas en Hispania: una revisión histórica desde la Contestania: 183-197. Alicante: Museo Arqueológico de Alicante-Universidad de AlicanteDiputación de Alicante.

Callu, J.-P., Morel, J-P., Rebuffat, R. and Hallier, G. 1965. Thamusida I (2eme supplément de Mélanges de l'École Française de Rome et Athénes). Paris: E. De Boccard.

Carandini, A. 1981. Sviluppo e crisi delle manifatture rurali e urbane, in Società romana e produzzione schiavistica II : 3-19. Roma-Bari : Laterza.

Carre, M.-B. and Mattioli, S.P. 2003. Tentativo di classificazione delle anfore olearie adriatiche. Aquileia Nostra LXXIV: 453-476.

Cerdá i Juan, D. 2000. Les Àmfores Salseres a le Illes Balears (Col-lecció La Deixa 4). Mallorca: Monografies de Patrimoni Històric del Consell de Mallorca.

Cipriano, M.-T. and Carre, M.-B. 1989. Production et typologie des amphores sur la côte adriatique de l'Italie, in Amphores Romaines et Histoire Économique: Dix Ans de Recherches. Actes du Colloque (Sienne, 22-24 mai 1986) (Collection de L'École Française de Rome 114): 67-104. Rome : École Française de Rome.

Chic García, G. and Garcia Vargas, E. 2004. Alfares y producciones cerámicas en la provincia de Sevilla, in D. Bernal Casasola and L. Lagóstena Barrios (eds) Actas del Congreso Internacional Figlinae Baeticae. Talleres Alfareros y Producciones Cerámicas en la Bética Romana (ss. II a.C. - VII d.C.) (Cádiz, 12-14 noviembre 2003) (British Archaeological Reports, International Series 1266): 279-348. Oxford: John and Erica Hedges Ltd.

Comas i Solá, M. 1985. Baetulo. Les Àmfores (Monografies Badalonines 8). Badalona: Museu de Badalona.

Conlin, E. and Ortiz, A. forthcoming. Actividad arqueológica preventiva en c/ Dr. Fleming 13-15 de Carmona (Sevilla), in Anuario Arqueológico de Andalucía 2007. Vol. III. Actividades de Urgencia. Sevilla: Junta de Andalucia.

Desbat, A. and Lemaître, S. 2000. Les premières importations d'amphores de Bétique à Lyon, in D. 
Bernal Casasola and E. García Vargas (eds), Actas del Congreso Internacional Ex Baetica Amphorae. Conservas, aceite y vino de la Bética en el Imperio Romano (Écija y Sevilla, 17-20 diciembre, 1998): Vol. 3, 793-815. Écija: Gráficas Sol.

Díaz García, M. and Otiña Hermoso, P. 2003. Valoración comercial de Tarraco: importaciones cerámicas entre el siglo III a.C. y la dinastía julio-claudia, in XXVII Congreso Nacional de Arqueología (Huesca, 6-8 maio 2003), Vol. III Mundo Clásico (Bolskan-Revista de Arqueología del Instituto de Estudios Aragoneses 20): 67-82. Huesca: Instituto de estudios Altoaragoneses.

Domergue, C. 1973. Belo-I. La stratigraphie (Publicaciones de la Casa de Velazquez 1). París: Casa de Velázquez.

Domergue, C. 1987. Catalogue des mines et des fonderies antiques de la Péninsule Ibérique. 2 vols. Madrid: Diffusion E. de Boccard.

Ehmig, U. 2007. Die römischen Amphoren im Umland von Mainz (Frankfurter Archäologische Schriften 5). Wiesbaden: Reichert Verlag.

Ehmig,U.2010.Dangstetten IV.Die Amphoren.Untersuchungen zur Belieferuq einer Militaranlage in augusteischer Zeit und den Grundlagen archaologischer Interpretation von Fund und Befund (Forschungen und Berichte zur vor-und Frithgeschichte in Baden-wurttemberg Band 117). Stuttgart : Konrad Theiss Verlag.

Étienne, R. and Mayet, F. 2004. L'huile hispanique. Corpus des timbres amphoriques sur amphores Dressel 20. Paris: Diffusion E. de Boccard.

Fabião, C. 1989. Sobre as ânforas do acampamento romano da Lomba do Canho (Arganil) (Cadernos da UNIARQ 1). Lisboa: Instituto Nacional de Investigação Científica.

Fabião, C. 1998. O Mundo Indígena e a sua Romanização na Área Céltica do Território Hoje Português. Unpublished PhD dissertation, Lisboa, Faculdade de Letras de Universidade de Lisboa.

Fabião, C. 2001. Sobre as mais antigas ânforas romanas da Baetica no Ocidente Peninsular, in D. Bernal Casasola and E. García Vargas (eds) Actas del Congreso Internacional Ex Baetica Amphorae. Conservas, aceite y vino de la Bética en el Imperio Romano (Écija y Sevilla, 1720 diciembre, 1998): Vol. 2, 665-682. Écija: Gráficas Sol.

Fabião, C. and Guerra, A. 1994. As ocupações antigas de Mesas do Castelinho (Almodôvar). Resultados preliminares das Campanhas de 1990-92, in Actas das $V$ Jornadas Arqueológicas da Associação dos Arqueólogos Portugueses (Lisboa,1993): 275-289. Lisboa: Associação dos Arqueólogos Portugueses.

Fabião, C., Guerra, A., Almeida, J., Almeida, R.R. de, Pimenta, J. and Filipe, V. 2016. Marcas de ânforas romanas na Lusitânia (do Museu Nacional de Arqueologia de Lisboa ao Museo Nacional de Arte Romano de Mérida) (Corpus Internationale des Timbres Amphoriques, Fascicule 19). Lisboa: Union Académique Internationale / Academia das Ciências de Lisboa / UNIARQ.

Fabião, C. and Almeida, R.R. de forthcoming. Las ánforas béticas en Lusitania. Veinte años después, in II Congreso Internacional Ex Baetica Amphorae. Veinte años después (Sevilla, 17-20 diciembre de 2018).
Fernández Cacho, S. 1995. Las industrias derivadas de la pesca en la provincia romana de la Bética: la alfarería de El Rinconcillo (Algeciras, Cádiz). Spal 4: 173-214.

Ferrer Albelda, E. y García Fernández, F.J. 2008. Cerámica turdetana, in D. Bernal Casasola and A. Ribera i Lacomba (eds) Cerámicas hispanorromanas. Un estado de la cuestión: 201-219. Cádiz: Servicio de Pubicaciones de la Universidad de Cádiz.

García Vargas, E. 1998. La Producción de Ánforas en la Bahía de Cádiz en Época Romana. (Siglos II a. C. - IV d. C.). Écija: Gráficas Sol.

García Vargas, E. 2001. La producción de ánforas 'romanas' en el sur de Hispania. República y Alto Império, in D. Bernal Casasola and E. García Vargas (eds) Actas del Congreso Internacional Ex Baetica Amphorae. Conservas, aceite y vino de la Bética en el Imperio Romano (Écija y Sevilla, 17-20 diciembre, 1998): Vol. 1, 57-174. Écija: Gráficas Sol.

García Vargas, E. 2003a. Las producciones de la figlina. Ánforas, in A. Vázquez Labourdette (ed.) Arqueología y Rehabilitación en el Parlamento de Andalucía. Investigaciones Arqueológicas en el Antiguo Hospital de las Cinco Llagas de Sevilla: 200-219. Sevilla: Parlamento de Andalucía.

García Vargas, E. 2003b. La industria alfarera en el Bajo Guadalquivir en época romana, in A. Vázquez Labourdette (ed.) Arqueología y Rehabilitación en el Parlamento de Andalucía. Investigaciones Arqueológicas en el Antiguo Hospital de las Cinco Llagas: 124-138. Sevilla: Parlamento de Andalucía.

García Vargas, E. 2009. Las ánforas republicanas de Hispalis (Sevilla) y la 'cristalización' del repertorio anfórico provincial, in R. Cruz-Auñon Briones and E. Ferrer Albelda (eds) Estudios de Prehistoria y Arqueología en Homenaje a Pilar Acosta Martínez: 437-464. Sevilla: Servicio de Publicaciones de la Universidad de Sevilla.

García Vargas, E. 2010. Formal Romanisation and Atlantic projection of amphorae from the Guadalquivir Valley, in C. Carreras Monfort and R. Morais (eds) The Western Roman Atlantic Façade. A study of the economy and trade in the Mar Exterior from the Republic to the Principate (British Archaeological Reports, International Series 2162): 55-65. Oxford: Archaeopress.

García Vargas, E. 2012. Producciones anfóricas tardorrepublicanas y tempranoaugusteas del valle del Guadalquivir. Formas y ritmos de la romanización en Turdetania a través del artesanado cerámico, in D. Bernal Casasola and A. Ribera i Lacomba (eds) Cerámicas hispanorromanas II. Producciones regionales: 177-206. Cádiz: Servicio de Publicaciones de la Universidad de Cádiz.

García Vargas, E. 2016. Pellicer D (Valle del Guadalquivir), in Amphorae ex Hispania. Paisajes de producción y de consumo, viewed 17 september 2017, <http://amphorae.icac.cat/amphora/pellicer-dguadalquivir-valley>.

García Vargas, E., Almeida, R.R. de and Fabião, C. forthcoming. El deposito de Itálica y el comercio en el valle del Baetis en el tercio central del siglo I a.C. 
García Vargas, E., Almeida, R.R. de and González Cesteros, H. 2011. Los tipos anfóricos del Guadalquivir en el marco de los envases hispanos del siglo I a.C. Un universo heterogéneo entre la imitación y la estandarización. Spal 20: 185-284.

García Vargas, E., Almeida, R.R. de and González Cesteros, H. 2016a. Ovoide 4 (Valle del Guadalquivir), in Amphorae ex Hispania. Paisajes de producción y de consumo, viewed 20 september 2017, <http://amphorae.icac.cat/ amphora/ovoid-4-guadalquivir-valley>.

García Vargas, E., Almeida, R.R. de and González Cesteros, H. 2016b. Ovoide 5 (Valle del Guadalquivir), in Amphorae ex Hispania. Paisajes de producción y de consumo, viewed 23 september 2017, <http://amphorae.icac.cat/ amphora/ovoid-5-guadalquivir-valley>.

García Vargas, E., Almeida, R.R. de and González Cesteros, H. 2016c. Ovoide 6 (Valle del Guadalquivir), in Amphorae ex Hispania. Paisajes de producción y de consumo, viewed 28 september 2017, < http://amphorae.icac.cat/ amphora/ovoid-6-guadalquivir-valley>.

García Vargas, E. and López Rosendo, E. 2008. El alfar de Rabatún (Jerez de la Frontera, Cádiz) y la producción de ánforas y cerámica común en la campiña del Guadalete en época altoimperial romana. Spal 17: 281-313.

Gauthier, B. and Joncheray, J.P. 1993. Le gisement C du Cap Gros. Cahiers d'Archéologie Subaquatique XII: 167-183.

Gebelli í Borras, P. and Díaz García, M. 2001. Importaciones béticas en Tarraco en contextos pre-augusteos, in D. Bernal Casasola and E. García Vargas (eds) Actas del Congreso Internacional Ex Baetica Amphorae. Conservas, aceite y vino de la Bética en el Imperio Romano (Écija y Sevilla, 17-20 diciembre, 1998): Vol. 3, 1349-1355. Écija: Gráficas Sol.

Giacobbi, M. and Lequément, M.-F. 1987. La céramique de l'épave de Fos 1. Archaeonautica 7:167-191.

Gil de los Reyes, M. S., Gómez Saucedo, Mª T. and Rodríguez Rodríguez, I. 1990. El espacio extramuros de Carmona romana (Sevilla) y su uso industrial: el horno de la C/ Doctor Fleming $\mathrm{n}^{\circ}$ 25, in Anuario Arqueológico de Andalucía 1987. Vol. III. Actividades de Urgencia: 586-590. Sevilla: Junta de Andalucía.

Gómez Saucedo, Ma T. 2009. Actividad arqueológica preventiva en c/ Montánchez $\mathrm{n}^{\circ} 15$ de Carmona (Sevilla). Anuario Arqueológico de Andalucía 2004. Vol. III. Actividades de Urgencia, pp. 3101-3114. Sevilla: Junta de Andalucía.

Gómez Saucedo, Mª . T. forthcoming. Actividad arqueológica preventiva en c/ González Parejo noㅡㄴ 19 A de Carmona (Sevilla), in Anuario Arqueológico de Andalucía 2008. Vol. III. Actividades de Urgencia. Sevilla: Junta de Andalucía.

González Cesteros, H. 2013. Ánforas del foro tardorrepublicano de Valeria, in D. Bernal Casasola, L.C. Juan, M. Bustamante Álvarez, J.J. Díaz Rodríguez and A.M. Sáez Romero (eds) Hornos, talleres y focos de producción alfarera en Hispania. Actas del I Congreso Internacional de la SECAH (Cádiz, 3-4 marzo 2011) (Monografías Ex Officina Hispana, 1): 127-143. Cádiz: Servicio de Publicaciones de la Universidad de Cádiz.
González Cesteros, H. 2014. Ánforas Hispanas en la Germania Inferior antes de la Formación de la Provincia (20 a.C.-69 d.C.), Unpublished PhD dissertation, Tarragona, Universitat Rovira i Virgili.

González Cesteros, H. 2015. Hallazgos de productos tarraconenses en la frontera germana. Un mercado secundario, in V. Martínez Ferreras (ed.) La difusión comercial de las ánforas vinarias de Hispania CiteriorTarraconensis (s. I a.C.-I d.C) (Archeopress Roman Archaeology 4): 205-220. Oxford: Archaeopress.

González Cesteros, H. and Almeida, R.R. de 2017. Chapter 3. Amphorae from the West: Hispania (Spain and Portugal). Las ánforas de aceite de oliva béticas. De las Oberaden 83 hasta las Dressel 20 en el Kops Plateau de Nimega, in C. Carreras Monfort and J. Van den Berg (eds) Amphorae from the Kops Plateau (Nijmegen): trade and supply to the Lower-Rhineland from the Augustan period to AD 69/70 (Archeopress Roman Archaeology 20): 47-60. Oxford: Archaeopress.

González Cesteros, H., Almeida, R.R. de and García Vargas, E. 2016. Ovoide 1 (Valle del Guadalquivir), in Amphorae ex Hispania. Paisajes de producción y de consumo, viewed 5 september 2017, < http://amphorae.icac.cat/ amphora/ovoid-1-guadalquivir-valley>.

González Cesteros, H. and Berni Millet, P. 2018. Roman amphorae in Neuss. Augustan to Julio-Claudian contexts (Roman and Late Antique Mediterranean Pottery 12). Oxford: Archaeopress.

González Cesteros, H., García Vargas, E. and Almeida, R. R. de 2016a. Haltern 71 (Valle del Guadalquivir), in Amphorae ex Hispania. Paisajes de producción y de consumo, viewed 2 october 2017, <http://amphorae. icac.cat/amphora/dressel-28-baetica-coast>.

González Cesteros, H., García Vargas, E. and Almeida, R.R. de 2016b. Oberaden 83 (Valle del Guadalquivir), in Amphorae ex Hispania. Paisajes de producción y de consumo, viewed 20 september 2017, <http://amphorae.icac. cat/amphora/oberaden-83-guadalquivir-valley>.

González Cesteros, H., García Vargas, E. and Almeida, R.R. de 2018. Análisis de caso: las ánforas ovoides de la Hispania Tardorrepublicana, in R. Járrega Domínguez (coord.) Estudios sobre ánforas hispanas (Ex Officina Hispania. Cuadernos de la SECAH 3): 81-112. Madrid: Ediciones La Ergástula.

González Cesteros, H. and Tremmel, B. 2011-2012. Aceite, vino y salazones hispanos en Oberaden, in J.M. Noguera Celdrán (ed.) De vino et oleo Hispaniae. Áreas de producción y procesos tecnológicos del vino y el aceite en la Hispania romana (Murcia, 5-7 mayo 2010) (Anales de Prehistoria y Arqueología de la Universidad de Murcia 27-28): 527-542. Murcia: Universidad de Murcia.

González Tobar, I. and Berni Millet, P. 2018. El Bombo. Posible centro productor de ánforas Ovoide 5 en el territorio ribereño de Córdoba. Boletín Ex Officina Hispana 9: 9-11.

González Tobar, I. and Mauné, S. 2018. Un atelier rural inédit d'amphores à huile augusto-tibériennes à Fuente de los Peces (Fuente Palmera, province de Cordoue). Mélanges de la Casa de Velázquez 48, 2: 203-234. 
González Tobar, I, Mauné, St., Tiago-Seoane, O, García Vargas, E and Levêque, F. 2019. L'Atelier de'amphores Dressel 20 et Haltern 70 d'El Mohíno à Palma del Río (prov. Cordoue, Espagne), in SFECAG. Actes du Congrès de Reims (Reims, 10-13 mai 2018): 319-344. Marseille: SFECAG.

Guerrero Ayuso, V.M. 1987. La colonia de Sant Jordi (Mallorca). Estudis d'Arqueologia i Epigrafia. Palma de Mallorca: Publications del Centre d'Estudis Gabriel Alomar.

Hernández Hernández, F. 1993. El yacimiento de Villasviejas y el proceso de romanización, in El proceso histórico de la Lusitania Oriental en época prerromana y romana (Cuadernos Emeritenses 7): 113-144. Mérida: Museo Nacional de Arte Romano.

Hesnard, A. 1980. Un dépôt augustéen d'amphores à la Longarina, Ostie, in Memoirs of the American Academy in Rome XXXVI: 141-163. Ann Arbor: University of Michigan Press.

Hesnard, A., Ricq, M., Arthur, P., Picon, M. and Tchernia, A. 1989. Aires de production des gréco-italiques et des Dr.1, in Amphores Romaines et Histoire Économique: Dix Ans de Recherches. Actes du Colloque (Sienne, 22-24 mai 1986) (Collection de L'École Française de Rome 114): 21-65. Rome : École Française de Rome.

Izquierdo Peraille, I., Kbiri Alaui, M., Bonet Rosado, H. and Milou, B. 2001. Las fases púnico-mauritanas I (175-150 a 80/50 a.C) y II (80/50 a.C.-15 d.C.), in C. Aranegui Gascó (ed.) Lixus. Colonia Fenicia y Ciudad Púnico-mauritana. Anotaciones sobre su ocupación medieval (Sagvntvm Extra 4): pp. 141-168. Valencia: Universidad de Valencia.

Lamboglia, N. 1955. Sulla cronologia delle amphore romane di etá republicane (II-I secolo a.C.). Revista de Studi Liguri 22: 243-295.

Lagóstena Barrios, L. 1996. Alfarería romana en la Bahía de Cádiz. Cádiz: Servicio de Publicaciones de la Universidad de Cádiz.

Lagóstena Barrios, L. 2004. Las ánforas salsarias de Baetica. Consideraciones sobre sus elementos epigráficos, in J. Remesal Rodríguez (ed.) Epigrafía anfórica (Col.leció Instrumenta 17): 197-219. Barcelona: Publicacions i Edicions Universitat de Barcelona.

Lagóstena Barrios, L. and Bernal Casasola, D. 2004. Alfares y producciones cerámicas en la provincia de Cádiz. Balance y perspectivas, in D. Bernal Casasola and L. Lagóstena Barrios (eds) Figlinae Baeticae: talleres alfareros y producciones cerámicas en la Bética romana (ss. II a.C.-VII d.C.): Actas del Congreso Internacional (Cádiz, 12-14 noviembre 2003) (British Archaeological Reports, International Series 1266): 39-123. Oxford: John and Erica Hedges Ltd.

Lemaître, S., Desbat, A. and Maza, G. 1998. Les amphores $\mathrm{du}$ site $\mathrm{du}$ 'sanctuaire de Cybèle' à Lyon. Étude préliminaire. SFECAG Actes du Congrès d'Istres (Istres, 2124 mai 1998): 45-59. Marseille: SEFCAG.

Lillo Carpio, P. 1986. Habitats singulares en la Edad Antigua. La Cueva de Las Peñas Blancas en las Lomas de la Carrasca (Cartagena). Anales de Prehistoria y Arqueología 2: 121-129.
Liou, B. 1987. L'exportation du vin de Tarraconaise d'aprés les épaves, in El Vi a l'Antiguitat: Economia, Producció i Comerç al Mediterrani Occidental. Actes du I Colloqui d'Arqueologia Romana (Badalona, 6-9 Maig 1985) (Monografies Badalonines 9): 271-284. Badalona: Museu de Badalona.

Liou, B. 2001. Las ánforas béticas en el mar. Les épaves en Méditerranée à cargaison d'amphores de Bétique, in D. Bernal Casasola and E. García Vargas (eds) Actas del Congreso Internacional Ex Baetica Amphorae. Conservas, aceite y vino de la Bética en el Imperio Romano (Écija y Sevilla, 17-20 diciembre, 1998): Vol. 3, 1061-1111. Écija: Gráficas Sol.

Liou, B. and Pomey, P. 1985. Informations Archéologiques. Direction des Recherches Archéologiques SousMarines. Gallia 43.2: 547-576.

López Rosendo, E. 2008. El alfar romano altoimperial del Jardín de Cano (El Puerto de Santa María, Cádiz, España), en el contexto económico de 'Gades'. Revista de Historia de El Puerto 41: 39-74.

López Rosendo, E. 2010. Los talleres alfareros del Jardín de Cano (El Puerto de Santa María, Cádiz). La producción anfórica de Gades en torno al cambio de era, in Rei Cretariae Romanae Fautorum Acta 41: 411-419.

Loeschcke, S. 1909. Ausgrabungen bei Haltern. Die Keramische Funde (Mitteilungen der Altertums-Kommission für Westfalen 5). Münster: Verein für Geschichte und Altertumskunde.

Loeschke, S. 1942. Die römische und die belgische Keramik, in C. Albrecht (ed.) Das Römerlager in Oberaden und das Uferkastell in Beckinghausen an der Lippe. Bd. II, Hft. 2, Die römische und die belgische Keramik, Die Gegenstände aus Metall: 7-148. Dortmund: Verlag Fr. Wilh. Ruhfus.

Manacorda, D. and Pallecchi, S. (eds) 2012. Le fornaci di Giancola a Brindisi. Bari: Edipuglia.

Marlière, E. 2002. L'outre et le tonneau dans l' Occident romain (Monographies Instrumentum 22). Montagnac : Éd. Mergoil.

Márquez Villora, J. C. and Molina Vidal, J. 2001. El Comércio en el Territorio de Ilici. Epigrafía, importación de alimentos y relación com los mercados mediterráneos. Alicante: Publicaciones de la Universidad de Alicant.

Martin-Kilcher, S. 1987. Die römischen Amphoren aus Augst und Kaiseraugst. Vol. I. Augst: Amt für Museen und Archäologie des Kantons Basel-Landschaf.

Martin-Kilcher, S. 1994. Die römischen Amphoren aus Augst und Kaiseraugst. Vols. II y III. Augst: Amt für Museen und Archäologie des Kantons Basel-Landschaf.

Martin-Kilcher, S. 1999. Colaboration in C. Schucany, L. Berger and D. Paunier (eds) Römische Keramik in der Schweiz (Antiqua 31). Basel: Daniel Paunier (Hrsg.).

Martin-Kilcher, S. 2003. Wein, Olivenöl, Fischsauce. Amphoren aus den stratifizierten Befunden der 1. und 2. Holzbauperiode, in Zur Frühzeit von Vindonissa: 351360. Brugg: Gesselschaft Pro Vindonissa.

Martin-Kilcher, S. 2004. Fischsaucen: Pinselaufschriften und römisch Amphoren, in J. Remesal Rodríguez (ed.) Epigrafía anfórica (Col.leció Instrumenta 17): 245-257. Barcelona: Publicacions i Edicions Universitat de Barcelona. 
Martín Menéndez, A. 2008. Àmfores tarraconenses i bétiques em els dereclites de mitjan segle I a.C. a la costa catalana, in SFECAG. Actes du congrès de l'EscalaEmpúries. Les productions céramiques en Hispanie Tarraconaise (IIe siècle avant J.-C-VIe siècle après J.-C) (l'Escala-Empúries, 1-4 mai 2008): 103-127. Marseille: SFECAG.

Martínez Maganto, J. 2001. Inscripciones sobre ánforas de salazón: interpretación sobre la estructura y significado comercial de los tituli picti, in D. Bernal Casasola and E. García Vargas (eds) Actas del Congreso Internacional Ex Baetica Amphorae. Conservas, aceite y vino de la Bética en el Imperio Romano (Écija y Sevilla, 1720 diciembre, 1998): Vol. 4, 1206-1220. Écija: Gráficas Sol.

Mas García, J. 1985. Excavaciones en el yacimiento submarino de San Ferreol, in VI Congreso Internacional de Arqueología Submarina (Cartagena, 1982): 189-224. Madrid: Ministerio de Cultura, Dirección General de Bellas Artes y Archivos.

Mataloto, R. 2008. O Castelo dos Mouros (Graça do Divor, Évora): a arquitectura 'ciclópica' romana e a romanizaçao dos campos de 'Liberalitas Iulia Ebora'. Revista Portuguesa de Arqueologia vol. 11, nำ: 123-147.

Mataloto, R., Williams, J. and Roque, R. 2016. Amphorae at the origins of Lusitania: transport pottery from Western Hispania Ulterior in Alto Alentejo, in I.V. Pinto, R.R. de Almeida and A. Martin (eds) Lusitanian Amphorae. Production and Distribution (Roman and Late Antique Mediterranean Pottery 10): 139-152. Oxford, Archaeopress.

Mateo Corredor, D. 2016. Comercio anfórico y relaciones mercantiles en Hispania Ulterior (ss. II a.C.-II d.C.) (Col. leció Instrumenta 52). Barcelona: Publicacions i Edicions Universitat de Barcelona.

Mateo Corredor, D. and Mayorga Mayorga, J.F. 2017. Comercio anfórico tardorrepublicano en Malaca: las importaciones de calle Beatas-esquina Ramón Franquelo (Málaga, España). Sagvntvm 49: 103-122.

Mauné, S., García Vargas, E., Bourgeon, O., Corbeel, S., Carrato, C., García-Dils, S., Bigot, F. and Vázquez Paz, J. 2014. L'atelier d'amphores à huile Dr. 20 de Las Delicias à Écija (Prov. de Séville, Espagne), in SFECAG, Actes du congrès de Chartres (Chartres, 29 mai-1er juin 2014): 419-444. Marseille: SFECAG.

Mercando, L. 1975-81. Relitto di nave romana presso Ancona. Forma Maris Antiqui 11-12: 69-78.

Miró i Canals, J. 2016. Tarraconense 1 (área costera noreste tarraconense), in Amphorae ex Hispania. Paisajes de producción y de consumo, viewed september 2017, <http://amphorae.icac.cat/amphora/tarraconense1-tarraconensis-northern-coastal-area>.

Molina Vidal, J. 1995. Las ánforas Lomba do Canho 67. Aportaciones al estudio de un nuevo tipo: difusión y valoración económica, in Actas del XXII Congreso Nacional de Arqueología (Vigo, 2993): 419-424. Vigo: Xunta de Galicia.

Molina Vidal, J. 1997. La dinámica comercial romana entre Italia e Hispania Citerior. Alicante: Instituto de Cultura Juan Gil- Albert.
Molina Vidal, J. 2001. Las primeras exportaciones béticas en el Mediterráneo occidental, in D. Bernal Casasola and E. García Vargas (eds) Actas del Congreso Internacional Ex Baetica Amphorae. Conservas, aceite y vino de la Bética en el Imperio Romano (Écija y Sevilla, 1720 diciembre, 1998): Vol. 2, 637-645. Écija: Gráficas Sol.

Morais, R. 2010. Capítulo 7.5: Ânforas, in J. Alarcão, P. Carvalho and A. Gonçalves (coord) Castelo da LousaIntervenções Arqueológicas de 1997 a 2002 (Stvdia Lvsitana 5): 181-218. Mérida: Museo Nacional de Arte Romano / Edia.

Morín de Pablos, J., Almeida, R.R. de, Barroso Cabrera, R. and López Fraile, F. 2010. El yacimiento de Pozo Sevilla (Alcázar de San Juan, Ciudad Real) ¿Un ejemplo de casa torre en la Mancha?, in V. Mayoral Herrera and S. Celestino Pérez (ed.) Los paisajes rurales de la romanización: arquitectura y explotación del territorio (Museo Arqueológico Provincial de Badajoz, 27 y 28 de octubre de 2008): 287-322. Madrid: Ediciones Ergástula.

Niveau de Villedary y Mariñas, A.M. and Blanco Jiménez, F.J. 2007. Continuidad púnica en la Gades republicana. La producción vascular del horno de la calle Troilo. Spal 16: 195-224.

Nolla Brufau, J.-M. 1974. Las ánforas romanas de Ampurias. Ampurias 36-37: 147-197.

Palazzo, P. 1988. Aspetti tipologici della produzione di anfore brindisine, in C. Marango (a cura di) La Puglia in età republicana: 109-117. Galatina: Congedo Editore.

Palazzo, P. 1989. Le anfore di Apani (Brindisi), in Amphores Romaines et Histoire Économique: Dix Ans de Recherches. Actes du Colloque (Sienne, 22-24 mai 1986) (Collection de L'École Française de Rome 114): 548-553. Rome : École Française de Rome.

Palazzo, P. 2013. Le anfore di Apani (Brindisi). Roma: Scienze e Lettere.

Panella, C. 1973. Appunti su un gruppo di anfore della prima, media e tarda età Imperiale, in Ostia III: Le terme del Nuotatore: scavo dell'ambiente V et di un saggio dell'area (Studi Miscellanei 21): 460-633. Roma: De Luca.

Parreira,J.C. 2009. As ânforas romanas de Mesas do Castelinho, Unpublished Master dissertation, Lisboa, Faculdade de Letras da Universidade de Lisboa, <repositorio.ul.pt/ bitstream/10451/446/1/21415_ulfl071253_tm.pdf>.

Pascual Berlanga, G. and Ribera i Lacomba, A. 2001. El consumo de productos béticos en Valentia y su entorno: la continuidad de una larga tradición, in D. Bernal Casasola and E. García Vargas (eds) Actas del Congreso Internacional Ex Baetica Amphorae. Conservas, aceite y vino de la Bética en el Imperio Romano (Écija y Sevilla, 17-20 diciembre, 1998): Vol. 2, 565-576. Écija: Gráficas Sol.

Peacock, D.P.S. and Williams, D.F. 1986). Amphorae and the roman economy. An Introductory Guide. London: Longman.

Pellicer Catalán, M. 1978. Tipología y cronología de las ánforas prerromanas del Guadalquivir según el Cerro Macareno (Sevilla). Habis 9: 365-400.

Pellicer Catalán, M., Escacena Carrasco, J. L. and Bendala Galán, M. 1983. El Cerro Macareno (Excavaciones 
Arqueológicas en España 124). Madrid: Ministerio de Cultura.

Pérez Macías, J. A. and Delgado Domínguez, A. 2007. Los metalla de Riotinto en época julio-claudia, in J.A. Pérez Macías and A. Delgado Domínguez (eds) Las minas de Riotinto en época julio-claudia: 37-183. Huelva: Universidad de Huelva / Fundación Riotinto.

Pérez Suñé, J.M. and Revilla Calvo, V. 2001. Las producciones béticas y el consumo urbano: Iluro y su territorio, in D. Bernal Casasola and E. García Vargas (eds) Actas del Congreso Internacional Ex Baetica Amphorae. Conservas, aceite y vino de la Bética en el Imperio Romano (Écija y Sevilla, 17-20 diciembre, 1998): Vol. 2, 593-605. Écija: Gráficas Sol.

Pesavento Mattioli, S. and Carre, M.-B. 2009. Olio e Pesce in epoca romana. Produzione e commercio nelle regioni dell'Alto Adriatico. Roma: Quasar.

Pimenta. J., Henriques, E. and Mendes, H. 2012. O acampamento romano do Alto dos Cacos, Almeirim. Almeirim: Câmara Municipal de Almeirim.

Pimenta, J. and Mendes, H. 2014. Monte dos Castelinhos - Vila Franca de Xira. Um sítio singular para o estudo da romanizaçāo do vale do Tejo, in E. Salas Tovar (dir.) and R. Mataloto, V. Mayoral Herrera and C. Roque (eds) La gestación de los paisajes rurales entre la história y el período romano. Formas de asentamiento y procesos de implantación (Anejos de Archivo Español de Arqueología LXX): 125-142. Madrid: Consejo Superior de Investigaciones Científicas.

Pimenta, J., Mendes, H. and Norton, J. 2008. O povoado tardo-republicano do Monte dos Castelinhos - Vila Franca de Xira. Al-Madam II Série 16: 26-37.

Ramon Torres, J. 1995. Las ánforas fenicio-púnicas del Mediterráneo centraly occidental (Col.lecció Instrumenta 2). Barcelona: Publications i Edicions Universitat de Barcelona.

Revilla Calvo, V. 2010. Cultura material y poblamiento en el territorio de Tarraco: los contextos cerámicos de la villa del Vilarenc (Calafell), in V. Revilla Calvo and M. Roca Roumens (eds) Contextos ceràmics i cultura material d'època augustal a l'occident romà (Barcelona, 15-16 abril 2007): 198-220. Barcelona: Universitat de Barcelona / Institut Català d'arqueologia clàssica / Museu d'arqueologia de Catalunya-Empúries.

Riberai Lacomba,A.2010. Los materiales de época augustea de Valentia: símbolo de una etapa precaria o muestra del inicio del renacer de la ciudad, in V. Revilla Calvo and $\mathrm{M}$. Roca Roumens (eds) Contextos ceràmics i cultura material d'època augustal a l'occident romà (Barcelona, 15-16 abril 2007): 262-292. Barcelona: Universitat de Barcelona / Institut Català d'arqueologia clàssica / Museu d'arqueologia de Catalunya-Empúries.

Ribera i Lacomba, A. and Ripollés Alegre, P.P. 1977. Ánforas de Benicarló y su zona costera. Cuadernos de Prehistoria y Arqueologia Castellonenses 4: 159-174.

Rodríguez Almeida, E. 1984. Il Monte Testaccio: ambiente, storia, materiali. Roma: Quasar.

Ruiz Blanco, D. 2017. Ánforas Republicanas del Valle del Guadalquivir en el Patio de Banderas. Estudio cronológico, tipológico y funcional, Unpublished Master dissertation, Universidad de Sevilla.

Rodríguez Rodríguez, I. 2001. Las áreas artesanales. Los alfares, in A. Caballos Rufino (ed.) Carmona Romana: 425-438. Sevilla: Ayuntamiento de Carmona / Servicio de Publicaciones de la Universidad de Sevilla.

Ruiz de Arbulo, J, Mar, R., Roca Roumens, M. and Díaz Avellaneda, M. 2010. Un contexto cerámico de fines del siglo I a.C. como relleno constructivo de un almacén portuario localizado bajo el teatro de Tarragona, in V. Revilla Calvo and M. Roca Roumens (eds) Contextos ceràmics $i$ cultura material d'època augustal a l'occident romà (Barcelona, 15-16 abril 2007): 220-260. Barcelona: Universitat de Barcelona / Institut Català d'arqueologia clàssica / Museu d'arqueologia de Catalunya-Empúries.

Sanchez, C. 2009. Narbonne à l'époque tardo-républicaine: Chronologies, commerce et artisanat céramique (Revue archéologique de Narbonnaise Supplément 38). Montpellier: Editions de l'Association de la Revue archéologique de Narbonnaise.

Sáez Fernández, P., Tinoco Muñoz, J., García Vargas, E. and García Dils de la Vega, S. 2001. Excavación arqueológica de urgencia en el alfar romano Las Delícias (Écija, Sevilla), in Anuario Arqueológico de Andalucía 1997. Vol. III: 562-575. Sevilla: Junta de Andalucia.

Sáez Romero, A.M. 2008. La producción de ánforas en el área del Estrecho en época tardopúnica (siglos III-I a.C.), in D. Bernal Casasola, D. and A. Ribera i Lacomba (eds) Cerámicas hispanorromanas. Un estado de la cuestión: 635-660. Cádiz: Servicio de Publicaciones de la Universidad de Cádiz.

Sáez Romero, A.M., Bernal Casasola, D., García Vargas, E. and Díaz Rodríguez, J. J. 2016. Ramon T-7.4.3.3 (Costa Bética), in Amphorae ex Hispania. Paisajes de producción $y$ de consumo, viewed 10 september 2017, <http:// amphorae.icac.cat/amphora/ramon-t-7433-baeticacoast>.

Sáez Romero, A.M., González Cesteros, H. and HiguerasMilena Castellano, A. 2016. Una aportación al estudio del comercio marítimo antiguo gaditano a partir de un conjunto de ánforas halladas en águas del área de La Caleta (Cádiz). Onoba. Revista de Arqueología y Antigüedad: 69-103.

Schönberger, H. and Simon, H-G. 1976. Das augusteische Römerlagern Rödgen. Die Funde aus dem Frühkaiserzeitlichen Lagern Rödgen, Friedberg und Bad Nauheim (Limesforschungen XV). Berlín: Gebr. Mann Verlag.

Silva, A. 2008. Vivre au-dela du fl euve de l'oubli. Portrait de la communauté villageoise du Castro do Vieito (estuaire do Rio Lima, NO du Portugal), au moment de l'intégration du NO de la péninsule ibérique dans l'orbis romanum, Unpublished Phd dissertation, Coimbra, Faculdade de Letras da Universidade de Coimbra.

Stefano, A. de 2008. Un contesto ceramico di età repubblicana e primo/medio imperiale dall'area delle due domus, in Herdonia X, Ricerche Archeologice a Herdonia: 45-144. Puglia: Edipuglia. 
Tabales Rodríguez, M.A. 2003. El complejo alfarero localizado bajo el Parlamento de Andalucía, in A. Vázquez Labourdette (ed.) Arqueología y Rehabilitación en el Parlamento de Andalucía. Investigaciones Arqueológicas en el Antiguo Hospital de las Cinco Llagas de Sevilla: 139-162. Sevilla : Parlamento de Andalucía.

Tabales Rodríguez, M.A. 2015. Excavaciones arqueológicas en el Patio de Banderas. Alcázar de Sevilla. Memoria de investigación (2009-2014), Unpublished cientifical report, Sevilla, Patronato del Real Alcázar y Casa Consistorial de Sevilla.

Tailliez, C. 1961. Travaux de l'été 1958 sur l'épave du 'Titan', à l'Ile du Lévant (Toulon), in Atti del II Congresso Internazionale di Archeologia Sottomarina (Albenga, 1958): 175-198. Bordighera: Instituto Internazionale di Studi Liguri / Museo Bicknell.

Tchernia, A. 1969. Informations archéologiques. Direction des recherches sous-marines. Gallia 27: 465-499.

Tchernia, A. 1986. Le Vin de l'Italie Romaine. Essai d'Histoire Economique d'Aprés les Amphores. Paris : École Française de Rome.

Tchernia, A. 1990. Contre les épaves, in A. Duval, J.P. Morel and Y. Roman (eds) Gaule Interne et Gaule Méditerranéenne aux IIe et Ier Siècles avant J.-C. Confrontations et Chronologies (Revue Archéologique Narbonnaise Sup. 21): 291-301. Paris: Éditions du Centre National de la Recherche Scientifique.

Toniolo, A. 1991. Le anfore di Altino (Archeologia Veneta 14). Padova: Società Archeologia Veneta.

Toniolo, A. 1996. Anfore, in A. M. Tamassia (ed.) Archeologia di un Ambiente Padano. S. Lorenzo di Pegognaga (Mantova): 235-270. Pegognaga: Soprintendenza archeologica della Lombardia.

Toniolo, A. 2000. Le anfore di Adria (IV-II secolo a.C.). Venezia: Sottomarina Libreria.

Tremoleda i Trilla, J. and Castanyer i Masoliver, P. 2013. Las ánforas republicanas itálicas de Catalunya (siglos III-I a. C.): estado de la cuestión, in F. Olmer (ed.) Itinéraires des vins romains en Gaule, IIIe-Ier siècles avant J.-C. Confrontation de facies (Lattes, 30 janvier - 2 février 2009) (Monographies d'Archéologie Méditerranéenne 5): 213-256. Lattes: Association pour le Développement de l'Archéologie en Languedoc-Roussillon (ADAL), Centre de Documentation Archéologique Régionale.

Vázquez Paz, J. and García Vargas, E. 2014. Imitaciones béticas de sigillata: contextos del s. I a.C.- I d.C. en la Plaza de la Encarnación y el Patio de Banderas del Real Alcázar de Sevilla, in F.J. García Fernández and E. García Vargas (eds) Comer a la moda. Imitaciones de vajilla de mesa en Turdetania y la Bética occidental durante la Antigüedad (s. VI a.C. - VI d.C.) (Col.lecció Instrumenta 46): 301-321. Barcelona: Publicacions i Edicions Universitat de Barcelona.

Viegas, C. 2011. A ocupacão romana do Algarve. Estudo do povoamento e economia do Algarve central e oriental no período romano (Estudos and Memórias 3). Lisboa: Centro de Arquologia da Universidade de Lisboa / FCT.

Werff, J. H. van den 1984. Roman Amphoras at Nijmegen - a Preliminary Report. Berichten van de Rijksdienst voor het Oudheidkundig bodemonderzoek 34: 347-381. 